\begin{abstract}
UNIVERSIDADE DE SÃO PAULO
FACULDADE DE ECONOMIA, ADMINISTRAÇÃO E CONTABILIDADE DEPARTAMENTO DE ADMINISTRAÇÃO

PROGRAMA DE MESTRADO PROFISSIONAL EM EMPREENDEDORISMO
\end{abstract}

Alessandra Bizeray Benedito Katz

O DESENVOLVIMENTO DE MODELO DE NEGÓCIOS EM EMPRESA STARTUP BRASILEIRA DE BIOTECNOLOGIA.

SÃO PAULO

2018 
Prof. Dr. Vahan Agopyan

Reitor da Universidade de São Paulo

Prof. Dr. Fabio Frezzati

Diretor da Faculdade de Economia, Administração e Contabilidade

Prof. Dr. Moacir Miranda de Oliveira Junior

Chefe do Departamento de Administração

Prof. Dr. Marcelo Caldeira Pedroso

Coordenador do Programa de Mestrado Profissional em Empreendedorismo 


\section{O DESENVOLVIMENTO DE MODELO DE NEGÓCIOS EM EMPRESA STARTUP BRASILEIRA DE BIOTECNOLOGIA}

Dissertação apresentada à coordenação do Programa de Mestrado Profissional em Empreendedorismo da Faculdade de Economia, Administração e Contabilidade da Universidade de São Paulo para obtenção do título de Mestre em Ciências.

Área de concentração: Empreendedorismo

Orientador: Prof. Dr. Marcelo Caldeira Pedroso

\section{Versão Corrigida}

São Paulo 
Katz, Alessandra Bizeray Benedito.

O desenvolvimento de modelo de negócios em empresa startup brasileira de biotecnologia / Alessandra Bizeray Benedito Katz. - São Paulo, 2018.

$128 \mathrm{p}$

Dissertação (Mestrado) - Universidade de São Paulo, 2019.

Orientador: Marcelo Caldeira Pedroso.

1. modelo de negócios. 2. startup. 3. biotecnologia. I. Universidade de São Paulo. Faculdade de Economia, Administração e Contabilidade. II. Título. 
Ao John, meu companheiro de viagem. À minha família e amigos, meu suporte. 



\section{AGRADECIMENTOS}

Ao Prof. Dr. Marcelo Caldeira Pedroso, pela jornada e orientação.

Aos professores do MPE pelo compartilhamento de conhecimento, e apoio, no decorrer do o curso, especialmente Prof. Dr. Martinho Isnard Ribeiro de Almeida e Profa Dra. Liliam Sanchez Carrete.

À especial e unida T3, \#tmjT3.

À Fabiana Caseiro pelo seu comprometimento, "vestir a camisa" do programa e pelo carinho com todos nós.

À todos que de alguma forma contribuíram para esse trabalho. 



\section{RESUMO}

\section{KATZ, A. B. B. O desenvolvimento de modelo de negócio em empresa startup}

brasileira de biotecnologia. 2018. 111 f. Dissertação (Mestrado) - Faculdade de Economia, Administração e Contabilidade, Universidade de São Paulo, 2018.

As empresas startup na área de biotecnologia podem adotar um portfólio de modelo de negócios diversificado com o intuito de maximizar a captação de valor do know how e das atividades associadas à pesquisa e desenvolvimento. O equilíbrio entre esses modelos de negócios é determinante para a geração de receita para subsidiar o longo prazo intrínseco ao desenvolvimento do negócio derivado de pesquisa e desenvolvimento em biotecnologia. Nesse cenário, é relevante a análise e seleção do método apropriado de construção de modelos de negócios para empresas startup no setor de biotecnologia. O presente estudo tem como objetivo desenvolver o modelo de negócios de uma startup de biotecnologia de diagnóstico molecular no mercado brasileiro. O método de pesquisa adotado foi a pesquisa-ação que derivou na seleção do método de construção de modelo de negócios descrito por Pedroso, 2018. A autora demonstra que a aplicação desse método em uma startup brasileira de biotecnologia gerou 4 ciclos interativos de planejamento, ação, avaliação e diagnóstico. Ainda, a autora aponta sugestões para a aplicação desse método em empresas brasileiras startup de biotecnologia.

Palavras chave: modelo de negócios, startup, biotecnologia. 


\begin{abstract}
KATZ, A. B. B. The development of a business model in a Brazilian biotechnology

startup. 2018. 111 f. Dissertação (Mestrado) - Faculdade de Economia, Administração e Contabilidade, Universidade de São Paulo, 2018.

Startups in the biotechnology area may adopt a diversified business model portfolio that seek to maximize the value of know-how and activities associated with research and development. The balance between these business models is decisive for the generation of revenue to subsidize the long term intrinsic to the development of the business derived from research and development in biotechnology. In this scenario, it is relevant to analyze and select the appropriate method to construct business models for startup companies in the biotechnology sector. The present study aims to develop the business model of a biotechnology startup on the molecular diagnostic sector in the Brazilian market. The research method adopted was the action research that resulted on the selection of the method of business model construction described by Pedroso, 2018. The author shows that the application of said method in a Brazilian biotech startup generated 4 interactive cycles of planning, action, evaluation and diagnostic. In addition, the author gives some suggestions for applying this method on Brazilian startups.
\end{abstract}

Keywords: business model, startup, biotechnology. 


\section{LISTA DE FIGURAS}

Figura 1. Estrutura do trabalho (Fonte: a autora).

Figura 2. Fluxograma da seleção de artigos como descrito em (I) (Fonte: adaptado de Esteves, Daumas, Oliveira, Andrade, \&

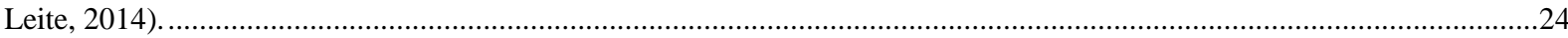

Figura 3. Fluxograma da seleção de artigos como descrito em (II) (Fonte: adaptado de Esteves et al., 2014).......................25

Figura 4. Fluxograma da seleção de artigos como descrito em (III) (Fonte: adaptado de Esteves et al., 2014). ......................26

Figura 5: Gráfico esquemático do fluxo realizado da Revisão Bibliográfica: revisão sistemática e revisão não estruturada

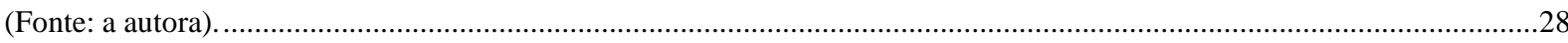

Figura 6: Etapas de busca e execução do modelo de negócios (Fonte: Blank e Dorf, 2012)............................................32

Figura 7: Ilustração das atividades chave em cada etapa do método do inovador (Fonte: Furr \& Dyer, 2014, p.30)..............35

Figura 8: Método de 24 estágios (A) reunidos em 6 etapas (B) para obtenção de um empreendimento do tipo IDE (Fonte:

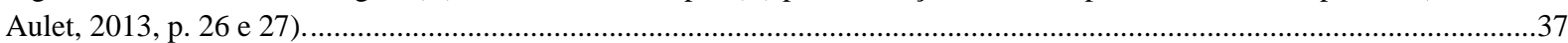

Figura 9: Método de 5 estágios para a procura do cálice sagrado da especificidade (Fonte: Aulet, 2013, p. 33).....................38

Figura 10: Fases do processo de construção de modelo de negócios descrito por Pedroso, 2018 (Fonte: Pedroso, 2018)........42

Figura 11: Ciclos do processo de construção de modelo de negócios descrito por Pedroso, 2018 (Fonte: Pedroso, 2018). .....43

Figura 12: As 21 etapas do processo de construção de modelo de negócios descrito por Pedroso, 2018 (Fonte: Pedroso, 2018).

Figura 13: Gráfico comparativo dos métodos de construção de modelo de negócios em startups. .........................................46

Figura 14: Ilustração das principais características do modelo de negócios do tipo Plataforma, Híbrido e Produto (Fonte:

Fisken \& Rutherford, 2002).

Figura 15: Blocos de construção do modelo de negócios e suas características em startups escandinavas de biotecnologia

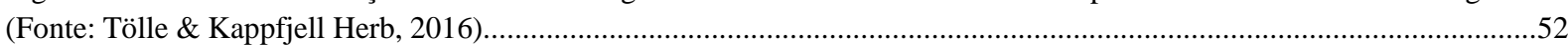

Figura 16: Tipologia de modelo de negócios em biotecnologia (Fonte: a autora)...........................................................54

Figura 17. Ilustração do procedimento metodológico (Fonte: a autora) .........................................................................56

Figura 18. Matriz de amarração metodológica planejada (Fonte: A autora) . ...................................................................57

Figura 19. Ilustração do ciclo da pesquisa-ação (Fonte: adaptado de Coghlan \& Brannick, 2014).....................................61

Figura 20. Ilustração dos ciclos interativos da pesquisa-ação (Fonte: adaptado de (Coghlan \& Brannick, 2014)....................63

Figura 21. Ciclos 1, 2, 3 e 4 da pesquisa-ação do presente estudo correspondentes as fases definidas no método de construção

de modelo de negócios descrito por Pedroso, 2018 (Fonte: A autora) . .................................................................................66

Figura 22. Ciclos planejados da pesquisa-ação para a execução das etapas do procedimento de geração de modelo de

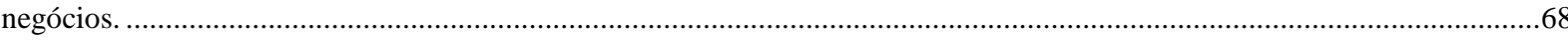

Figura 23. Ciclos realizados da pesquisa-ação para o cumprimento das etapas do procedimento de geração de modelo de

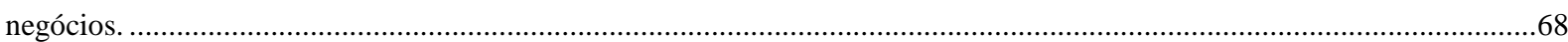

Figura 24. O processo de identificação de oportunidades engloba os parâmetros de megatendências, ecossistema (cadeia de

valor), modelo de negócios e empreendedor (Fonte: Pedroso, 2018) ..........................................................................69

Figura 25. Quadro ilustrativo que resume os resultados da etapa 1 do ciclo 1 (Fonte: adaptado de Pedroso, 2018)...............72

Figura 26. Tamanho de mercado alvo da startup Sampa Tech (Fonte: adaptado de Pedroso, 2018)......................................75

Figura 27. Quadro ilustrativo que resume os resultados da etapa 2 do ciclo 1. (Fonte: adaptado de Pedroso, 2018 ..............76

Figura 28. Quadro ilustrativo que resume os resultados da etapa 3 do ciclo 1 (Fonte: adaptado de Pedroso, 2018...............78

Figura 29. Quadro ilustrativo que resume os resultados da etapa 4 do ciclo 1. (Fonte: adaptado de Pedroso, 2018)..............81

Figura 30. Quadro ilustrativo que resume os resultados da etapa 5 do ciclo 1. (Fonte: adaptado de Pedroso, 2018).............82

Figura 31. Tipologia e Submodelo de Modelo de Negócios. (Fonte: adaptado de Pedroso, 2018)....................................82

Figura 32. Quadro ilustrativo que resume os resultados da etapa 6 do ciclo 2 (Fonte: adaptado de Pedroso, 2018)................83

Figura 33. Matriz de avaliação de valor da Sampa Tech (Fonte: A autora). ...................................................................85

Figura 34. Canvas da proposta de valor da Sampa Tech (Fonte: adaptado de Osterwalder, Pigneur, Bernarda, \& Smith, 2014).

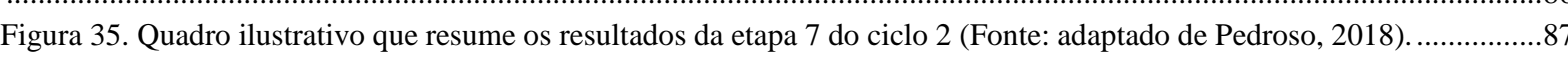

Figura 36. Tipologia e Submodelo de Modelo de Negócios associado ao posicionamento competitivo (Fonte: adaptado de

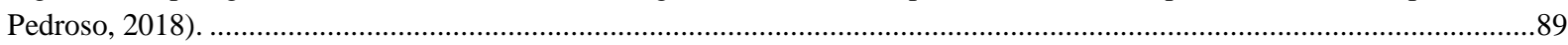

Figura 37. Quadro ilustrativo que resume os resultados da etapa 8 do ciclo 2 (Fonte: adaptado de Pedroso, 2018) ...............89

Figura 38. Tipologia e Submodelo de Geração de Receita (Fonte: adaptado de Pedroso, 2018). ......................................90

Figura 39. Quadro ilustrativo que resume os resultados da etapa 9 do ciclo 2 (Fonte: adaptado de Pedroso, 2018)...............90

Figura 40. Canvas da validação da solução (Fonte: adaptado de Pedroso, 2018)..............................................................92

Figura 41. Quadro ilustrativo que resume os resultados da etapa 10 do ciclo 2 (Fonte: adaptado de Pedroso, 2018) ..............93

Figura 42. Esquematização da estrutura de cálculo do EVA (Fonte: Pedroso, 2018). ....................................................94 
Figura 43. Tipologia do Modelo Econômico (Fonte: adaptado de Pedroso, 2018).

Figura 44. Quadro ilustrativo que resume os resultados das etapas 11 e 12 do ciclo 3 (Fonte: adaptado de Pedroso, 2018)....95

Figura 45. Canvas da segunda proposta de valor da Sampa Tech (Fonte: adaptado de Osterwalder et al., 2014). .................97

Figura 46. Quadro ilustrativo que resume os resultados da etapa 9 do ciclo 4 (Fonte: adaptado de Pedroso, 2018). ..............98

Figura 47. Quadro ilustrativo que resume os resultados das etapa 11 e 12 do ciclo 4 (Fonte: adaptado de Pedroso, 2018). ....99

Figura 48. Tipologia do Modelo de Operações (Fonte: adaptado de Pedroso, 2018). ..................................................... 101

Figura 49. Tipologia do Modelo de Relacionamento com clientes (Fonte: adaptado de Pedroso, 2018). ........................... 102

Figura 50. Fórmula de cálculo de LTV (Fonte: adaptado de Pedroso, 2018 ....................................................................... 103

Figura 51. Fórmula de cálculo do COCA (Fonte: adaptado de Pedroso, 2018) ................................................................ 103

Figura 52. Quadro ilustrativo que resume os resultados da etapa 14 do ciclo 4 (Fonte: adaptado de Pedroso, 2018). .......... 104

Figura 53. Tipologia do Modelo de Inovação (Fonte: adaptado de Pedroso, 2018)...................................................... 105

Figura 54. Representação do modelo de gestão do tipo descoberta (Fonte: Pedroso, 2018) ............................................. 106

Figura 55. Tipologia do Modelo de Gestão (Fonte: adaptado de Pedroso, 2018). ........................................................... 106

Figura 56. Quadro ilustrativo que resume os resultados da etapa 16 do ciclo 4 (Fonte: adaptado de Pedroso, 2018). ..........107

Figura 57. Quadro ilustrativo que resume os resultados das etapas 18 e 19 do ciclo 4 (Fonte: adaptado de Pedroso, 2018). 107

Figura 58. Esquematização do modelo de negócios da Sampa Tech (Fonte: adaptado de Pedroso, 2017)........................... 109

Figura 59: Ciclos realizados de pesquisa ação (Fonte: a autora). ............................................................................. 118

Figura 60: Resultados resumidos do trabalho (Fonte: a autora).............................................................................. 121

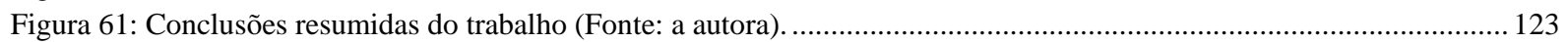




\section{LISTA DE SIGLAS}

BIOTECH

CAGR

CIETEC

EUA

FAPESP

FINEP

IPT

P\&D

USP
Empresa do setor de Biotecnologia

Taxa de composta de crescimento anual

Centro de Inovação, Empreendedorismo e Tecnologia

Estados Unidos da América

Fundação de Amparo à Pesquisa do Estado de São Paulo

Financiadora de Estudos e Projetos

Instituto de Pesquisa Tecnológica do estado de São Paulo

Pesquisa e Desenvolvimento

Universidade de São Paulo 



\section{SUMÁRIO}

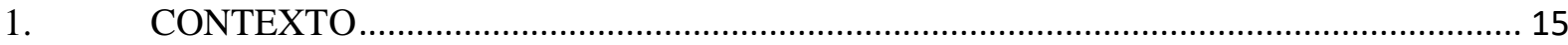

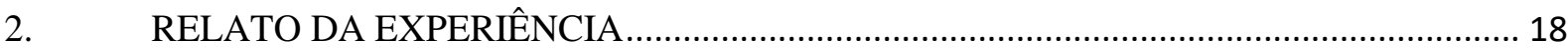

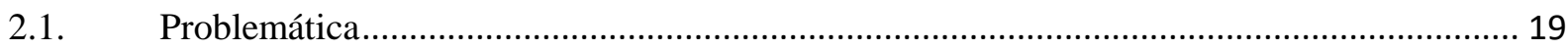

2.2. Questão de pesquisa .................................................................................................. 20

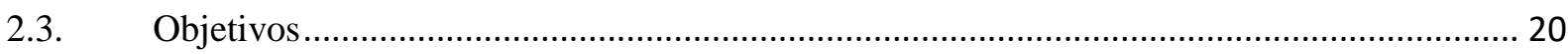

2.3.1. Objetivo principal............................................................................................. 20

2.3.2. Objetivos secundários ……………………………………………………….... 20

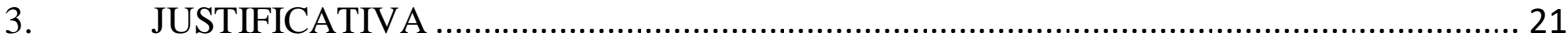

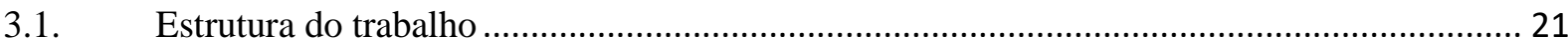

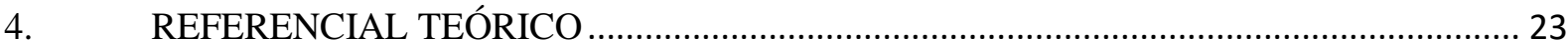

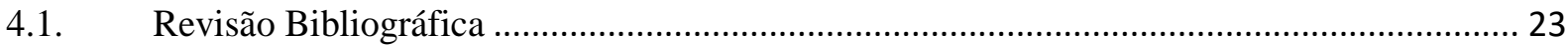

4.1.1 Revisão sistemática ........................................................................................... 23

4.1.2 Revisão não estruturada ……………………………………………………………..... 27

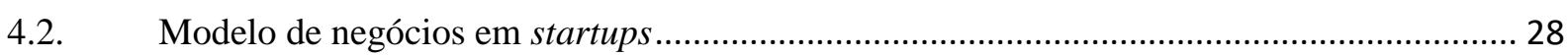

4.3. Construção de modelo de negócios em startup ………………………………………….... 30

4.4. Construção de modelo de negócios em startup fundamentada em alta tecnologia ................ 35

4.5. Construção de modelo de negócios em startups em biotecnologia ....................................... 47

5. MÉTODO DE PESQUISA ……………………………………………………. 55

5.1. Matriz de Amarração Metodológica ............................................................................... 56

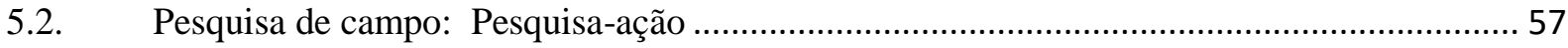

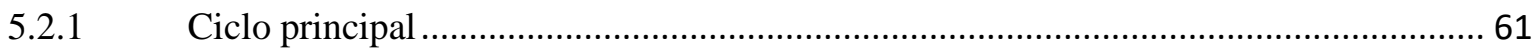

5.2.2 Ciclo de reflexão .............................................................................................. 63

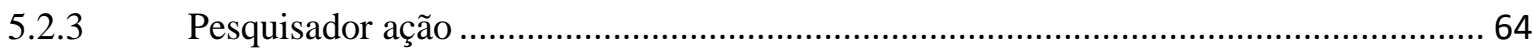

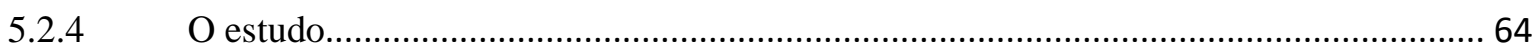

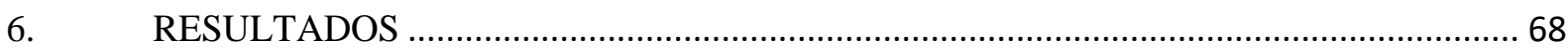

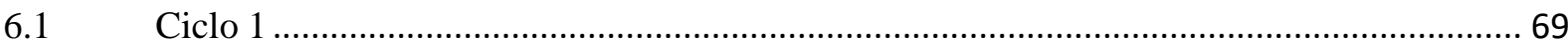

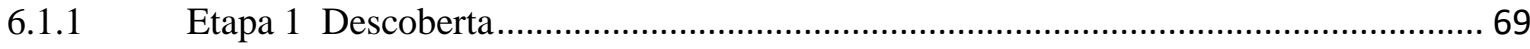

6.1.2 Etapa 2 Tamanho de mercado …………………………………………………. 72

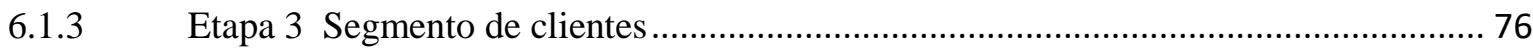

6.1.4 Etapa 4 Problema a ser resolvido ……………………………………………….... 78

6.1.5 Etapa 5 Validação do problema............................................................................... 81 


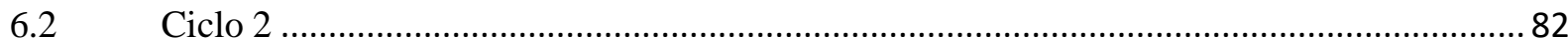

6.2.1 Etapa 6 Tipo do Modelo de Negócios ........................................................................ 82

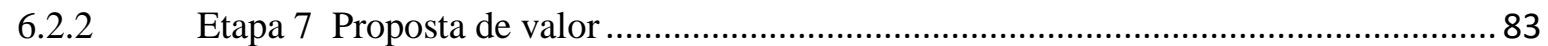

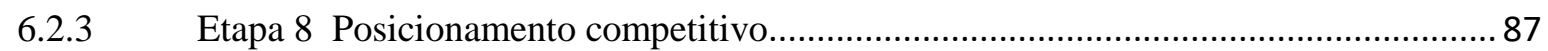

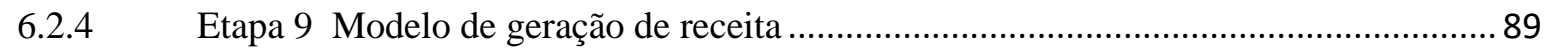

6.2.5 Etapa 10 Validação da solução ………………………............................................. 90

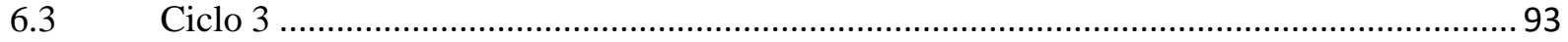

6.3.1 Etapas 11 e 12 Modelo econômico: Estrutura de custos e Fórmula de lucro .................. 93

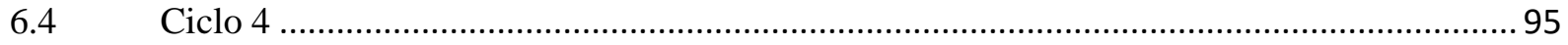

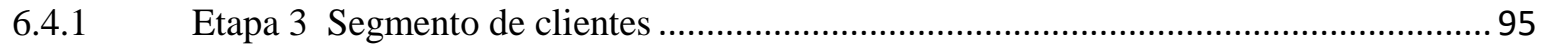

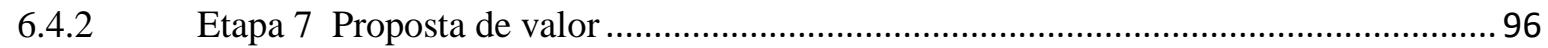

6.4.3 Etapa 9 Modelo de Geração de Receita .......................................................................... 97

6.4.4 Etapa 11 e 12 Modelo Econômico: Estrutura de Custos e fórmula de lucro .................. 98

6.4.5 Etapa 13 Modelo de Operações ............................................................................ 100

6.4.6 Etapa 14 Modelo de Relacionamento com clientes ................................................... 101

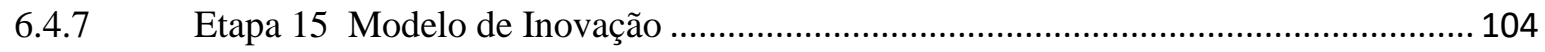

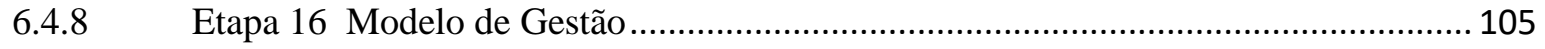

6.4.9 Etapa 17 Modelo de Negócios (Inicial) …............................................................... 107

6.4.10 Etapas 18 e 19 Estrutura de Custos (calculada) e Geração de Valor ............................. 107

6.4.11 Etapa 20 Validação do Modelo de negócios................................................................. 108

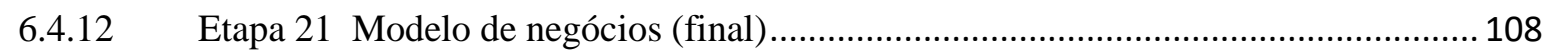

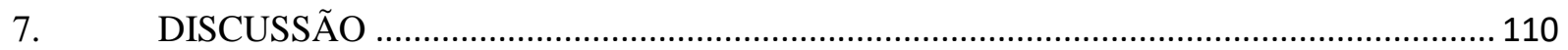

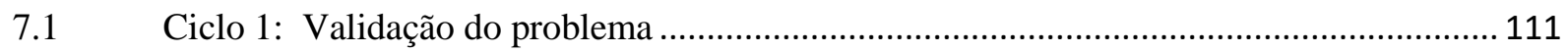

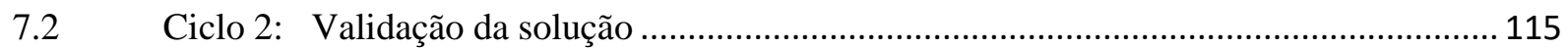

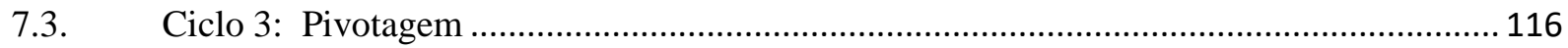

7.3. Ciclo 3: Validação do modelo de negócios ........................................................................... 117

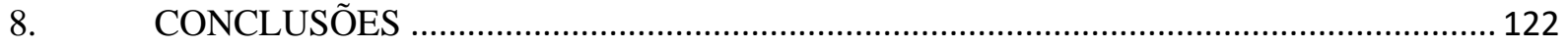

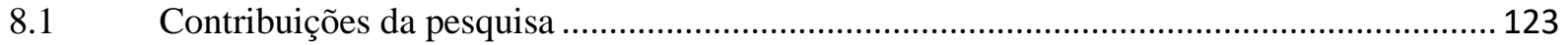

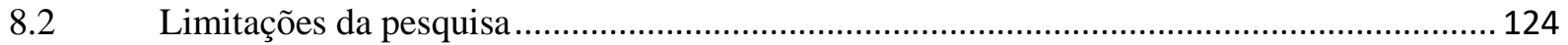

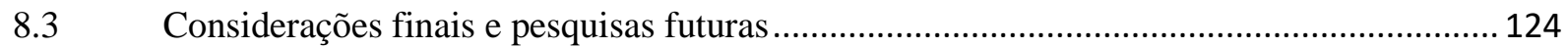

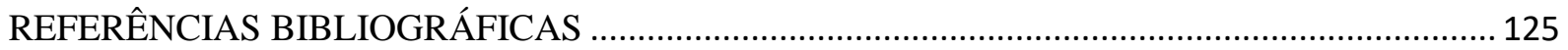




\section{CONTEXTO}

O modelo de negócios descreve o racional de como uma organização cria, entrega e captura valor. Interessante notar que não existe um único modelo de negócios cabível a uma empresa, e sim, muitas oportunidades e opções que devemos desvendar para a melhor escolha do modelo (Osterwalder \& Pigneur, 2010).

Iniciar e sustentar uma startup ${ }^{l}$ fundamentada em P\&D, particularmente no setor de biotecnologia, requer um modelo de negócios que aperfeiçoe estratégias de financiamento, mercado e operacional (Tsai \& Erickson, 2006). A literatura sugere que diferenciar o modelo de negócios na indústria de tecnologia da saúde é de grande relevância (Lehoux, Daudelin, Williams-Jones, Denis \& Longo, 2014).

A estratégia de financiamento é frequentemente o maior desafio da startup em biotecnologia em face do longo desenvolvimento do produto, e consequente retardamento do início da geração de receita, que é intrínseco dessa indústria. O financiamento é necessário para gerar ganhos para operações, e assim direcionar o desenvolvimento do produto e estratégias de negócio.

Observa-se que algumas startups em biotecnologia adotam um portfólio diversificado de modelos de negócios visando maximizar a captação de valor do seu know how e das atividades associadas à $\mathrm{P} \& \mathrm{D}$. $\mathrm{O}$ equilíbrio entre os modelos de negócio é determinante para a geração de receita a curto e médio prazo, para subsidiar o longo prazo intrínseco ao desenvolvimento do negócio derivado de P\&D em biotecnologia (Sabatier, Mangematin \& Rousselle, 2010).

O diagnóstico molecular é um segmento da biotecnologia, e resultado de avanços do conhecimento na biomedicina que permitem associar genética, expressão gênica ${ }^{2}$ e diagnóstico (Kurtzman, 2005). Atualmente, o principal mercado de diagnósticos moleculares está associado à saúde humana que engloba diagnósticos para doenças infecciosas, doenças crônicas, doenças sexualmente transmissíveis, oncologia e testes genéticos (Miller, 2014).

\footnotetext{
${ }^{1}$ A definição adotada nesse trabalho é que uma empresa startup é uma organização temporária na busca de um modelo de negócios escalável, reprodutível e rentável (Blank \& Dorf, 2012).

${ }^{2}$ Expressão gênica pode ser definido como a expressão de um gene, ou seja, como o ADN silencioso e bem guardado é expresso para fazer ARN, e como o ARN mensageiro é traduzido de codificação de ácido nucleico para codificação de proteínas para formar uma proteína (Hoopes, 2008).

formar uma proteína (Hoopes, 2008).
} 
Tais diagnósticos visam permitir o tratamento de paciente de maneira personalizada e mais eficiente.

Atualmente, o mercado global de diagnósticos mostra um crescimento maior que o observado na indústria farmacêutica correspondendo a CAGR (2014/2020) estimado em 9,8\% (Ravishankar, 2014; Shields \& Dhabale, 2014). Em 2012, esse mercado foi avaliado em U\$50 bilhões, havendo a estimativa de alcançar U\$70 bilhões em 2017 (Miller, 2014; Kurtzman, 2005).

É descrito na literatura que esse crescimento ocorreu em consequência de: (i) tentativa de mudança de modelo das empresas farmacêuticas - de blockbuster para medicina personalizada, (ii) alteração para modelo de diagnóstico point of care $^{3}$, (iii) necessidade de diagnósticos mais rápidos, (iv) aumento de demanda nos países emergentes, e (v) envelhecimento da população (Kurtzman, 2005).

Vale ressaltar que embora as despesas diretas com diagnósticos representem menos que $5 \%$ das despesas com saúde, o correto diagnóstico e subsequente tratamento da doença afeta os outros $95 \%$ correspondendo a U\$ 1.7 trilhões. Esse cenário reflete na grande relevância desse setor para o sistema de saúde em face ao seu potencial de economia em despesas médicas (Kurtzman, 2005).

Em face ao mercado em expansão pode-se inferir que a startup em diagnósticos moleculares é de grande relevância para o segmento. Ainda, empreendedores na área de biotecnologia são atraídos para o segmento de diagnósticos molecular visto seu potencial para a obtenção de produto comercializado em período mais curto ( 5 a 6 anos nos EUA), em face da natureza da tecnologia e ausência de regulamentação sanitária restritiva (ex. ensaios clínicos) quando comparado com o desenvolvimento de farmacêuticos, que corresponde a período em torno de 2 vezes mais longo (8-12 anos nos EUA). Corroborando com o mercado em expansão pode-se inferir que uma startup em diagnósticos moleculares é de grande relevância para o setor de biotecnologia.

\footnotetext{
${ }^{3}$ Point of care pode ser definido como testes projetados para serem usados em ou perto de do local onde o paciente está localizado, que não requer espaço dedicado permanente e que são realizados fora das instalações físicas dos laboratórios clínicos (em https://wwwn.cdc.gov/cliac/pdf/addenda/cliac0207/Addendu mf.pdf).
} 
Em geral, as estratégias de negócio em diagnóstico são delineadas para incluir o direcionamento de portfólio em área específica, licenciamento de plataformas de tecnologia e parcerias com institutos de pesquisa (Ravishankar, 2014).

Interessante notar que um levantamento realizado pelo MIT em 2017, mostrou que entre as empresas que melhor combinam tecnologia inovadora com modelo de negócios eficaz, 1/5 eram empresas de biomedicina (Massachusetts Institute of Technology [MIT] 2017) ${ }^{4}$. Esse fato corrobora a relevância do modelo de negócios em empreendimento orientados pela inovação, particularmente no setor de biotecnologia.

\footnotetext{
${ }^{4}$ Vale ressaltar que essa lista tem como objetivo enumerar empresas notáveis que foram eficientes em refletir resultados positivos para o negócio em si quanto da exploração dos avanços da inovação, e não em número de patentes e despesas em pesquisa e desenvolvimento. Ou seja, empresas que conseguiram converter a tecnologia inovadora em ganhos reais por meio do alinhamento da inovação com seu modelo de negócios.
} 


\section{RELATO DA EXPERIÊNCIA}

A Sampa Tech é o codinome de uma startup brasileira atuante no setor de biotecnologia, mais especificamente no segmento de diagnóstico molecular. Essa startup possui suas atividades focadas em $\mathrm{P} \& \mathrm{D}$ visando o desenvolvimento de diagnósticos moleculares inovadores em plataforma tecnológica própria de point of care (POC).

A startup Sampa Tech foi fundada em 2011 pela autora desse trabalho e pelo seu sócio (co-fundador). Ambos os co-fundadores da Sampa Tech possuem formação acadêmica em ciências da vida e experiência corporativa. A pesquisadora desse trabalho é mestre e Ph.D em biologia molecular pela Universidade Federal do Rio de Janeiro, foi cientista visitante na Harvard Medical School e gerente de patentes, desenvolvimento de negócios e inovação na indústria farmacêutica. Atualmente, é gestora de novos negócios na Sampa Tech.

Em 2011, a empresa associou-se a incubadora CIETEC localizada na Cidade Universitária (USP) onde instalou seu escritório administrativo por 2 anos. Recentemente, a Sampa Tech instalou sua estrutura própria de laboratório na mesma incubadora.

No período entre 2010 e $3^{\circ}$ Trimestre de 2013, a Sampa Tech seguiu um modelo virtual de P\&D. Por meio desse modelo, a startup projetou e desenvolveu uma plataforma tecnológica inovadora de diagnóstico molecular e contratou prestadores de serviços para testá-la (ex. IPT). A partir do $4^{\circ}$ Trimestre de 2013, a Sampa Tech começou a seguir um modelo misto de $\mathrm{P} \& \mathrm{D}$, e assim, realizar a maior parte de desenvolvimento em seu laboratório e contratar prestadores de serviços somente para realização de testes complementares.

A Sampa Tech é proprietária da Propriedade Intelectual referente à plataforma inovadora de diagnóstico molecular que desenvolveu. A proteção inclui o componente principal desta plataforma, denominado de biossensor.

Com relação ao financiamento de suas operações, que é um foco primordial para startups em biotecnologia, a Sampa Tech utiliza recursos próprios e oriundos de linhas de financiamento disponibilizadas pelo governo brasileiro em fomento. 
O longo período entre o início do desenvolvimento e o lançamento do produto é uma realidade de empresas em biotecnologia que também ocorre na Sampa Tech. A empresa sempre mostrou foco na tentativa de geração de receita para sustentar suas atividades, e ainda com a forma de alcançar sua escalabilidade.

Durante o desenvolvimento do produto a empresa validou e construiu uma plataforma tecnológica para POC genético.

Atualmente, a Sampa Tech está na fase de finalização de três protótipos de diagnóstico molecular point of care baseado em sua plataforma tecnológica inovadora. A previsão é que os mesmos alcancem o mercado em 2021.

\subsection{Problemática}

A busca da Sampa Tech por um modelo de construção de modelo de negócios representa uma realidade vivenciada por startups que se fundamentam em P\&D de desenvolvimento longo, mais particularmente no setor de biotecnologia. Ainda, é fato que muitas empresas startups no setor de biotecnologia não atingem a escalabilidade, o que ameaça seu crescimento e também o lançamento de seu produto inovador no mercado.

É descrito na literatura que muitas startups na área da saúde permanecem dependentes de investidores. Por outro lado, investidores tendem a buscar startups fundamentadas em tecnologia que forneçam retorno sobre o investimento em curto prazo. Nesse cenário, muitas dessas empresas não passam do limiar da sustentabilidade (Lehoux, Daudelin, Williams-Jones, Denis \& Longo, 2014).

A proposição de um um método de construção de modelo de negócios apropriado para o setor de biotecnologia poderia auxiliar no sucesso dessas empresas, particularmente no cenário brasileiro.

Portanto, torna-se relevante a seleção de uma metodologia para a construção de modelos de negócios visando a geração de uma empresa startup fundamentada em inovação. Ainda, torna-se relevante a seleção de uma metodologia para o desenvolvimento de um modelo de negócios de uma startup de biotecnologia. É particularmente relevante a 
investigação dos métodos de construção de modelo de negócios em empresas startup brasileira em biotecnologia.

\subsection{Questão de pesquisa}

Face ao exposto acima, o presente trabalho visa desenvolver a pesquisa para elucidar a seguinte questão de pesquisa:

Como desenvolver o modelo de negócios de uma startup de biotecnologia de diagnóstico molecular no mercado brasileiro?

\subsection{Objetivos}

\subsubsection{Objetivo principal}

Desenvolver o modelo de negócios de uma startup de biotecnologia de diagnóstico molecular no mercado brasileiro.

\subsubsection{Objetivos secundários}

1. Identificação de métodos para a construção de modelos de negócios em empresa startup de biotecnologia.

2. Seleção de um método para a construção de modelo de negócios para a intervenção em uma empresa startup de biotecnologia de diagnóstico molecular no mercado brasileiro.

3. Aplicação de um método para a construção de modelo de negócios para a intervenção em uma empresa startup de biotecnologia de diagnóstico molecular no mercado brasileiro. 


\section{JUSTIFICATIVA}

Justifica-se a presente pesquisa em função da contribuição que pode ser dada por este estudo ao entendimento sobre a construção de modelo de negócios em biotecnologia. Para tal, é fundamental entender como são definidos os métodos para o desenvolvimento de modelos de negócios aplicados em startups fundamentadas em inovação, particularmente em biotecnologia.

Além disso, justifica-se a pesquisa pela relevância da definição dos métodos de construção de modelo de negócios em empresas startup brasileira de biotecnologia.

Este estudo pretende contribuir, pretensiosamente, para compreender e analisar as fases consideradas no processo de construção de modelo de negócios em uma empresa startup brasileira em biotecnologia.

Acredita-se, em função de serem ainda incipientes os estudos, com a abordagem aqui apresentada, que a atual pesquisa poderá contribuir tanto academicamente com o tema quanto na prática. Poderá contribuir academicamente, com uma validação de um método de construção de modelo de negócios em empresas startup brasileira de biotecnologia, e, na prática, o resultado da pesquisa poderá servir como guia prático para a construção de modelo de negócios em empresas startup brasileira em biotecnologia.

\subsection{Estrutura do trabalho}

O presente trabalho está organizado no resumo, e mais nove capítulos que podem ser visualizados na Figura 1. No primeiro capítulo, apresentam-se a introdução. No segundo capítulo, o relato da experiência que inclui a problemática, a questão de pesquisa e os objetivos. No terceiro capítulo, é descrita a justificativa para a realização deste trabalho, e a estrutura do trabalho. No quarto capítulo, realiza-se a revisão da literatura que é apresentada no referencial teórico. Em seguida, no capítulo 5, é apresentada a metodologia utilizada para a realização da pesquisa. No capítulo 6 são apresentados os resultados da pesquisa de campo. No capítulo 7 é realizada feita a confrontação da prática com a teoria. A seguir, no capítulo 7 , são discutidas as conclusões. Esse capítulo apresenta as considerações finais da pesquisa, 
como contribuições e limitações do estudo, bem como sugestões para estudos futuros. O trabalho se conclui com a lista das referências bibliográficas e dos anexos.

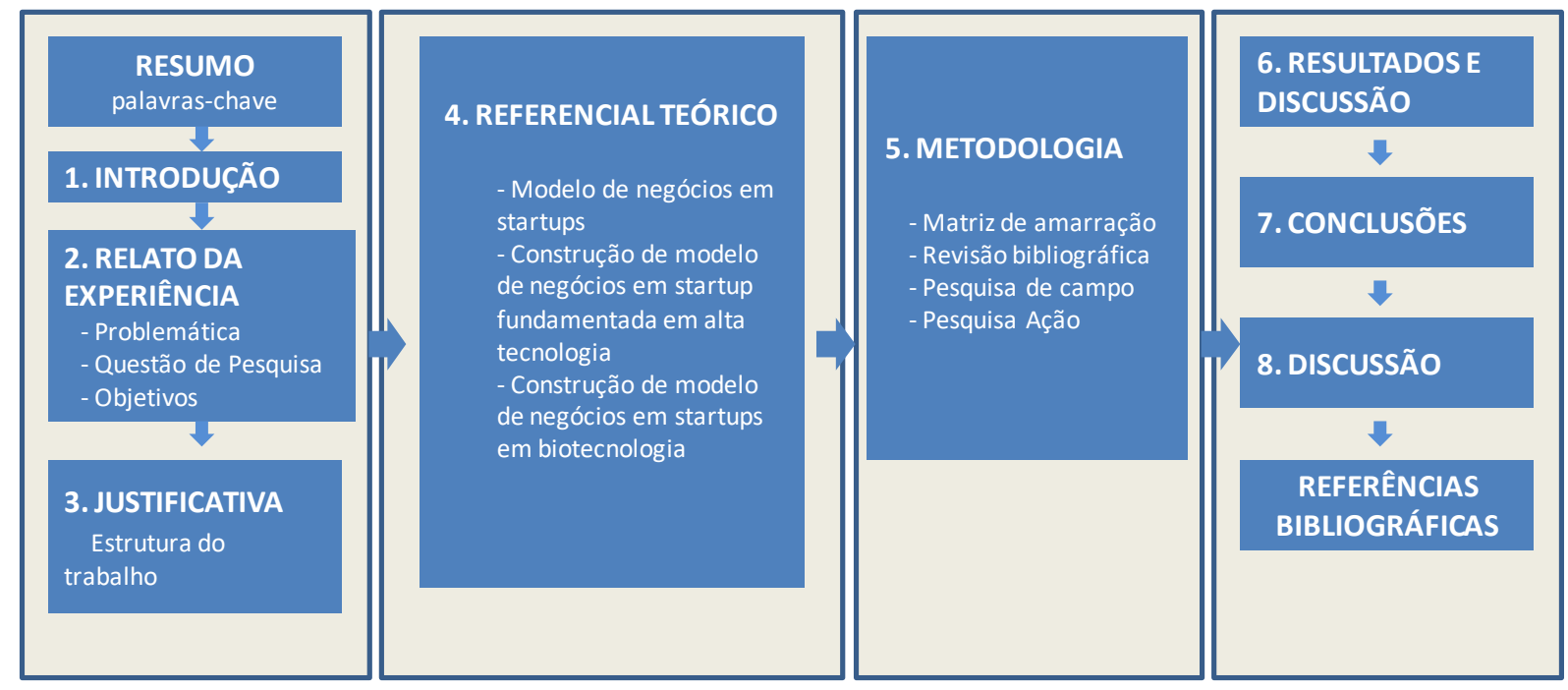

Figura 1. Estrutura do trabalho (Fonte: a autora). 


\section{REFERENCIAL TEÓRICO}

\subsection{Revisão Bibliográfica}

A revisão bibliográfica nesse estudo foi realizada por meio de pesquisa bibliográfica utilizando fontes secundárias de dados. Esse tipo de pesquisa é fundamental para realizar pesquisas científicas de qualquer natureza, pois busca conhecer, analisar e discutir um assunto ou problema a partir de um referencial teórico (Martins \& Theóphilo, 2009).

O método de análise de dados que melhor se adéqua para a análise das referidas informações é o método comparativo. O método comparativo pode ser definido como um método para definir a relação empírica entre as variáveis por meio do confronto entre elementos levando em consideração seus atributos (Lijphart, 1971).

Mais especificamente, a revisão bibliográfica foi realizada por meio de: revisão sistemática e revisão não estruturada.

\subsubsection{Revisão sistemática}

Foi realizada a revisão sistemática por meio da consulta da base de dados Google Acadêmico e a posterior seleção dos artigos científicos, teses e livros de maior relevância publicados até a data de 17/06/2017, com relação à todos as matérias: modelo de negócios, startup, empreendimentos orientados a inovação e biotecnologia para entender os métodos de construção de modelo de negócios em empresas orientadas a inovação, particularmente biotecnologia. Foram utilizadas diversas combinações de palavras-chave de forma a aperfeiçoar o resultado da revisão bibliográfica, da forma descrita a seguir.

I. Foi utilizada como descritor a frase exata "business model" juntamente com o operador booleano AND com no mínimo uma das palavras "innovation driven enterprise" OR IDE, AND com todas as palavras biotechnology. Em uma pesquisa bibliográfica em paralelo foi utilizada como descritor a frase exata "business model" juntamente com o operador booleano AND com todas as palavras "innovation driven enterprise". Ambas as pesquisas consideraram as 
condições para encontrar em qualquer lugar das referências, a qualquer momento, qualquer idioma, e incluindo patentes e citações. Foram encontradas 541 e 37 referências bibliográficas, respectivamente. Tais referências foram analisadas no conteúdo de seu título e resumo, com o objetivo de excluir as referências irrelevantes tais como as relacionadas a casos específicos de países, ecossistemas, equipe e outros. Foi selecionado o total de 11 referências considerando as duas análises. O fluxograma dessa seleção de artigos é ilustrado na Figura 2.

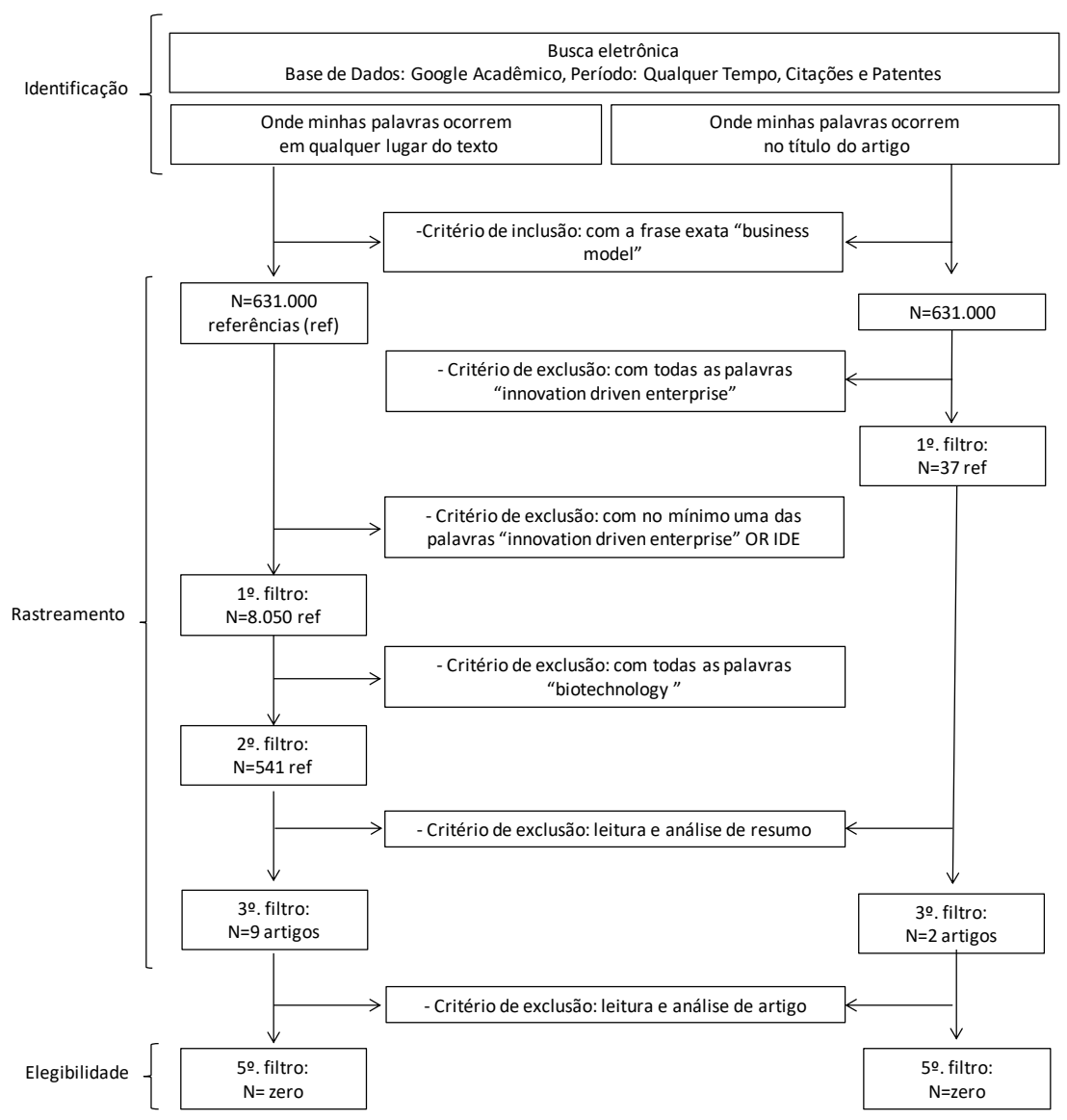

Figura 2. Fluxograma da seleção de artigos como descrito em (I) (Fonte: adaptado de Esteves, Daumas, Oliveira, Andrade, \& Leite, 2014).

II. Foi utilizada como descritor a frase exata "business model" juntamente com o operador booleano AND com no mínimo uma das palavras biotechnology ou biotech AND com todas as palavras startup e technology push em qualquer lugar da referência. Ainda, em segunda análise, foi utilizada como descritor a frase exata "business model" juntamente com o operador booleano AND com no mínimo uma 
das palavras biotechnology ou biotech no título de referência. Ambas as pesquisas consideraram as condições para encontrar as referências a qualquer momento, qualquer idioma, e incluindo patentes e citações. Foram encontradas 588 e 43 referências bibliográficas, respectivamente. Tais referências foram analisadas no conteúdo de seu título e resumo, com o objetivo de excluir as referências irrelevantes tais como as relacionadas a casos específicos de países, ecossistemas, equipe e outros. As referências incluídas contemplam modelo de negócios, biotecnologia (ou biotech) e startup e orientação à tecnologia no contexto de modelo de negócios ou fatores críticos para o sucesso da empresa. Foi selecionado o total de 36 referências considerando as duas análises. O fluxograma dessa seleção de artigos é ilustrado na Figura 3.

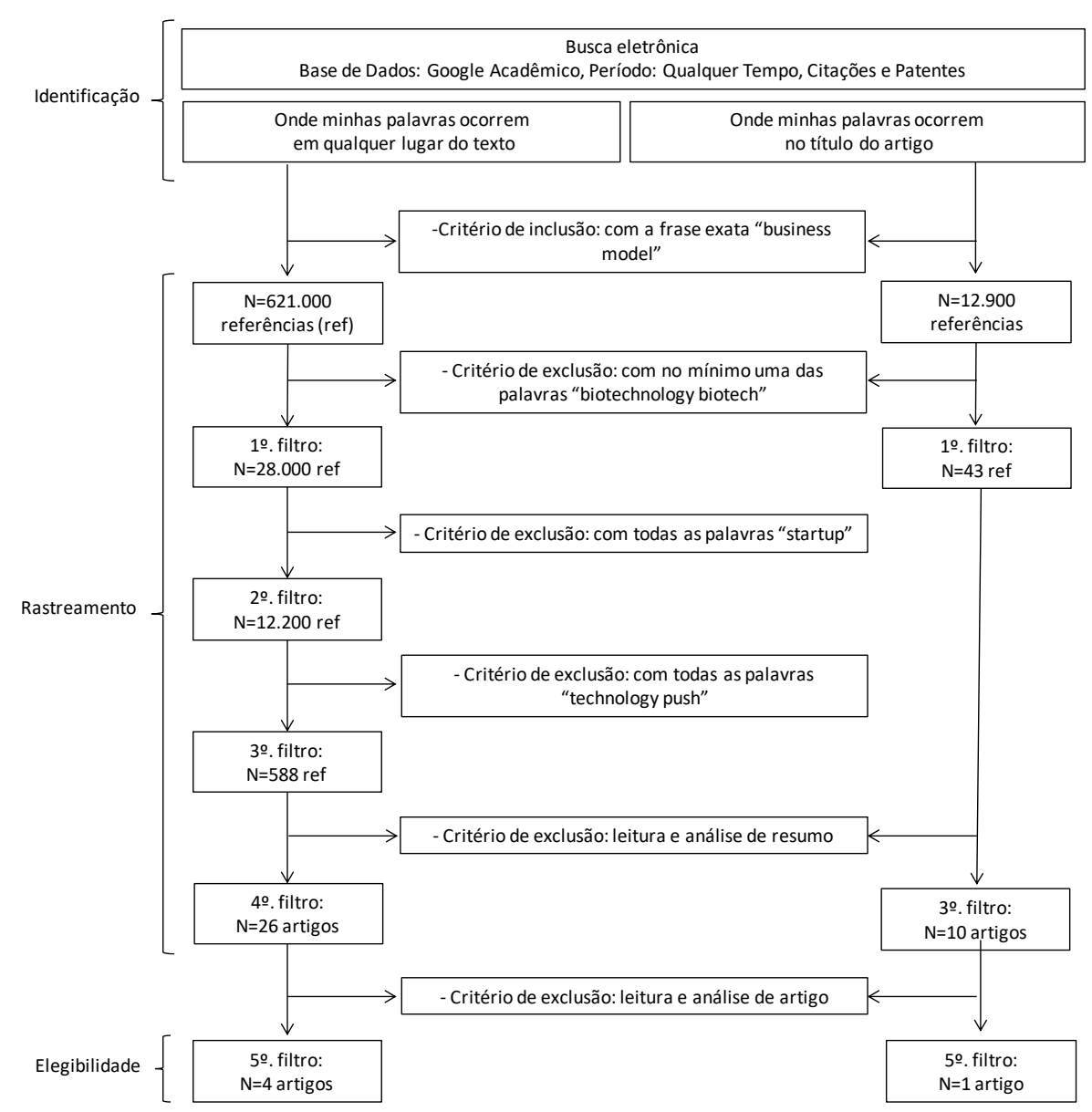

Figura 3. Fluxograma da seleção de artigos como descrito em (II) (Fonte: adaptado de Esteves et al., 2014). 
III. Foi utilizada como descritor a frase exata "lean startup" juntamente com o operador booleano AND com todas as palavras startup AND com no mínimo uma das palavras biotechnology ou biotech em qualquer lugar da referência. Ainda, em segunda análise, foi utilizada como descritor a frase exata a frase exata "lean startup" juntamente com o operador booleano AND com todas as palavras startup AND com no mínimo uma das palavras biotechnology ou biotech no título de referência. Ambas as pesquisas consideraram as condições para encontrar as referências a qualquer momento, qualquer idioma, e incluindo patentes e citações. Foram encontradas 400 e 291 referências bibliográficas, respectivamente. Tais referências foram analisadas no conteúdo de seu título e resumo, com o objetivo de excluir as referências irrelevantes tais como as relacionadas a casos específicos de países, ecossistemas, equipe e outros. Foi selecionado o total de 51 referências considerando as duas análises. O resultado dessa seleção de artigos é ilustrado na Figura 4.

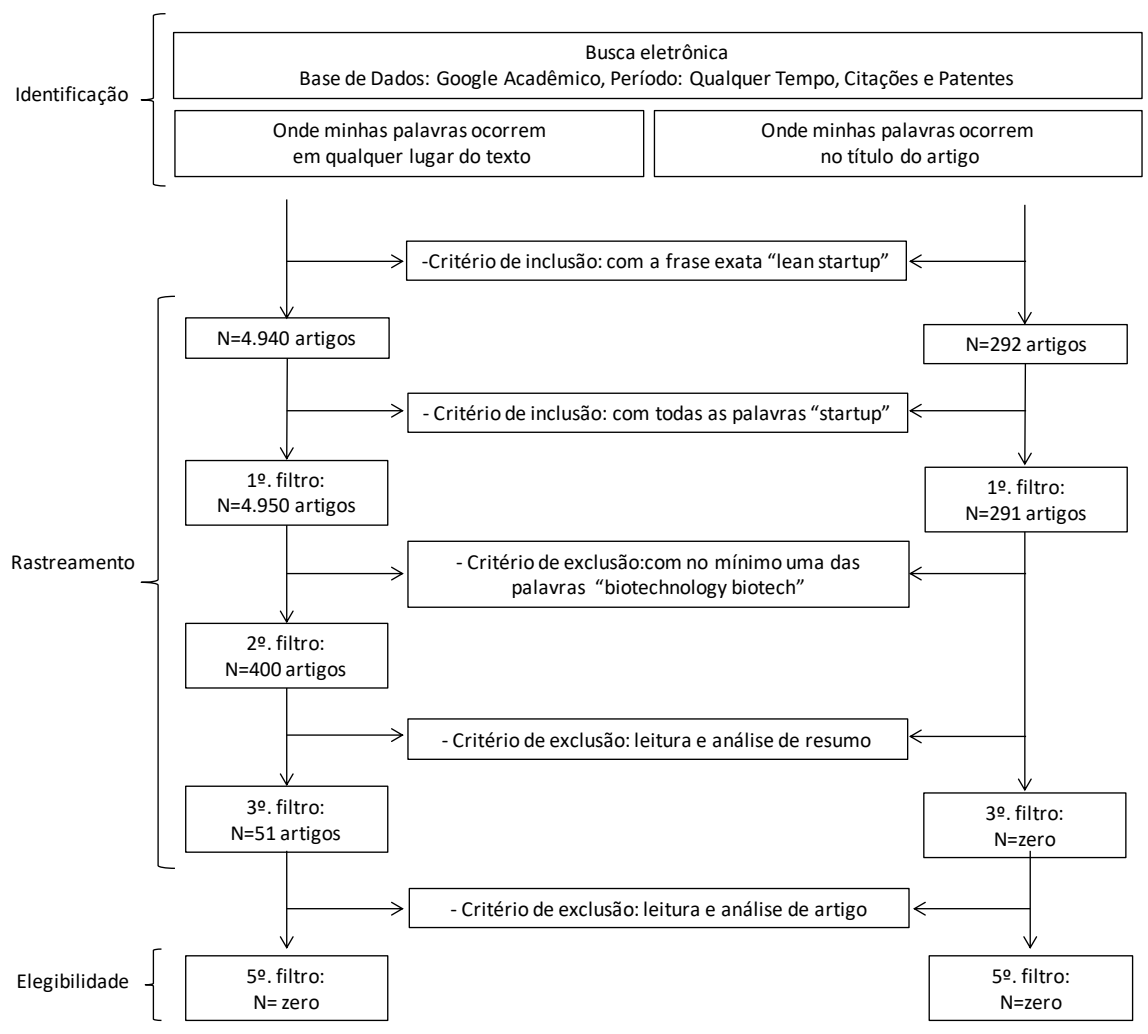

Figura 4. Fluxograma da seleção de artigos como descrito em (III) (Fonte: adaptado de Esteves et al., 2014). 
Na revisão estruturada não foi encontrada referências relevantes com relação a um método específico para construção de modelo de negócios em empresa startup de biotecnologia. Entretanto, foram encontradas referências bibliográficas quanto aos componentes de modelo de negócios em startups de biotecnologia. Mais especificamente, as referências consideradas pela autora como relevantes são: Tölle \& Kappfjell Herbst, 2016, Sabatier, Mangematin \& Rousselle, 2010, Tsai \& Erickson, 2006, Fisken \& Rutherford, 2002, e Nosella, Petroni \& Verbano, 2006.

\subsubsection{Revisão não estruturada}

Interessante notar que não foi encontrada referência que versa sobre método para construção de modelo de negócios especificamente em empresa startup de biotecnologia. Dessa forma, a autora realizou uma pesquisa de forma não estruturada com o objetivo de selecionar referências sobre métodos de construção de modelo de negócios em empresas startup.

Nessa revisão, a autora selecionou referências relativas ao método de construção de modelo de negócios tanto em empresas startups de qualquer setor, não necessariamente inovadoras, como também em empresas startups direcionadas pela inovação. A autora selecionou como relevantes as referências: Osterwalder \& Pigneur, 2010, Blank \& Dorf, 2012, Aulet, 2013, Gassmann et al., 2014, Furr e Dyer, 2014 e Pedroso, 2018.

De forma resumida, a revisão bibliográfica realizada nesse estudo consistiu na revisão sistemática e revisão não estruturada tal como ilustrado na Figura 5. A revisão sistemática primeiramente focou na busca por métodos de construção de modelo de negócios em biotecnologia. Visto que não foi encontrada referência relevante nessa análise, a autora realizou uma revisão não estruturada pela qual encontrou 6 modelos de construção de modelo de negócios aplicados em startups e que foram considerados no presente estudo, particularmente na pesquisa-ação. Ao mesmo tempo, a revisão sistemática mostrou publicações relevantes com relação aos componentes de modelo de negócios em empresas de biotecnologia. Tais referências são consideradas e analisadas como tipologias de modelo de negócios em empresas de biotecnologia. 


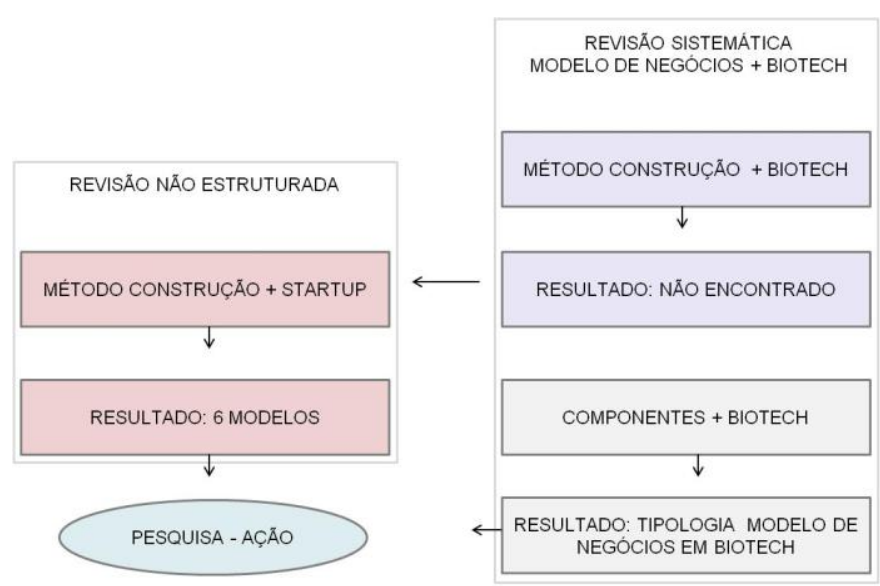

Figura 5: Gráfico esquemático do fluxo realizado da Revisão Bibliográfica: revisão sistemática e revisão não estruturada (Fonte: a autora).

\subsection{Modelo de negócios em startups}

O modelo de negócios descreve o racional de como uma organização cria, entrega e captura valor. O conceito de modelo de negócios foi inicialmente apresentado para definir o cliente, o valor e a forma de gerar faturamento em uma empresa (Drucker, 1994). O modelo de negócios foi resgatado, e seu termo criado, após a crise da indústria da internet quando foi atestado que um bom modelo de negócios permanece essencial para toda organização de sucesso para complementar uma estratégia competitiva, sendo um novo empreendimento ou empresa já estabelecida (Magretta, 2002).

Nesse estudo consideramos que o estudo de modelo de negócios compreende 4 parâmetros: conteúdo, abordagem, processo e contexto (Pedroso, 2016).

A dimensão do conteúdo considera questões tais como: as decisões tomadas no âmbito do modelo de negócios; como essas decisões podem ser classificadas (ou agrupadas em componentes); como essas decisões estão inter-relacionadas (arquitetura do modelo de negócios); e os modelos que podem ser considerados no desenho de novos modelos de negócios.

A arquitetura de modelo de negócios pode assumir as representações: canvas (Osterwalder \& Pigneur, 2010), triângulo mágico (Gassmann, Frankenberger, \& Csik, 
2014), lean canvas (Maurya, 2012) ou modelo de negócios em uma página (Pedroso, 2016).

- Canvas: o modelo de negócios abrange quatro áreas de um negócio: clientes, oferta, infraestrutura e viabilidade financeira. Esse modelo de negócios pode ser descrito por nove blocos que juntos mostram a lógica de como a empresa cria receita. Os blocos são: segmento de clientes, proposta de valor, canais, relacionamento com clientes, geração de receita, recursos-chave, atividades-chave, parcerias-chave, e estrutura de custos (Osterwalder \& Pigneur, 2010).

- Triângulo mágico: o modelo de negócios considera a proposta de valor, o modelo de geração de receita, a cadeia de valor e o segmento de clientes alvo. Dessa forma, essa arquitetura compreende o que é ofertado ao cliente, como a proposta de valor é criada, quem é o cliente alvo, e como a receita é criada - criando um padrão da triangulação fundamentado em: o que, quem, como e por que (Gassmann et al., 2014).

- lean canvas: o modelo de negócios considera elementos do ponto de vista do mercado (proposta de valor, vantagem, segmento de clientes, canais e fluxos de receita) e produto (proposta de valor, problema, solução, métricas chave e estrutura de custos). A representação desse modelo ocorre em caixas de texto em uma página tal como o de canvas (Maurya, 2012).

- modelo de negócios em uma página: o modelo de negócios considera duas camadas adicionais na representação do modelo de negócios: modelo de gestão e modelo de inovação que tem por fim sua complementação para a visualização completa do negócio. Dessa forma, em uma página visualiza-se o modelo de gestão (como organizar), modelo de inovação (como mudar), modelo de operações (como entregar), posicionamento estratégico (o que entregar), modelo de relacionamento com cliente (para quem entregar), e modelo econômico (como criar e capturar valor) (Pedroso, 2016).

Interessante notar que não existe um único modelo de negócios cabível a uma empresa, e sim, muitas oportunidades e opções que devemos desvendar para a melhor escolha do modelo (Osterwalder \& Pigneur, 2010). 
Com relação especificamente a empresas do tipo startup, devemos notar que a mesma não é uma versão menor de uma grande empresa, e sim uma organização temporária na busca de um modelo de negócios escalável, reprodutível e rentável (Blank \& Dorf, 2012).

Novas empresas falham apesar da presença de oportunidades de mercado, novas ideias de negócios, recursos adequados e empreendedores talentosos. Uma possível causa é o modelo que conduz o negócio (Morris, Schindehutteb \& Allen, 2005). Assim, é notável a necessidade de uma startup na adoção do modelo de negócios apropriado e de método adequado para obtê-lo.

Atualmente, encontramos globalmente diversos tipos de empresas startup que podem ser classificadas nos tipos: (1) pequeno negócio - onde a meta é o bom pagamento aos acionistas e lucro. Esse tipo representa a vasta maioria das empresas nos EUA, e geralmente refere-se a negócio de serviço; (2) startup escalável - baseada em tecnologia. A primeira fase desse tipo de empresa é buscar modelo de negócios escalável e reprodutível. Esse tipo requer investimento externo para expansão rápida, que pode resultar em retorno extraordinário para capital de risco; (3) startup "comprável" - baseada no baixo custo de desenvolvimento de aplicativos. Iniciada com baixo investimento de capital de risco e vendida a grande empresas; (4) empreendimento em grande empresa - baseada em inovação disruptiva; e (5) empreendimento social - baseada em soluções (Blank \& Dorf, 2012).

A maioria das startups não possuem processos estruturados para testar suas hipóteses de modelo de negócios (Blank \& Dorf, 2012). Há relato na literatura que o sucesso de uma startup pode ser projetado seguindo o processo correto, e que empreendedorismo é um tipo de gerenciamento (Ries, 2011). A literatura mostra alguns processos de construção de modelo de negócios.

\subsection{Construção de modelo de negócios em startup}

Os autores Osterwalder \& Pigneur (2010) apresentam um processo de construção de modelo de negócios com fundamentação no design que possui seis etapas: Insights do consumidor, Ideação, Pensamento Visual, Prototipação, Storytelling e Cenários. Como descrito a seguir. 
- Insights do consumidor: considera a perspectiva do consumidor como guia para todo o modelo de negócios informando as escolhas com relação à proposta de valor, canais de distribuição, relacionamentos com consumidor e geração de receita. Destarte o modelo de negócios é centralizado no consumidor e dessa forma responde a: qual trabalho o cliente necessita que seja realizado e como a empresa pode auxiliar, quais as aspirações do cliente e como a empresa pode auxiliar para a obtenção, como os clientes preferem ser abordados e como a empresa pode atender, qual relacionamento os clientes esperam que a empresa estabeleça com eles, e quais os valores os clientes realmente gostariam de pagar. O mapa de empatia é uma ferramenta que pode auxiliar nessas respostas. Essa ferramenta fornece estrutura às informações com relação a como o cliente: enxerga seu ambiente, escuta, pensa e sente, fala e faz, sua dor e seu ganho.

- Ideação: consiste na geração de ideia onde deve-se criar um grande número de ideias (ex. por brainstorming) e na síntese onde as ideias geradas são discutidas e reduzidas a um número de opções viáveis. As ideias podem ser geradas sob qualquer perspectiva de forma a ser dirigida por recursos, oferta, consumidor, finanças ou combinações entre os mesmos. Essa etapa pode ocorrer de diversas maneiras, sendo que uma abordagem geral é: composição de um time, imersão, expansão, seleção de critério e prototipação.

- Pensamento Visual: compreende a utilização indispensável de ferramentas visuais para construção e discussão do modelo de negócios.

- Prototipação: cria conceitos tangíveis e facilita a exploração de novas idéias. O protótipo do modelo de negócios pode assumir a forma de simples rascunho, conceito complexo como o canvas, caso de negócio ou teste de campo.

- Storytelling: auxilia na comunicação do modelo de negócios como tangível (ex. apresentação como novo, para investidores ou engajar funcionários).

- Cenários: considera a reflexão em como o modelo deve se desenvolver em certas condições, do ponto de vista do consumidor e ambientes onde o modelo de negócios irá competir.

A literatura apresenta um segundo processo de construção de modelo de negócios descrito por Blank \& Dorf (2012). Esse processo fundamenta-se no cliente. Mais especificamente, o processo visa a descoberta do cliente e compreende duas etapas para a busca do modelo de negócios: descoberta do cliente e validação do cliente, que prossegue na 
execução do modelo de negócios por criação do cliente e construção da empresa, tal como ilustrado na Figura 6.

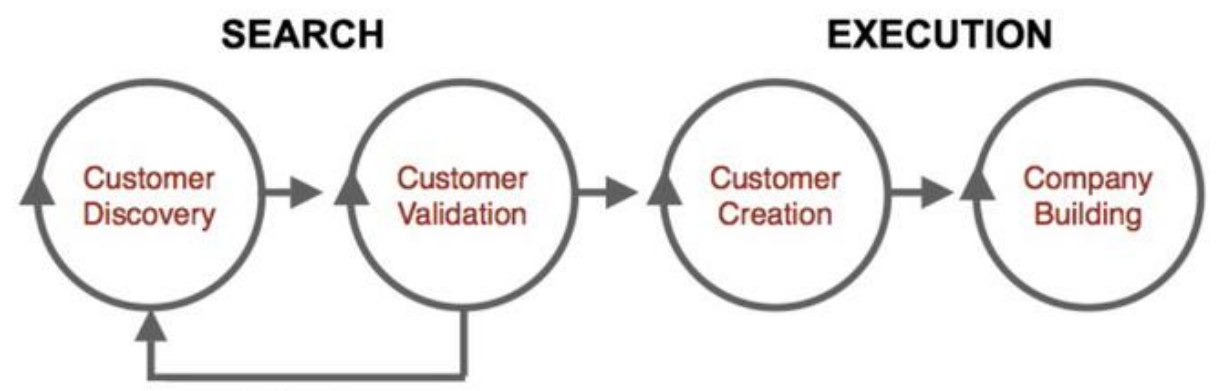

Pivot

Figura 6: Etapas de busca e execução do modelo de negócios (Fonte: Blank e Dorf, 2012, p.2).

A descoberta do cliente visa capturar a visão dos fundadores e a transformar em uma série de hipóteses de modelo de negócios. E então desenvolver um plano para testar as reações do cliente a essas hipóteses e torná-las em fatos.

A etapa de descoberta do cliente consiste de 4 fases, tal como descrito abaixo.

Fase 1: estabelecer a hipótese e esboçar o modelo de negócios. Nessa fase a visão dos fundadores é desconstruída em nove partes do modelo de negócios na arquitetura de canvas, e o time redige um sumário sobre cada uma das hipóteses, juntamente com uma lista de testes necessários pra provar ou não cada uma delas.

Fase 2: conduzir experimentos para testar a hipótese do problema em campo ("get out of the building to test the problem"). Auxilia a compreender quão importante é o problema ou pode se tornar. O objetivo é tornar hipóteses em fatos, e descartar se estiverem equivocados e substituir com novas hipóteses. No decorrer do processo, há ganho de compreensão profunda do negócio do cliente, fluxo de trabalho, organização e necessidades do produto. 
Fase 3: testar a solução apresentando a proposta de valor e produto minimamente viável para os clientes ("get out of the building to test the product solution") e comparar com as premissas estabelecidas anteriormente.

Fase 4: analisar os resultados dos experimentos, e verificar se possui: entendimento global dos problemas, paixões ou necessidades do cliente, confirmar se a proposta de valor resolve problemas, paixões ou necessidades, determinar que o volume de clientes existe para o produto, confirmar se a receita resultante poderá entregar um negócio rentável.

A etapa de validação do cliente possui o objetivo de testar se o modelo de negócios resultante é replicável e escalável. Caso o resultado seja negativo, o autor deve voltar a etapa de descoberta do cliente e excutar novamente alterando as premissas necessárias.

A etapa de validação do cliente consiste de 4 fases, tal como descrito abaixo.

Fase 1: preparar-se para iniciar as vendas consistindo das atividades de posicionamento do produto, materiais de vendas e marketing, contratação de responsável de vendas, criação de um plano de canal de distribuição, refinamento de um mapa de vendas e criação de um conselho consultivo.

Fase 2: Iniciar as vendas para responder se os clientes validarão o modelo de negócios. Essa tentativa para vendas será do produto inacabado e não provado sem uma estrutura de vendas para obter-se o feedback dos clientes.

Fase 3: Desenvolver posicionamento que ocorre quando a startup possui alguns pedidos de compra e informação do cliente suficiente para desenvolver e refinar o produto e posicionamento da startup.

Fase 4: Verificar com métricas que importam por meio de parar todas as atividades para conduzir análise detalhada para pivotar ou proceder e verificar que apesar do canal, validação do cliente está completa e a empresa sabe como escalar.

A validação do cliente está finalizada quando existem reais compras e usuários. A validação do cliente confirma que os clientes aceitarão o produto minimamente viável, prova que os clientes existem, torna predizível como acessá-los, e desenvolve uma plano escalável para engajar e vender mais. A validação nesse processo desenvolve o produto para se encaixar no mercado. 
Seguindo a busca pelo modelo de negócios, inicia-se a etapa de execução do mesmo que consistem das etapas descritas abaixo.

A etapa de criação de cliente corresponde ao início da execução. Há a criação da demanda do usuário final e direciona em canal de vendas para escalar o negócio.

A etapa de construção da empresa representa a organização de uma startup a uma empresa focada na execução de um modelo validado.

Um terceiro processo de construção de modelo de negócios denominado de navegador de modelo de negócios é descrito por Gassmann et al., 2014.

Esse processo é uma metodologia voltada para ação que permite qualquer empresa romper com a lógica dominante no setor e inovar no modelo de negócio. Ele tem mostrado ser efetivo em todos os tipos de organizações, setores e empresas, e fundamenta-se na ideia central de que os modelos de negócio bem-sucedidos podem ser construídos por meio da imitação criativa e da recombinação. Os autores afirmam que as empresas podem se inspirar no que já existem, visto que cerca de $90 \%$ de todas as inovações bem sucedidas do modelo de negócios, na verdade, recombinam os elementos do modelo de negócios existente. A inovação reside na compreensão, tradução, recombinação e transferência dos padrões de sucesso para seu próprio setor. Isso permite que uma empresa aprenda com outras e reinvente sua própria atividade.

O processo Navegador considera 55 padrões diferentes que estão no cerne do modelo de negócios que visam gerar ideias de novos negócios por transferir, combinar ou alavancar esses padrões. O mesmo é realizado por meio de quatro fases descritas a seguir.

- Iniciação: visa analisar o ecossistema para evidenciar algumas oportunidades de inovação. O modelo de negócios deve ser descrito com base nas quatro dimensões fundamentais da representação do tipo triângulo mágico, os participantes e as forças de mudança.

- Ideação: tem como objetivo adaptar os padrões pelo princípio da similaridade e da confrontação do modelo de negócios antigo com os 55 padrões. Dessa forma, a aplicação dos 55 padrões no modelo de negócios da empresa pode gerar novas ideias para seus negócios.

- Integração: visa detalhar o modelo de negócios de forma a gerar consistência interna (harmonia entre as suas dimensões) e externa (adequação ao ambiente da empresa). 
- Implementação: objetiva implementar o modelo de negócios desenhado nas três fases anteriores. É relevante testar, adaptar e introduzir no mercado.

Por questões de clareza do relato, os 55 modelos serão descritos no decorrer do capítulo 6, particularmente nas tabelas referentes aos modelos e submodelos de negócios.
4.4. Construção de modelo de negócios em startup fundamentada em alta tecnologia

Empresas startups podem alcançar o sucesso por meio da inovação. Com relação a esse tipo de startup, Blank \& Dorf, 2012 define que esse tipo de empreendimento possui riscos que podem ser enumerados em três classes: (1) risco cliente / mercado - onde é desconhecido se o mercado adotará o produto, (2) risco da inovação - onde é questionável se a tecnologia irá funcionar, (3) risco da inovação e mercado - onde se a tecnologia funcionar, se terá clientes. Nesses mercados, pode-se levar de 5 a 10 anos para obtenção de um produto e sua produção - como é o caso de empresas de biotecnologia.

Uma forma de gerenciar as incertezas do processo de inovação para desenvolver um modelo de negócios é descrito por Furr e Dyer, 2014. Nesse método, denominado método do inovador, é realizada uma série de ciclos de experimentação que resolvem as incertezas que envolvem o problema a ser resolvido, a solução proposta e o modelo de negócios. O método do inovador segue as etapas: insight, problema, solução e modelo de negócios. No decorrer dessas etapas são realizadas respectivamente as tarefas: degustação de surpresas, descoberta de trabalhos a serem feitos, prototipagem do produto mínimo fantástico e validação da estratégia go-to-market. A Figura 7 ilustra o referido método.

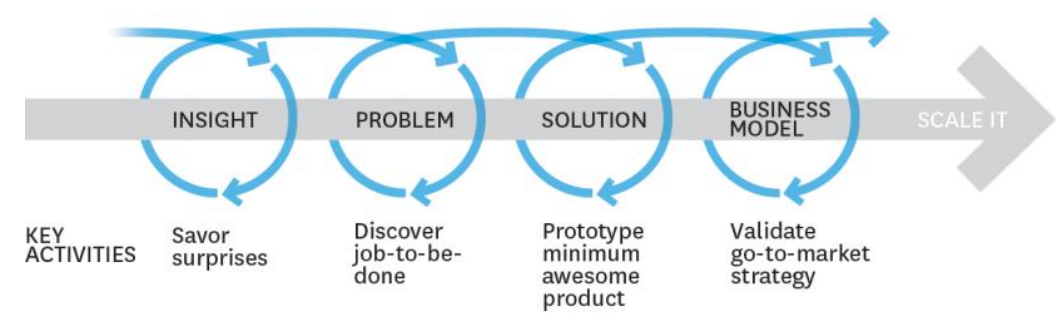

Figura 7: Ilustração das atividades chave em cada etapa do método do inovador (Fonte: Furr \& Dyer, 2014, p.30). 
Adicionalmente, Aulet, 2013 define dois tipos de empreendedorismo: (1) pequeno e médio empreendimento (SME, Small and Medium Enterprise), e (2) empreendimento orientado para inovação (IDE, Innovation-Driven Enterprise), com fundamentação em distintos objetivos intrísecos e necessidades .

De acordo com essa classificação, o empreendimento do tipo SME é geralmente iniciado para servir o mercado local, e cresce para ser um negócio de pequeno ou médio porte para atender esse mercado. Por outro lado, o empreendimento do tipo IDE é mais arriscado e ambicioso. Ele procura atender o mercado global, ou pelo menos regional. Esse tipo de negócio é construído com fundamentação em uma inovação (em tecnologia, processo, modelo de negócios) que proporcione uma vantagem competitiva com relação ao existente no mercado. Geralmente, a empresa inicia perdendo dinheiro, mas se atingir sucesso mostra crescimento exponencial em faturamento, fluxo de caixa e empregos gerados. Interessante notar que o investimento nesse tipo de empresa requer muito mais tempo para fornecer retorno que a SME.

Aulet, 2013 descreve um método baseado em 24 estágios reunidos em 6 diferentes etapas para a construção eficaz de um empreendimento do tipo IDE com base em inovação em tecnologia, tal como ilustrado nas Figuras 8 e 9. 


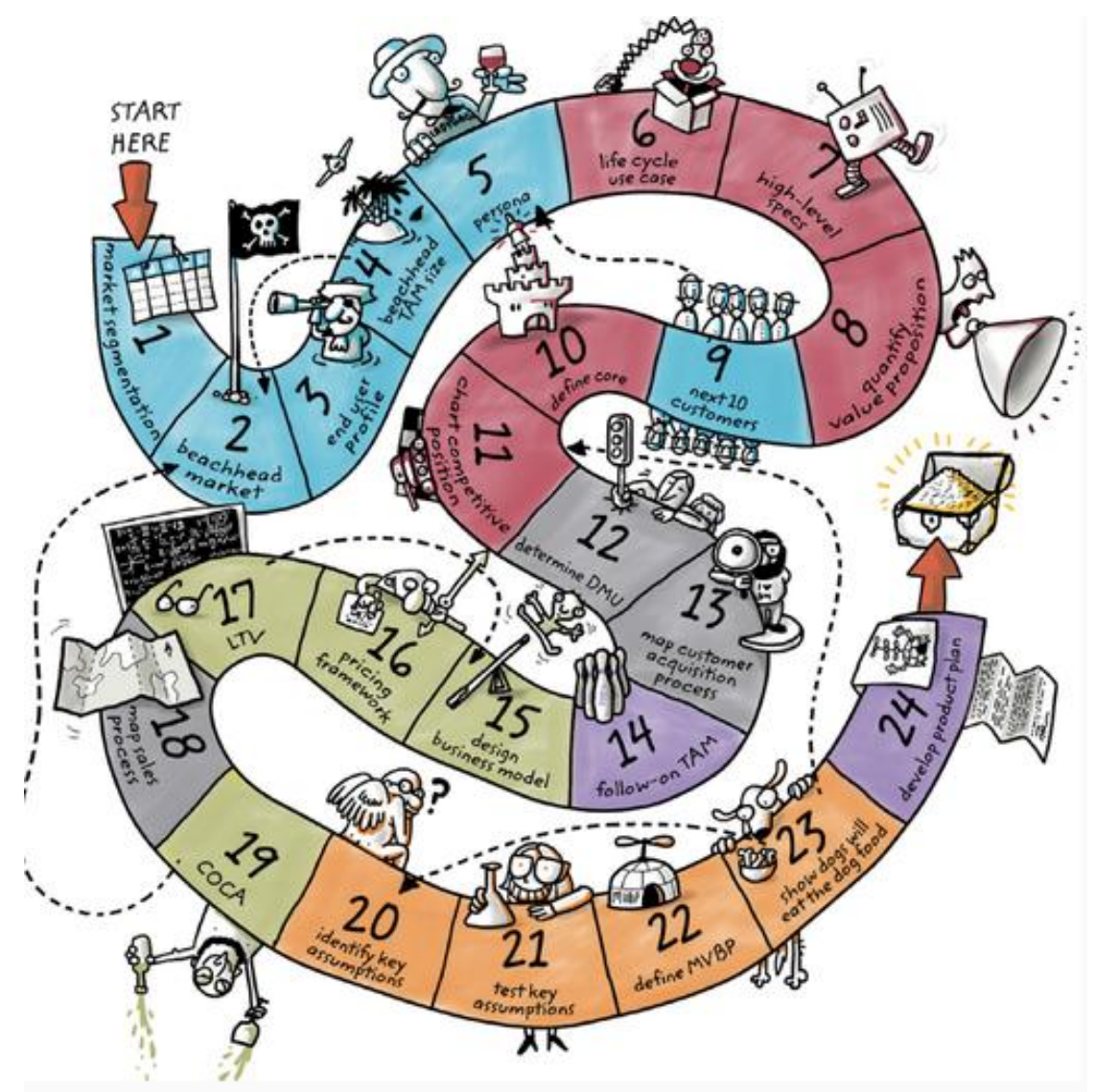

A

\begin{tabular}{|c|c|c|}
\hline $\begin{array}{l}\text { WHO IS YOUR } \\
\text { CUSTOMER? }\end{array}$ & $\begin{array}{l}\text { WHAT CAN YOU DO } \\
\text { FOR YOUR CUSTOMER? }\end{array}$ & $\begin{array}{l}\text { HOW DOES YOUR CUSTOMER } \\
\text { ACQUIRE YOUR PRODUCT? }\end{array}$ \\
\hline $\begin{array}{l}\text { Market } \\
\text { Segmenation }\end{array}$ & $\begin{array}{l}\text { (6) Full Life Cycle } \\
\text { Use Case }\end{array}$ & $\begin{array}{l}\text { 12) Decermine the Customer's } \\
\text { Decision:Making Unit (DMU) }\end{array}$ \\
\hline $\begin{array}{l}\text { Select a Beachhead } \\
\text { Market }\end{array}$ & $\begin{array}{l}\text { High-Lavel Product } \\
\text { Specification }\end{array}$ & 3 Map The Process to \\
\hline $\begin{array}{l}\text { Build an End User } \\
\text { Profile }\end{array}$ & $\begin{array}{l}\text { Quantfy the Value } \\
\text { Proposition }\end{array}$ & $\begin{array}{l}\text { (18) Map the Sales Process } \\
\text { to Acquire a Custeomer }\end{array}$ \\
\hline $\begin{array}{l}\text { Calculate che TAM Size for } \\
\text { the Beachhead Markes }\end{array}$ & $\begin{array}{l}\text { Define } \\
\text { Your Core }\end{array}$ & \\
\hline $\begin{array}{l}\text { Profile the Persone for } \\
\text { the Beachlhead Market }\end{array}$ & $\begin{array}{l}\text { Chart Your } \\
\text { Competiteve Position }\end{array}$ & \\
\hline $\begin{array}{l}\text { Idencifiy Your } \\
\text { Next } 10 \text { Customers }\end{array}$ & & \\
\hline $\begin{array}{l}\text { MOW DO YOU MAKE MONEY } \\
\text { OFF YOUR PRODUCT? }\end{array}$ & $\begin{array}{l}\text { HOW DO YOU DESIGN \& } \\
\text { BUILD YOUR PRODUCT? }\end{array}$ & $\begin{array}{l}\text { HOW DO YOU SCALE } \\
\text { YOUR BUSINESS? }\end{array}$ \\
\hline $\begin{array}{l}\text { Designa } \\
\text { Business Model }\end{array}$ & $\begin{array}{l}\text { O) Idencty Key } \\
\text { Assumptions }\end{array}$ & $\begin{array}{l}\text { (14) Calculare dhe TAM Size } \\
\text { for Follow-on Markers }\end{array}$ \\
\hline $\begin{array}{l}\text { Set Your Pricing } \\
\text { Framework }\end{array}$ & $\begin{array}{l}\text { Tess Key } \\
\text { Assumptions }\end{array}$ & 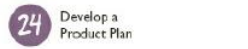 \\
\hline $\begin{array}{l}\text { Calculate che Lifetime Value } \\
\text { (ITV) of an Acquired Cuscomer }\end{array}$ & $\begin{array}{l}2 \text { Define the Minimurn Vable } \\
\text { Business Product (MVBP) }\end{array}$ & \\
\hline $\begin{array}{l}\text { Calculate the Cost of } \\
\text { Cistomer Acquistion (COCA) }\end{array}$ & $\begin{array}{l}\text { Show That "The Dogs } \\
\text { will Eat the Dog food" }\end{array}$ & \\
\hline
\end{tabular}

Figura 8: Método de 24 estágios (A) reunidos em 6 etapas (B) para obtenção de um empreendimento do tipo IDE (Fonte: Aulet, 2013, p. 26 e 27). 
A definição de modelo de negócios de uma empresa startup do tipo IDE é extremamente relevante para o sucesso e alcance de sua sustentabilidade financeira. No método descrito acima, a construção do modelo de negócios é finalizada na etapa 15 como descrito a seguir.

O autor considera a fase inicial de determinação de seu cliente alvo descritos nas 5 primeiros estágios como o mais relevante, a qual denomina de "a procura do cálice sagrado da especificidade" que parece ser o cerne da criação de valor. A figura 9 ilustra essa fase.

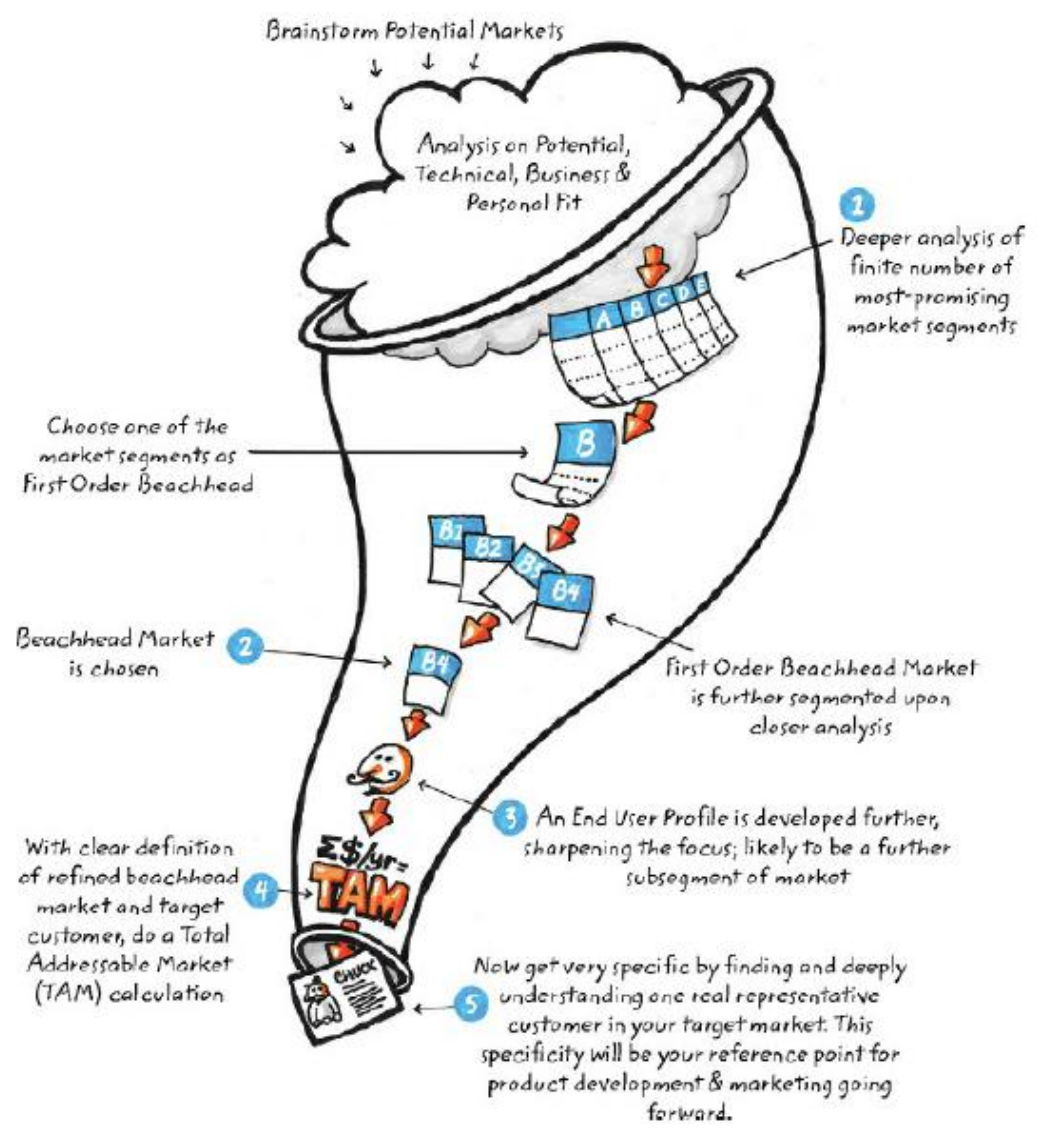

Figura 9: Método de 5 estágios para a procura do cálice sagrado da especificidade (Fonte: Aulet, 2013, p. 33).

De acordo com a etapa inicial, a construção de um empreendimento IDE deve seguir os estágios de: (1) segmentação de mercado, (2) seleção de mercado beachhead, (3) construção do perfil do consumidor final, (4) cálculo do tamanho do mercado endereçável total (TAM, total adressable market), (5) definição da Persona para o mercado beachhead. 
A primeira etapa, denominada de segmentação de mercado consiste em uma abordagem orientada ao consumidor final por meio do achado de uma necessidade não atendida do cliente, e a construção do negócio em torno disso. Essa abordagem leva em consideração que a criação de um produto inovador onde um mercado não existe é essencial para o sucesso de uma startup. A empresa terá recursos suficientes para expandir para mercados adjacentes quando tiver fornecido um produto superior para um grupo de clientes pagantes. Nota se que os recursos de empresas do tipo IDE são escassos na sua fase inicial de implantação, e assim devem ser empregados em novo mercado que possa dominar.

Nesse estágio, é realizado seguindo as fases: (1a) Brainstorm - com o objetivo de obter uma ampla lista de possíveis clientes e oportunidades de mercado. No caso de nova tecnologia há de se refletir em grande número de indústrias que poderiam se beneficiar do seu produto. O foco deve ser no consumidor final; (1b) seleção das oportunidades de forma a estreitar as opções em 6 a 12 mais interessantes, e (1c) pesquisa de mercado por meio de entrevista e observação dos consumidores para entender seus problemas.

A seleção do mercado beachhead deve ser realizada no estágio seguinte visto que a startup pode estabelecer mais facilmente uma posição forte no mercado e fluxo de caixa positivo se escolher um simples mercado - antes de exaurir seus recursos. O mercado beachhead é o mercado onde no momento em que a empresa conquistar a participação de mercado dominante terá força para conquistar os mercados adjacentes com ofertas distintas, construindo uma empresa maior. Interessante ressaltar que o mercado beachhead deve ser pequeno visto que o primeiro mercado serve como uma experiência de aprendizado sendo assim melhor ter alta exposição entre a base de clientes como ocorre em mercados menores. Esse mercado deve ser adicionalmente segmentado para a obtenção de oportunidade de mercado bem definido e homogêneo.

A construção do perfil do consumidor final é realizada na sequência para apontar a direção correta para estágios futuros e foco correto, ou seja, para especificidade.

A etapa seguinte irá determinar qual o faturamento anual que a empresa conquistará se atingir $100 \%$ de participação de mercado - TAM - a ser calculado considerando o primeiro mercado beachhead por meio de ambas as análises bottom-up e top-down. 
A definição da Persona proporciona os detalhes específicos sobre o consumidor primário em seu mercado beachhead com o objetivo de desenvolver um produto para atendê-lo. Essa definição deve ser ilustrada em meio de um tipo de fichamento.

Uma vez que foi obtida uma grande especificidade com relação ao consumidor final, e a empresa está focada no seu cliente-chave, é o momento de coletar detalhes específicos de como o consumidor irá utilizar esse produto. O objetivo é determinar como o produto da empresa se encaixa no valor de cadeia da Persona.

Essa etapa é composta dos estágios: (6) caso de ciclo de vida completo de uso. Representação visual que facilita a entender como o produto se encaixaria na cadeia de valor do cliente e quais seriam as barreiras para ele adotar o produto, (7) especificação detalhada, na forma de brochura, do produto voltado para o mercado beachhead onde será capaz de ganhar participação de mercado, (8) quantificação da proposição de valor por meio do alinhamento com as prioridades da Persona, (9) identificação, e entrevista, de próximos 10 clientes em sua Persona que permitirá selecionar a oportunidade escalável e validar as assunções anteriores (10) definição do negócio principal da empresa baseado na impossibilidade de replicação do produto por competidores. O mesmo deve ser fixo e deve torna-se continuamente forte no decorrer do processo, (11) definição da posição competitiva da empresa para validar o produto contra seus concorrentes reavaliando seu produto caso não esteja em posição superior.

Nesse estágio, a empresa deve estar confiante que a Persona terá valor substancial do seu produto que é único, ou seja, a criação de valor foi gerada. Na próxima etapa a empresa deve garantir sua confiança de que a Persona e seus próximos 10 consumidores irão comprar seu produto, e em seguida construir o modelo de negócios. Os estágios para cumprir esses objetivos são: (12) determinação da unidade de tomada de decisão do cliente (DMU, decision-making unit) para entender que toma a última decisão e quem influencia essa decisão, (13) mapeamento do processo de aquisição do cliente pagante para a definição de como o DMU decide comprar o produto e identifica obstáculos para sua venda, (14) cálculo do tamanho do mercado endereçável total (TAM) para mercados follow-on com o objetivo de rápida validação do mercado, e (15) construção do modelo de negócios.

As etapas posteriores estão focadas na avaliação financeira, construção do produto e escalabilidade da startup. Apesar de serem etapas posteriores a construção do modelo de 
negócios, é relavante enumerá-las como a seguir. A avaliação financeira é realizada por meio dos estágios: (16) definição do preço baseado em valor, (17) definição do LTV (lifetime value) que corresponde a margem bruta do produto (igual a preço subtraído do valor de custo de produção) no decorrer de um período de tempo específico de 5 anos. O mesmo não inclui valor despendido em pesquisa e desenvolvimento, administração, financeiro ou overhead, (18) mapeamento do processo de aquisição de um cliente, (19) cálculo do COCA (cost of client acquisition) no decorrer de um período de tempo específico de 5 anos. A relação entre COCA:LTV deve assumir um número de ao menos 3, para que a startup seja considerada promissora.Com relação a construção do produto, essa metodologia fundamenta-se nos estágios: (20) identificação das premissas principais que o produto deveria ter para que seja completo o suficiente para que o cliente ganhe valor adotando o formato de MVBP (minimun viable business product), (21) teste das premissas junto aos clientes, (22) definição do MVBP de acordo com a validação obtida no estágio anterior, (23) demonstração quantitativa que o cliente irá pagar pelo MVBP. Nesse momento o preço não é importante. O que deve ser mostrado é que os clientes alvo irão pagar pela adoção do produto, e (24) desenvolver o plano do produto de forma a planejar o produto para os próximos mercados centrados no seu core.

A autora desse trabalho identificou outro método de construção de modelo de negócios que pode ser aplicado a IDE que é descrito por Pedroso, 2018. Esse processo de análise, desenho e inovação de modelo de negócios adota a arquitetura (ou conteúdo) do modelo de negócios em uma página descrito por Pedroso, 2016.

As abordagens utilizadas no modelo de construção de modelo de negócios descrito por Pedroso, 2018 possuem foco no empreendedor que são visual intuitiva, escolhas estratégicas e recombinante, que correspondem ao desenho do modelo de negócios por técnicas visuais, escolhas estratégicas da empresa, e recombinação de padrões, respectivamente.

Esse processo consiste em três fases que seguem a lógica problema-solução-modelo de negócios: definição do problema, definição da solução e definição do modelo de negócios, tal como ilustrado na Figura 10.

- Fase 1: tem como objetivo a avaliação de oportunidades e escolhas por priorização.

- Fase 2: visa a geração de alternativas de solução e escolha por seleção

- Fase 3: tem como objetivo a geração de alternativas de modelo de negócios e escolhas por seleção. 


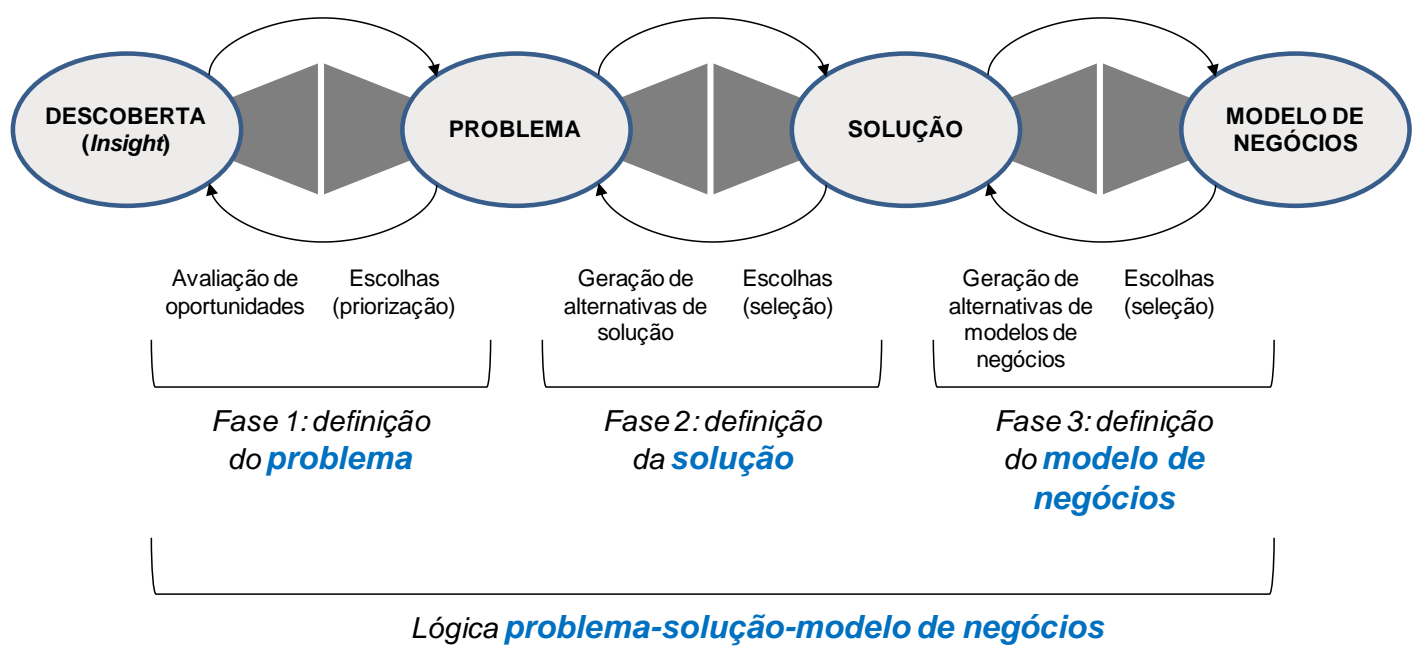

Figura 10: Fases do processo de construção de modelo de negócios descrito por Pedroso, 2018 (Fonte: Pedroso, 2018).

As três fases do processo podem ser agrupadas em 3 ciclos sendo que cada ciclo representa a validação de uma das fases, tal como descrito na figura 11 . O ciclo 1 corresponde a validação do problema, o ciclo 2 corresponde a validação da solução e o ciclo 3 a validação o modelo de negócio. 


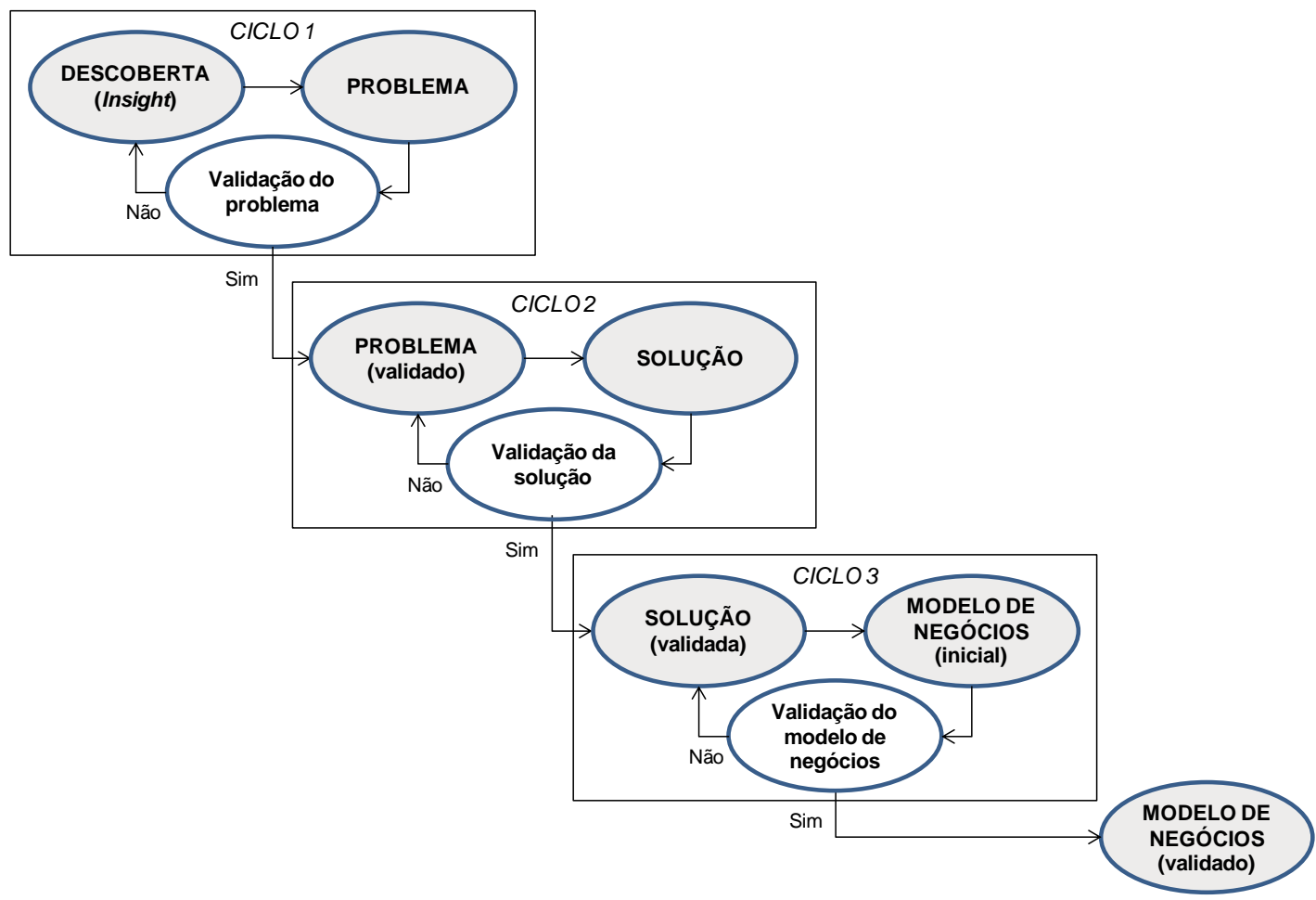

Figura 11: Ciclos do processo de construção de modelo de negócios descrito por Pedroso, 2018 (Fonte: Pedroso, 2018).

O processo completo percorre 21 etapas para resultar em um modelo de negócios, tal como ilustrado na Figura 12. Vale ressaltar que a fundamentação dos elementos dessas etapas não será individualmente considerada, e explanada, no presente capítulo, e sim ao longo do capítulo 6 (resultados) com o intuito de conferir maior fluidez da análise nesse trabalho. 


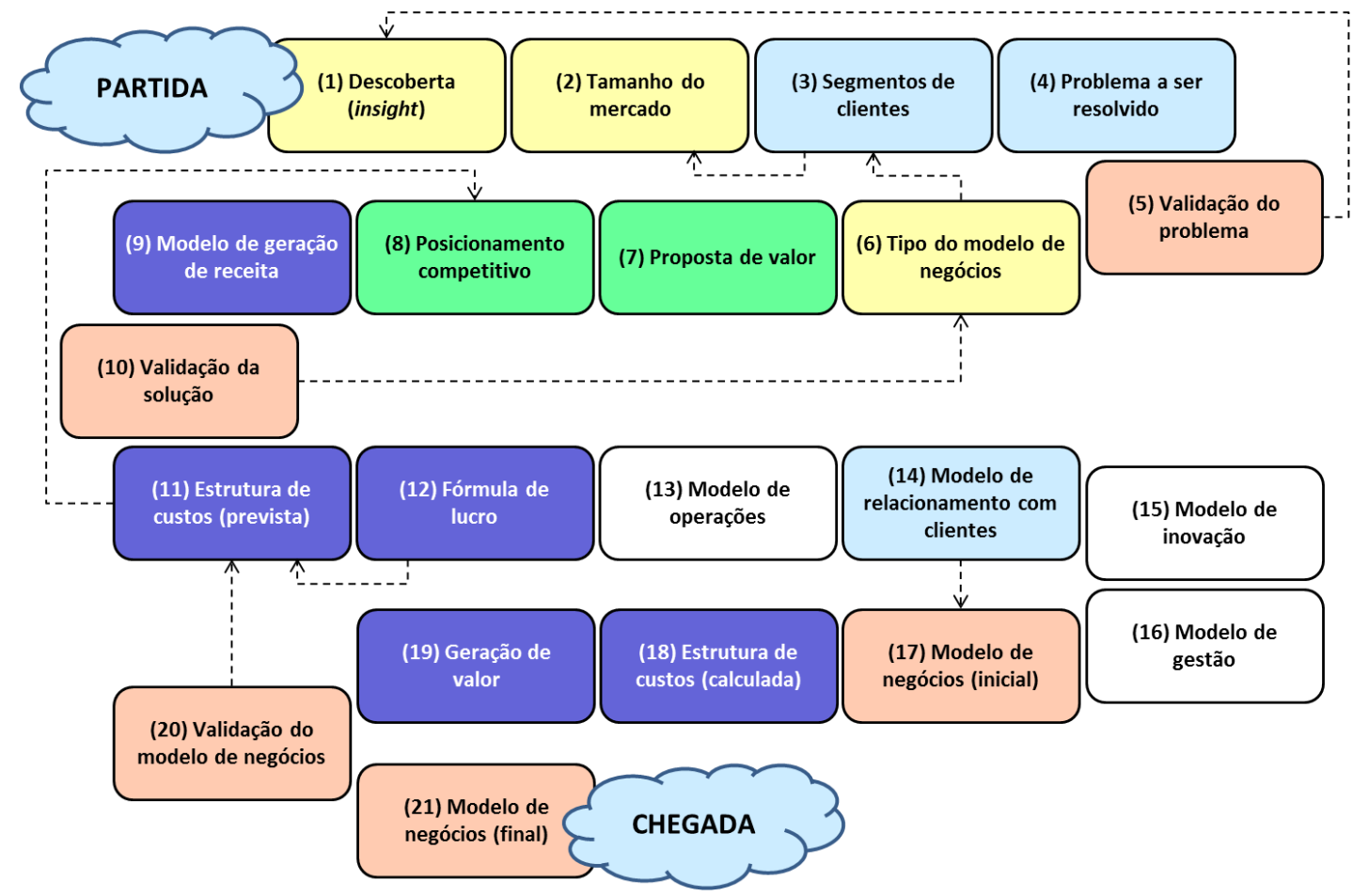

Figura 12: As 21 etapas do processo de construção de modelo de negócios descrito por Pedroso, 2018 (Fonte: Pedroso, 2018).

Uma análise comparativa entre os métodos de construção de modelo de negócios mostra que há similaridades em seus elementos e etapas (Figura 13).

Os métodos analisados nesse estudo tendem a considerar no seu processo a etapa de prospecção de ideias, ou oportunidades de negócio, que é denominado usualmente de insight. Dentre esses métodos, somente os descrito por Blank \& Dorf, 2012 e Gassmann et al., 2014 não o exploram. Os mesmos iniciam seu processo a partir de uma oportunidade previamente estabelecida. Vale ressaltar que o método descrito por Blank \& Dorf, 2012 estabelece no seu estágio inicial a definição de hipóteses ou premissas de todos componentes do modelo de negócios partindo do pressuposto que a oportunidade já foi selecionada pelos empreendedores.

A etapa denominada de ideação é essencial no método descrito por Osterwalder \& Pigneur, 2010. O método descrito por Aulet, 2013 inclui etapas com a mesma fundamentação da ideação que são as etapas de segmentação de mercado e especificação do produto. 
A etapa de descoberta do cliente é a fundamentação do método descrito por Blank \& Dorf, 2012, e premissas similares podem ser obervados no método definido por Aulet, 2013 (etapas 1 a 5), Furr \& Dyer, 2014 (job to be done) e Pedroso, 2018 (etapas 2 a 5).

A etapa de análise de cenários descrita no método apresentado por Osterwalder \& Pigneur, 2010, também é observada nos métodos de Blank \& Dorf, 2012 (descoberta do cliente), Aulet, 2013 (10 clientes) e Furr \& Dyer, 2014 (validação go to market).

A utilização de tipologia de modelo de negócios é a fundamentação do método descrito por Gassmann et al., 2014. A tipologia é utilizada no método de Pedroso, 2018 (etapas 13 a 21). Uma tipologia própria é utilizada por Aulet, 2013 (modelo de negócios).

As ferramentas de prototipação e MVP são utilizadas pelos métodos descritos por Osterwalder \& Pigneur, 2010 (prototipação), Blank \& Dorf, 2012 (descoberta do cliente), Aulet, 2013 (MVBP), e Furr \& Dyer, 2014 (solução). 


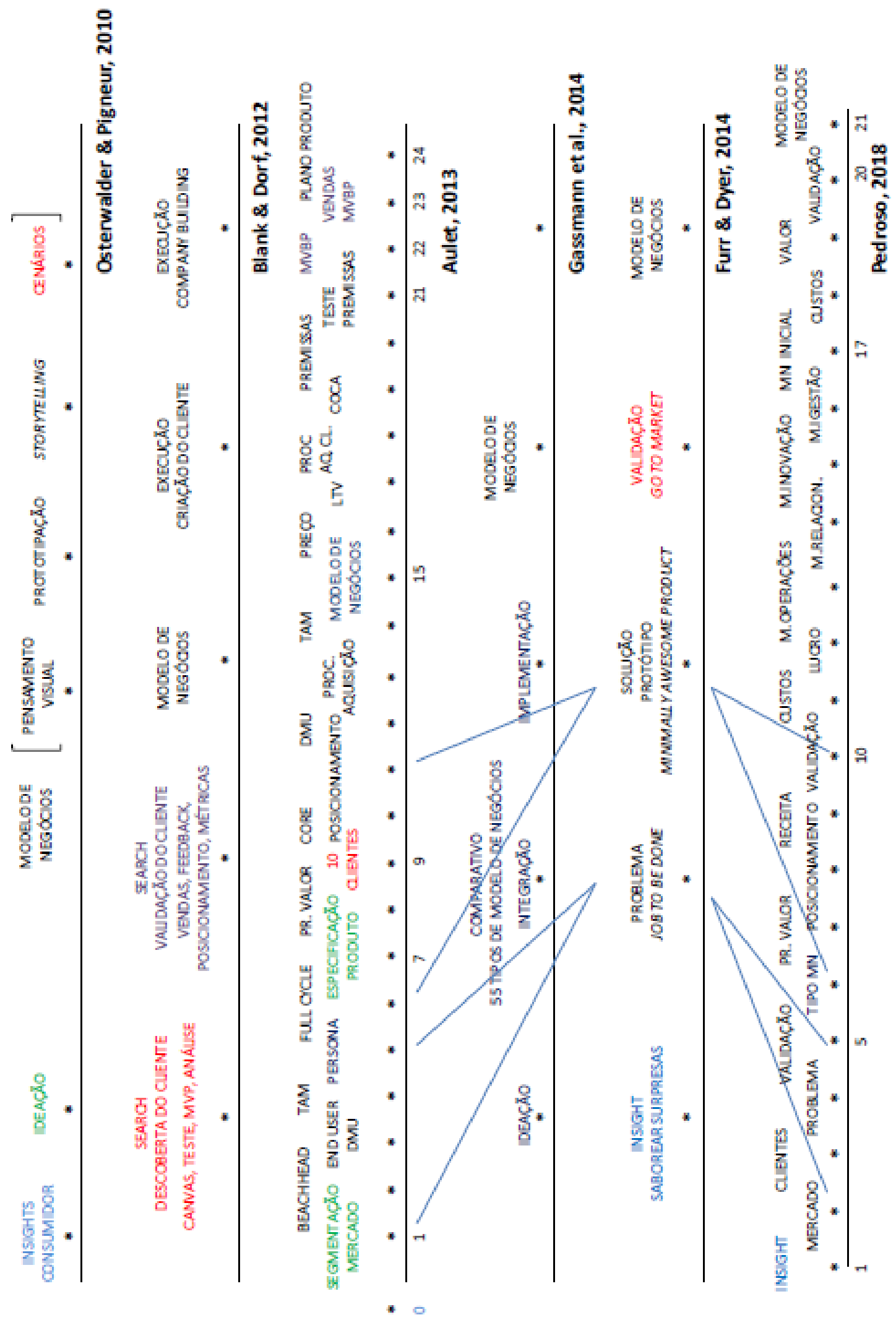

Figura 13: Gráfico comparativo dos métodos de construção de modelo de negócios em startups. 


\subsection{Construção de modelo de negócios em startups em biotecnologia}

Três características são particularmente importantes para distinguir o desenvolvimento da biotecnologia do desenvolvimento tecnológico de outros setores: (i) refere-se ao seu processo que é definido pelo uso de células e enzimas microbianas, animais ou vegetais para sintetizar, quebrar ou transformar material, (ii) possui uma alta dependência da pesquisa básica em biologia molecular, havendo uma conexão estreita entre a pesquisa científica básica e a biotecnologia comercial, e (iii) possui alto nível de incerteza e controvérsia social devido a engenharia genética e sua regulamentação (Bartholomew, 1997).

A biotecnologia, portanto, tem aplicação comercial em produtos e processos em uma ampla variedade de setores industriais, incluindo produtos farmacêuticos, produtos químicos, agricultura, aquicultura, processamento de alimentos, silvicultura e eliminação de resíduos, entre outros.

Atualmente, a biotecnologia é classificada com fundamento em sua aplicação em: (i) azul: marinha ou aquática, (ii) vermelha: processo médico, (iii) branca: processo industrial e (iv) verde: processos de agricultura.

A indústria da biotecnologia é o maior contribuidor para a economia americana. Similarmente, ao menos 20 países identificam a biotecnologia como crítica no seu futuro econômico e geração de empregos. A estimativa é que a receita total norte-americana gerada pela biotecnologia em 2012 tenha atingido pelo menos US\$ 324 bilhões - o que é equivalente a pelo menos $2 \%$ do produto interno bruto. As receitas totais compreendem três subsetores biotecnológicos: produtos biológicos (drogas) em US\$ 91 bilhões; culturas agrícolas (e sementes) em US\$ 128 bilhões; e produtos industriais (biocombustíveis, enzimas, biomateriais e bioquímicos) em U\$ 105 bilhões. Ao longo da última década, as receitas agregadas em biotecnologia cresceram em média a taxas anuais de $10 \%$, sendo maior do que a economia como um todo (Carlson, 2016).

No surgimento da indústria de biotecnologia, os modelos de negócio definidos pelas empresas pioneiras (ex Amgen, Millennium, Celera Genomics e Genentech) revolucionaram seu ambiente de maneira sem precedentes por meio da associação de pesquisa upstream, capital de risco e grandes empresas. Neste momento, as maiores empresas de biotecnologia geraram receita por meio da implantação de modelos de 
negócios simultâneos relacionados a clientes distintos (Sabatier, Mangematin \& Rousselle, 2010).

O modelo de negócios em empresas de biotecnologia foi primariamente definido em quatro tipos encontrados na Europa: (i) totalmente integrado com empresas farmacêuticas (FIPCO; fully integrated pharmacetuical company), (ii) produto, (iii) plataforma e (iv) híbrido (Fisken \& Rutherford, 2002).

A FIPCO é uma forma de modelo de negócios focado no desenvolvimento de produtos farmacêuticos, e ilustra os primeiros modelos de negócios em biotecnologia, e que foram adotados pelas empresas Amgen e Genetech (1976). Esse modelo é integrado verticalmente que apesar de maximizar o retorno financeiro também maximiza o risco associado e requer altos níveis de financiamento. A dificuldade das empresas de encontrar esse tipo de financiamento, fez com que o modelo de negócios evoluísse para outros tipos.

(ii) $\mathrm{O}$ modelo de produto é uma evolução do FIPCO e, que produtos são desenvolvidos que adquirem valor progressivo juntamente com o processo de desenvolvimento da droga, e são licenciados ou diretamente comercializados. A parceria entre empresas para o desenvolvimento do produto é comum para mitigar os altos riscos associados. Esse modelo é considerado comprovado - 19 empresas de 22 maiores empresas de biotecnologia no mundo em 2001 possuíam modelo de produto. Podemos citar a Shire Pharmaceutical como exemplo de empresa com modelo de produto.

(iii) $\mathrm{O}$ modelo de plataforma é um modelo mais recente datado do final da década de 80. Esse modelo envolve o desenvolvimento de uma plataforma e seu licenciamento, assinatura ou venda. Algumas empresas fundamentadas nesse modelo de negócios desenvolvem serviços especializados na plataforma proprietária. Esse modelo rapidamente se estabeleceu na Europa visto a necessidade de estabelecer receita em face de raridade de investidores venture capital. Podemos citar Celera e Qiagen como exemplos de empresas com modelo de plataforma.

(iv) $\mathrm{O}$ modelo híbrido é uma combinação entre os modelos de produto e plataforma que gera um portfólio de produtos. O mesmo consegue criar valor sustentável por meio da integração downstream. O mesmo tornou-se dominante na indústria. Podemos citar a Millenium como exemplo de empresa com modelo de plataforma híbrido. 
A Figura 14 ilustra as principais características do modelo de negócios que são do tipo Plataforma, Híbrido e Produto.

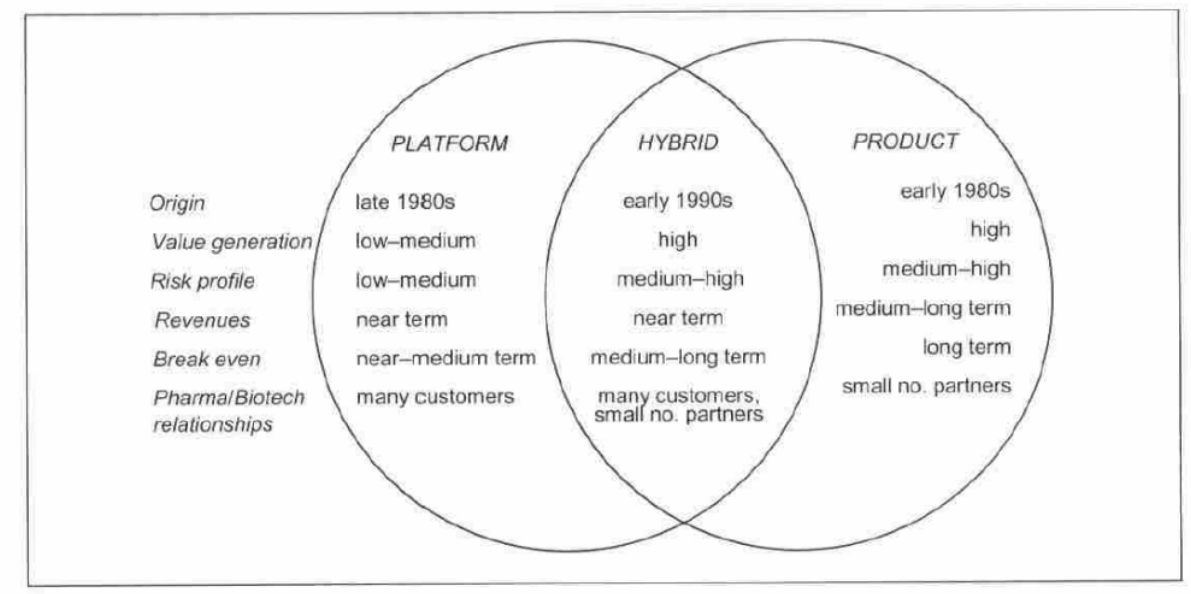

Figura 14: Ilustração das principais características do modelo de negócios do tipo Plataforma, Híbrido e Produto (Fonte: Fisken \& Rutherford, 2002).

Em outro estudo, Nosella, Petroni e Verbano (2006) descreve 5 modelos de negócios encontrados em startups italianas no setor de biotecnologia: (i) firmas novas biotech: desenvolvem o produto a partir de pesquisa até sua otimização, e licencia o mesmo; (ii) firmas integradas: possuem grande portfólio de produtos e integra as atividades primárias da cadeia de valor que inclui identificação do alvo, otimização e comercialização do produto, (iii) empresas de manufatura: desenvolvem o produto a partir das fases mais avançadas do desenvolvimento tais como produção e comercialização, (iv) biotech fornecedora: desenvolvimento industrial e produção de produtos biotecnológicos e fornecimento para outras empresas e (v) firmas de serviço: comercializa serviços de pesquisa para outras empresas.

Ambos os autores mencionados acima definem modelo de negócios entre empresas que: (1) realizam todas as atividades no processo inovador / cadeia de valor, (2) proporcionam tecnologia de suporte ou serviços ao processo, e (3) que a única atividade é desenvolvimento de produto (Tölle \& Kappfjell Herbst, 2016).

Interessante notar que iniciar e sustentar uma startup fundamentada em P\&D, particularmente no setor de biotecnologia, requer um modelo de negócios que aperfeiçoe estratégias de financiamento, mercado e operacional (Tsai \& Erickson, 2006). De fato, 
outros autores sugerem que diferenciar o modelo de negócios na indústria de tecnologia da saúde é de grande relevância (Lehoux, Daudelin, Williams-Jones, Denis \& Longo, 2014).

A estratégia de financiamento é de grande relevância para a startup em biotecnologia em face do longo desenvolvimento do produto e consequente retardamento do início da geração de receita, que é intrínseco dessa indústria. O financiamento é necessário para gerar ganhos para operações, e assim direcionar o desenvolvimento do produto e estratégias de negócio. Para a obtenção de financiamento, geralmente as empresas em biotecnologia contam com: (i) capital de risco, (ii) parceria com grandes farmacêuticas ou corporações na área de biociências, (iii) capital de investidores anjo, e/ou (iv) financiamento/incentivos do governo (Tsai \& Erickson, 2006).

Atualmente, as empresas de menor porte gerenciam o portfólio de modelo de negócios de forma a desenvolver o valor de mercado de suas atividades para geração de fluxo e receita, e assim equilibrar as incertezas e o longo período entre o investimento e a obtenção de receita que são típicos do setor de biotecnologia (Sabatier, Mangematin\& Rousselle, 2010).

De acordo com a disponibilidade das opções de financiamento, as empresas de biotecnologia geralmente contem um dos modelos de negócios a seguir executados com planos estratégicos: (i) Construção: geração de receita por meio do desenvolvimento interno de um produto (in house) por meio das fases de pesquisa (bancada) até a aprovação de mercado, (ii) Licenciamento: geração de receita por meio de alianças estratégicas, parcerias e contratos de licenciamento, e (iii) Comercialização: geração de receita por meio de comercialização, joint venture ou estratégias de saída Interessante notar que os três modelos podem ser utilizados por uma mesma empresa (Tsai \& Erickson, 2006).

De fato, observa-se que algumas startups em biotecnologia adotam um portfólio diversificado de modelos de negócios visando maximizar a captação de valor do seu know how e das suas atividades associadas à $\mathrm{P} \& \mathrm{D}$. $\mathrm{O}$ equilíbrio entre os modelos de negócio é determinante para a geração de receita a curto e médio prazo, para subsidiar o longo prazo intrínseco ao desenvolvimento do negócio derivado de P\&D em biotecnologia (Sabatier, Mangematin\& Rousselle, 2010). 
Foi descrito que seis modelos de negócios foram observados em quatro empresas de biotecnologia de pequeno porte na Europa, que são: (i) desenvolvimento virtual, (ii) colaboração para descoberta, (iii) reposicionamento de produto, (iv) corretagem de tecnologia, (v) plataforma tecnológica, e (vi) terceirização de manufatura. Dentre as quatro empresas analisadas, três possuem dois ou mais modelos de negócios alinhados com a orquestração de seu know how e atividades de P\&D.

Essas empresas mostram que os modelos de negócio podem ser equilibrados para assegurar a geração de receita em curto ou médio prazo. Isso é importante para pequenas empresas, em face da dificuldade que enfrentam em sobreviver um longo período (média de 12 anos) sem volume de negócios, e lucro, referentes ao produto inovador. Esse atraso entre investimento e primeira geração de receita leva a rejeição por investidores que podem obter retorno do investimento em prazos curtos e médios em outras áreas (Sabatier, Mangematin \& Rousselle, 2010). Um portfólio diferenciado de modelo de negócios visa suprir essa dificuldade na obtenção de investimentos, e gerar receita em curto e médio prazos.

Cenários de modelo de negócios alternativos podem emergir da análise de: diferencial técnico, e da monetização e potencial de mercado do portfólio atual e pipeline. Assegurar a propriedade intelectual a tecnologias é uma maneira frequente de alcançar tais objetivos (Tsai \& Erickson, 2006).

Em um primeiro momento, o sistema para monetização da propriedade intelectual nas empresas de biotecnologia parece ter funcionado muito bem com o intuito de gerenciamento dos altos riscos e longa duração dos investimentos desde seu primeiro modelo - empresa Genetech em 1978. Nesse caso específico houve pela primeira vez a terceirização de um programa proprietário de $\mathrm{P} \& \mathrm{D}$ para uma empresa privada com o objetivo final na obtenção de lucro. O mercado de Know-how foi inaugurado. Contudo, uma análise detalhada sugere a existência de falhas no sistema que impede o desenvolvimento maior no setor de biotecnologia baseado no fato de que a monetização da propriedade intelectual resulta no isolamento de setores de P\&D que necessitam de integração para seu pleno avanço (Pisano, 2006). Portanto, esse autor sugere ser necessária uma nova arquitetura na estrutura de empresas de biotecnologia como também uma adaptação e inovação nos modelos de negócio relacionados a esse setor. 
Todavia, Rhyne, 2009 sugere que o modelo de negócios em empresas de biotecnologia deve contemplar uma forte equipe gerencial, propriedade intelectual e acesso a financiamento, uma vez que são fatores críticos de sucesso em empresas de biotecnologia no setor de desenvolvimento de drogas. Interessante ressaltar que o autor destaca que o design ideal de modelo de negócios nesse setor deve contemplar: produto efetivo com custo terapêutico eficiente, forte propriedade intelectual, enquadramento no portfólio de uma grande empresa farmacêutica, e um produto (diagnóstico) para proporcionar fluxo de caixa para financiamento de P\&D.

A construção de modelo de negócios em startups escandinavas no setor de biotecnologia foi analisada no que refere aos blocos de construção do modelo de negócios, tais como atividades chave, recursos chave, proposição de valor, clientes, relacionamento com clientes, canais, parcerias chave, receita e estrutura de custos (Tölle \& Kappfjell Herb, 2016). Os resultados mostram que há particularidades em startups farma e não farma, tal como mostrado na figura 15.

\begin{tabular}{|l|l|l|}
\hline Building Block & $\begin{array}{l}\text { The Pharma Business } \\
\text { Model }\end{array}$ & $\begin{array}{l}\text { The Non-Pharma Business } \\
\text { Model }\end{array}$ \\
\hline Key activities & $\begin{array}{l}\text { R\&D } \\
\text { Financing }\end{array}$ & $\begin{array}{l}\text { R\&D } \\
\text { Financing } \\
\text { Marketing and sales } \\
\text { Production }\end{array}$ \\
\hline Key resources & $\begin{array}{l}\text { Patent } \\
\text { Capital } \\
\text { Network } \\
\text { Know-how in R\&D }\end{array}$ & $\begin{array}{l}\text { Patent } \\
\text { Capital } \\
\text { Network } \\
\text { Know-how in R\&D } \\
\text { Know-how in Marketing } \\
\text { Know-how in Production }\end{array}$ \\
\hline Value proposition [VP] & Defining VP takes years & $\begin{array}{l}\text { Defining VP relatively short, } \\
\text { since R\&D can happen at } \\
\text { University }\end{array}$ \\
\hline Customer segments & $\begin{array}{l}\text { Big pharmaceuticals } \\
\text { (distributors) }\end{array}$ & $\begin{array}{l}\text { Distributors and end users } \\
\text { (end users = businesses) }\end{array}$ \\
\hline Customer relationships & $\begin{array}{l}\text { Personal } \\
\text { Distant } \\
\text { One-time transaction } \\
\text { Short-term }\end{array}$ & $\begin{array}{l}\text { Personal } \\
\text { Close } \\
\text { Continuous collaboration } \\
\text { Long-term }\end{array}$ \\
\hline Revenue Streams & $\begin{array}{l}\text { Conferences } \\
\text { Personal references }\end{array}$ & $\begin{array}{l}\text { Conferences } \\
\text { Personal references } \\
\text { Word of Mouth }\end{array}$ \\
\hline Channels & Private funding & $\begin{array}{l}\text { University } \\
\text { Parent company } \\
\text { Government } \\
\text { Research Institutes } \\
\text { Customers } \\
\text { Suppliers }\end{array}$ \\
\hline Cost structure & $\begin{array}{l}\text { Private funding } \\
\text { Government funding } \\
\text { Sales }\end{array}$ \\
\hline CROnture capitalists & $\begin{array}{l}\text { R\&D (product development), } \\
\text { Marketing }\end{array}$ \\
\hline & R\&D (clinical trials) & \\
\hline
\end{tabular}

Figura 15: Blocos de construção do modelo de negócios e suas características em startups escandinavas de biotecnologia (Fonte: Tölle \& Kappfjell Herb, 2016). 
O diagnóstico molecular é um segmento da biotecnologia, também denominado de diagnóstico in vitro. O diagnóstico molecular é resultado de avanços de conhecimento na biomedicina que permitem associar genética, expressão gênica e diagnóstico (Kurtzman, 2005). O principal mercado de diagnósticos moleculares está associado ao mercado de saúde humana que engloba diagnósticos para doenças infecciosas, doenças crônicas, doenças sexualmente transmissíveis, oncologia e testes genéticos (Miller, 2014). Tais diagnósticos visam permitir o tratamento de paciente de maneira personalizada e mais eficiente. Contudo, startups em diagnósticos geralmente apresentavam dificuldades na obtenção de financiamento visto que seus modelos de negócios não eram compreendidos ou apreciados por investidores de capital de risco (Kurtzman, 2005).

Atualmente, um modelo de negócio mais atrativo para esse setor fundamenta-se em uma plataforma tecnológica capaz de agregar um portfólio de diagnósticos resultando em rápido movimento do processo de $\mathrm{P} \& \mathrm{D}$ para o lançamento comercial. Nesse caso, a receita pode ser gerada precocemente por meio de: (i) realização de testes em laboratórios de referência onde as decisões são realizadas para comercialização dos testes, (ii) desenvolvimento de uma parceria com manufatores de diagnósticos in vitro, ou (iii) licenciamento da tecnologia. De fato, esse segmento tornou-se atrativo para investidores.

Outra possível estratégia para o segmento de diagnósticos moleculares é um modelo de negócio que associa produto e serviço, onde as empresas podem se capitalizar por meio de diagnósticos únicos e participação nas margens do serviço.

Na literatura há exemplos de empresas de diagnóstico que apresentam modelos de negócio de sucesso: ViroLogic, XDx e Genomic Health (Kurtzman, 2005), tal como descrito a seguir.

A empresa ViroLogic possui um laboratório referência estabelecido para análise de amostras de paciente e um serviço para auxiliar empresas de biofarmacêuticos a desenvolver tratamento para HIV e câncer. A empresa gerou receita de U\$36 milhões em 2004, e possui um mercado de capitalização de mais de U\$300 milhões.

Por outro lado, a empresa XDx aplica tecnologias de biologia molecular (ex. microarray, realtime polymerase chain reaction) para desenvolver novas formas para 
monitoramento do sistema imune que foi contemplado com financiamento de U\$20 milhões.

Exemplo de sucesso, a empresa Genomic Health é responsável pela comercialização do teste Oncotype DX que mensura a expressão de genes selecionados no câncer de mama como um teste preditivo que auxilia o médico no gerenciamento do câncer recém-diagnosticado.

Em face do acima exposto, a autora resume a tipologia de modelo de negócios encontrada em empresas de biotecnologia tal como mostrado na figura 16.

\begin{tabular}{|c|c|c|c|}
\hline FONTE & APLICAÇÃO & TIPO & DEFINIÇÃO \\
\hline \multirow{4}{*}{ Fisken \& Rutherford, 2002} & \multirow{4}{*}{$\begin{array}{l}\text { MODELO DE OPERAÇÃO } \\
\text { MODELO ECONÔMICO }\end{array}$} & $\begin{array}{c}\text { FIPCO } \\
\text { (fully integrated pharmacetuical company) }\end{array}$ & integrado verticalmente \\
\hline & & Produto & $\begin{array}{c}\text { avanço no desenvolvimento para comercializar } \\
\text { ou licenciar produto acabado }\end{array}$ \\
\hline & & Plataforma & $\begin{array}{l}\text { plataforma tecnológica proprietária para } \\
\text { licenciamento, assinatura ou venda }\end{array}$ \\
\hline & & Híbrido & $\begin{array}{c}\text { produto + plataforma com integração } \\
\text { downstream }\end{array}$ \\
\hline \multirow{5}{*}{ Nosella, Petroni e Verbano (2006) } & \multirow{5}{*}{$\begin{array}{l}\text { MODELO DE OPERAÇÃO } \\
\text { MODELO ECONÔMICO }\end{array}$} & Novas & $\begin{array}{c}\text { desenvolvimento do produto a partir da pesquisa } \\
\text { até sua otimização, ou licenciamento }\end{array}$ \\
\hline & & Integradas & $\begin{array}{c}\text { grande portfólio de produtos e integração das } \\
\text { atividades primárias da cadeia de valor que inclui } \\
\text { identificação do alvo, otimização e } \\
\text { comercialização do produto }\end{array}$ \\
\hline & & Manufatura & $\begin{array}{c}\text { desenvolvimento do produto a partir das fases } \\
\text { mais avançadas do desenvolvimento tais como } \\
\text { produção e comercialização }\end{array}$ \\
\hline & & Fornecedora & $\begin{array}{l}\text { desenvolvimento industrial, produção e } \\
\text { fornecimento para outras empresas }\end{array}$ \\
\hline & & Serviço & $\begin{array}{l}\text { comercialização de serviços de pesquisa para } \\
\text { outras e mpresas. }\end{array}$ \\
\hline \multirow{3}{*}{ Tölle \& Kappfjell Herbst, 2016} & \multirow{3}{*}{ MODELO DE OPERAÇÃO } & NA & $\begin{array}{l}\text { realização de todas as atividades no processo } \\
\text { inovador / cadeia de valor }\end{array}$ \\
\hline & & NA & $\begin{array}{l}\text { fornecimento ao processo de tecnologia de } \\
\text { suporte ou serviços }\end{array}$ \\
\hline & & NA & a única atividade é o desenvolvimento de produto \\
\hline \multirow{6}{*}{ Sabatier, Mangematin\& Rousselle, 2010} & \multirow{6}{*}{ MODELO DE OPERAÇÃO } & Desenvolvimento virtual & \\
\hline & & Colaboração para descoberta & \\
\hline & & Reposicionamento de produto & \\
\hline & & Corretagem de tecnologia & \\
\hline & & Plataforma tecnológica & \\
\hline & & Terceirização de manufatura & \\
\hline \multirow{3}{*}{ Tsai \& Erickson, 2006} & \multirow{3}{*}{ MODELO ECONÔMICO } & Construção & $\begin{array}{c}\text { geração de receita por meio do desenvolvimento } \\
\text { interno de um produto (in house) por meio das } \\
\text { fases de pesquisa (bancada) até a aprovação de } \\
\text { mercado }\end{array}$ \\
\hline & & Licenciamento & $\begin{array}{l}\text { geração de receita por meio de alianças } \\
\text { estratégicas, parcerias e contratos de } \\
\text { licenciamento }\end{array}$ \\
\hline & & Comercialização & $\begin{array}{l}\text { geração de receita por meio de comercialização, } \\
\text { joint ventur e ou estratégias de saída. } \\
\text { Interessante notar que os três modelos podem } \\
\text { ser utilizados por uma mesma empresa. }\end{array}$ \\
\hline
\end{tabular}

Figura 16: Tipologia de modelo de negócios em biotecnologia (Fonte: a autora). 
A autora observou que a tipologia em biotecnologia é aplicada somente aos modelos de operação e econômico. Tal restrição pode ser relacionada à priorização das empresas em biotecnologia na otimização de seus processos e operação, e geração de receita.

\section{MÉTODO DE PESQUISA}

Como acima discutido, faz-se relevante analisar a aplicabilidade de um método para a construção de modelo de negócios para a construção de modelo de negócios de IDE em empresas startups de biotecnologia, mais especificamente em startups brasileiras considerando as particularidades de empresas no setor de biotecnologia e do mercado brasileiro.

O método selecionado para esse estudo foi o descrito por Pedroso, 2018 por ser a princípio uma metodologia aplicável a IDE, ser orientado especificamente para a construção de modelo de negócios, e que contempla uma arquitetura de modelo de negócios com duas dimensões adicionais (modelo de gestão e modelo de inovação) que não são contempladas nos demais processos.

Para o desenvolvimento do presente estudo foi eleita a condução de uma pesquisa de caráter exploratória e natureza empírica de enfoque qualitativo (Bryman, 2003; Gil, 2002; Zikmund, Babin, Carr, \& Griffin, 2013). A pesquisa exploratória possui a finalidade de aprofundar o conhecimento sobre o problema a fim de torná-lo evidente ou construir hipóteses (Gil, 2002).

$\mathrm{Na}$ pesquisa qualitativa, diferentemente da quantitativa, o pesquisador busca compreender os fenômenos observando-os, interpretando-os e descrevendo-os. Dentre os métodos empregados na pesquisa qualitativa destacam-se o estudo de caso e a pesquisa-ação. A pesquisa-ação é um dos métodos qualitativos que pode ser empregado para que o pesquisador aprofunde seus conhecimentos acerca de um fenômeno e estabeleça questões de pesquisa mais pertinentes (Mello, Turrioni, Xavier, \& Campos, 2012).

A figura 17 ilustra o procedimento metodológico adotado nesse trabalho. A partir da questão de pesquisa descrita no item 2.2, foi realizada a revisão bibliográfica. A revisão bibliográfica fornece subsídios com dados secundários para a pesquisa de campo, a ser realizada na forma de pesquisa-ação, e dos resultados. Os subsídios foram o fundamento para a preparação das fases de diagnóstico, planejamento, ação e avaliação da pesquisa-ação. 
A pesquisa-ação segue por ciclos contínuos de diagnóstico, planejamento, ação e avaliação onde foram munidos de subsídios por meio da revisão bibliográfica durante todo o estudo. Os resultados obtidos na pesquisa são mostrados de acordo com a confrontação da teoria com a prática. Mais especificamente, os resultados são revelados pela avaliação oriunda dos ciclos da pesquisa-ação, todas as fases da pesquisa-ação e confronto com a revisão bibliográfica. Por fim, foram realizadas as conclusões e o retorno à questão de pesquisa.

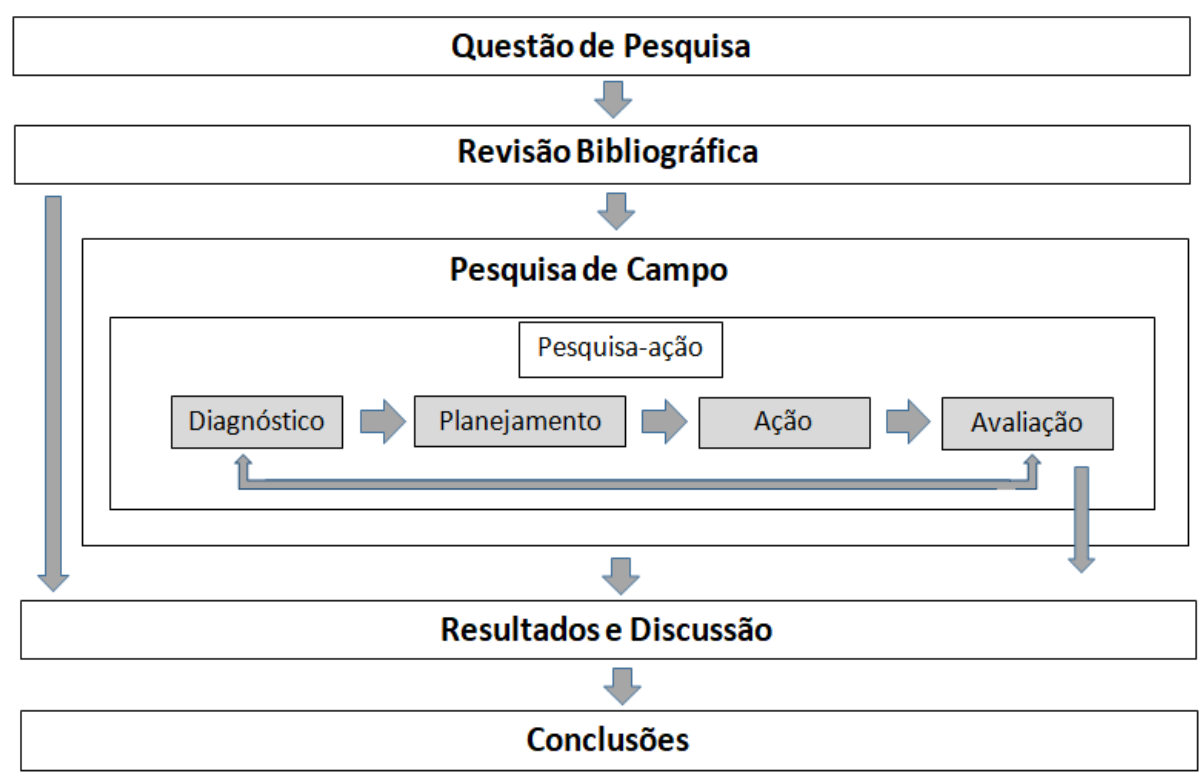

Figura 17. Ilustração do procedimento metodológico (Fonte: a autora).

\subsection{Matriz de Amarração Metodológica}

O trabalho seguiu o descrito no quadro teoria e prático ilustrado pela matriz de amarração metodológica entre a teoria, o referencial teórico, a prática recuperada pela pesquisa de campo, e a correlação com os objetivos previamente definidos, denominado pela autora como matriz de amarração metodológica planejada, tal como descrito na Figura 18. 


\begin{tabular}{|c|c|c|c|c|}
\hline \multicolumn{2}{|c|}{ OBJETIVOS } & \multirow{2}{*}{\multicolumn{2}{|c|}{ REVISÃO BIBLIOGRÁFICA }} & \multirow{2}{*}{ PESQUISA DE CAMPO } \\
\hline Objetivo Principal & Objetivos Específicos & & & \\
\hline \multirow{3}{*}{$\begin{array}{l}\text { Como desenvolver } \\
\text { o modelo de } \\
\text { negócios de uma } \\
\text { startup de } \\
\text { biotecnologia de } \\
\text { diagnóstico } \\
\text { molecular no } \\
\text { mercado } \\
\text { brasileiro? }\end{array}$} & $\begin{array}{c}\text { Identificação de } \\
\text { métodos para a } \\
\text { construção de modelos } \\
\text { de negócios em } \\
\text { empresa startup de } \\
\text { biotecnologia. }\end{array}$ & $\begin{array}{c}\text { Revisão } \\
\text { sistemática: } \\
\text { modelo de } \\
\text { negócios + } \\
\text { biotecnologia }\end{array}$ & $\begin{array}{c}\text { Revisão não } \\
\text { estruturada: } \\
\text { método de construção } \\
\text { modelo de negócios + } \\
\text { startup }\end{array}$ & \\
\hline & $\begin{array}{c}\text { Seleção de um método } \\
\text { para a construção de } \\
\text { modelo de negócios } \\
\text { para a intervenção em } \\
\text { uma empresa startup de } \\
\text { biotecnologia de } \\
\text { diagnóstico molecular } \\
\text { no mercado brasileiro. }\end{array}$ & & & $\begin{array}{c}\text { Pesquisa-ação 1: } \\
\text { Contexto/Proposta } \\
\text { Selecionar um método } \\
\text { estruturado para a } \\
\text { construção de modelo de } \\
\text { negócios em formato de } \\
\text { jornada. }\end{array}$ \\
\hline & $\begin{array}{c}\text { Aplicação de um } \\
\text { método para a } \\
\text { construção de modelo } \\
\text { de negócios para a } \\
\text { intervenção em uma } \\
\text { empresa startup de } \\
\text { biotecnologia de } \\
\text { diagnóstico molecular } \\
\text { no mercado brasileiro. }\end{array}$ & & & $\begin{array}{c}\text { Pesquisa-ação 2: } \\
\text { Ciclos Interativos } \\
\text { Planejamento, Ação, } \\
\text { Avaliação e Diagnóstico } \\
\text { do método em ciclos } \\
\text { planejados de acordo com } \\
\text { o método. }\end{array}$ \\
\hline
\end{tabular}

Figura 18. Matriz de amarração metodológica planejada (Fonte: A autora).

\subsection{Pesquisa de campo: Pesquisa-ação}

O intuito dessa fase da pesquisa é buscar pela metodologia da pesquisa-ação a compreensão, e análise, das fases consideradas no método de construção de modelo de negócios em uma empresa startup brasileira em biotecnologia.

A pesquisa-ação possui origem no trabalho de Kurt Lewin, colegas e associados em meados da década de 40 que conduziram projetos em diferentes configurações sociais. Nas décadas posteriores a pesquisa-ação em organizações foi ampliada no desenvolvimento de organizações (Coughlan \& Coghlan, 2002). A pesquisa-ação se tornou significante para pesquisa organizacional tal como organizações comerciais tal como definido por Shani \& Pasmore, 1985 em Coghlan \& Brannick, 2014.

"A pesquisa-ação pode ser definida como um processo de investigação emergente no qual o conhecimento da ciência comportamental aplicada é integrado ao conhecimento organização existente e aplicado para resolver problemas organizacionais reais. Isto é simultaneamente relativo à criação de mudança 
nas organizações, no desenvolvimento de competências de auto-ajuda em membros da organização e na adição ao conhecimento científico. Finalmente, é um processo em evolução que é realizado com um espírito de colaboração e co-inquérito (Shani \& Pasmore, 1985, pp.439)".

Pesquisa-ação é um termo genérico que atende muitas formas distintas de pesquisa orientada por ação, e indica diversidade na teoria e prática entre pesquisadores ação, de tal modo que proporciona ampla opção para potenciais pesquisadores ação quanto ao que pode ser apropriado para sua questão de pesquisa (Reason \& Bradbury, 2001 em Coughlan \& Coghlan, 2002). A pesquisa-ação é definida tradicionalmente como uma abordagem para pesquisa que é baseada em relação colaborativa para solução de problema entre o pesquisador e cliente que possui o objetivo de tanto resolver o problema quanto gerar novo conhecimento (Coghlan \& Brannick, 2014).

Os resultados são ambos a ação e a pesquisa focando no conhecimento em ação o que representa um contraste com a ciência positivista que por sua vez visa somente a criação de conhecimento. Ademais, podemos pontuar outros contrastes entre a pesquisa-ação e a ciência positivista, tal como: (i) o conhecimento criado pela pesquisa-ação é particular, situacional e fora de práxis, e não universal, (ii) os dados da pesquisa-ação são contextuais e interpretados, e não validados pela lógica e mensuração - no positivismo a consistência é alcançada pela predição e controle, (iii) a base para validação na pesquisa-ação é a consciência e promulgação deliberado, e não neutralidade e desapego, (iv) o pesquisador da pesquisa-ação é um ator e agente da mudança, e não um observador imparcial (Coughlan \& Coghlan, 2002).

Em geral, pesquisa-ação é apropriada quando a questão de pesquisa relaciona a descrição de uma série de desdobramentos de ações ao longo do tempo em um dado grupo, comunidade ou organização; compreendendo como um associado de um grupo, ou como e porque suas ações podem mudar ou aperfeiçoar o trabalho de alguns aspectos de um sistema (Coughlan \& Coghlan, 2002).

Notadamente, essa metodologia é uma abordagem que visa tanto a tomada de ação quanto a criação de conhecimento, ou teoria, sobre essa ação, que os autores Coughlan \& Coghlan, 2002 definem como provido das características: 
1. Pesquisa em ação ao invés de sobre a ação: A metodologia em questão utiliza uma abordagem científica para estudar a resolução de importantes questões sociais ou organizacionais junto com aqueles que possuem experiências com essas questões diretamente;

2. Possui 2 objetivos: resolve um problema e contribui para ciência. Não postula a distinção entre teoria e ação;

3. Participativa: associados do sistema que está sendo estudado participam ativamente no processo cíclico da metodologia, e não são objetos do estudo;

4. Interativa: cooperação entre os pesquisadores ação e associados clientes do sistema para resolução da questão, aperfeiçoamento do sistema e contribuição ao conhecimento; e contínuo ajuste a nova informação e novos eventos uma vez que pesquisa-ação é uma série de eventos imprevisíveis;

5. Concomitante com ação: tornar a ação mais efetiva enquanto simultaneamente desenvolve um corpo de conhecimento científico;

6. Visa o desenvolvimento de compreensão holística e reconhecimento de complexidade: as organizações são sistemas sócio-técnicos dinâmicos e o pesquisador deve se adaptar;

7. Fundamentalmente sobre mudança: é necessário ter conhecimento e habilidade na dinâmica da mudança organizacional.

8. Requer entendimento da estrutura ética: valores e normas em que são utilizados em contextos particulares na relação do pesquisador e membros do sistema;

9. Pode incluir todos os tipos de coleção de dados: ferramentas qualitativas e quantitativas são utilizadas e devem estar bem integradas no processo de pesquisaação.

10. Uma sequência de eventos e uma abordagem na solução de problema: como uma sequência de eventos que compreende ciclos interativos de coletar dados, alimentá-los de volta a aqueles de interesse, analisar os dados, planejar a ação, tomar a ação, e avaliar, conduzir a adicional coleta de dados e assim por diante. Como uma abordagem na solução de problemas essa metodologia é uma aplicação do método científico da descoberta do fato e experimentação para problemas práticos requerendo soluções de ação e envolvendo a colaboração e cooperação dos pesquisares ação e membros do sistema da organização. Os efeitos desejados da pesquisa-ação não são apenas soluções para os problemas imediatos, mas sim 
importantes aprendizados a partir dos resultados tanto intencionais como não intencionais, e uma contribuição ao conhecimento científico e à teoria.

11. É realizado em tempo real: o estudo é redigido enquanto se desenrola;

12. Requer seu próprio critério de qualidade: deve ser avaliado pelo critério de seus próprios termos e não dos critérios adotados pela ciência positivista

A pesquisa-ação utiliza uma abordagem científica para a resolução de importantes questões sociais e organizacionais juntamente com aqueles que experimentaram essas questões diretamente. Os membros do sistema que está sendo estudado participam ativamente nesse processo cíclico. O objetivo é tornar a ação mais eficaz ao mesmo tempo em que constrói um corpo de conhecimento científico.

A pesquisa-ação assim como qualquer outro método de pesquisa científica, deve ser pautada na confiabilidade e validade, características que mensuram sua qualidade ou rigor científico tal como definido por Mello et al., 2012. Os autores afirmam que a validação da pesquisa-ação dentro do paradigma científico do realismo os critérios mais adequados são: (i) adequação ontológica, ou seja, o mundo investigado é criação independente de mentes e criaturas; (ii) validade contingente que estabelece a validade mecanismos generativos e os contextos que o tornam contingentes; (iii) percepção múltipla dos participantes que demonstra como a pesquisa revela o mundo real; (iv) fidedignidade metodológica por meio do estabelecimento de um relatório que possa ser avaliado; (v) generalização analítica por meio do estabelecimento da primazia da construção da teoria no relatório; e (vi) validade do construto que determina quão bem os construtos na teoria que está sendo construída são mensuráveis pela pesquisa.

O processo de pesquisa-ação a ser adotado nesse trabalho é apresentado por Coghlan \& Brannick, 2014. O método de pesquisa-ação é definido por esses autores como uma abordagem para pesquisa que visa tanto a ação quanto a criação de conhecimento ou teoria referente à ação - e não somente a geração de conhecimento tal como obtida por meio das abordagens tradicionais de pesquisa.

Como uma sequencia de eventos, a pesquisa-ação para o contexto de sua própria organização opera por meio de um processo que inclui um ciclo principal concomitante, em paralelo com um ciclo de reflexão. 


\subsubsection{Ciclo principal}

O processo cíclico principal consiste da etapa de Contexto/Proposta (Pre-passo), seguida dos quatro passos básicos de: Diagnóstico (coleta de dados e provimento desses dados de volta aos interessados), Planejamento da ação (análise dos dados), Ação (implementação) e Avaliação da ação, levando a uma maior coleta de dados e assim por diante (Coghlan \& Brannick, 2014). A figura 19 ilustra o ciclo como mencionado.

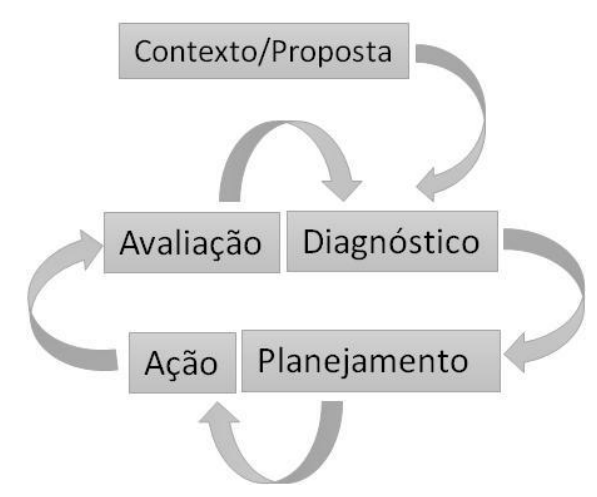

Figura 19. Ilustração do ciclo da pesquisa-ação (Fonte: adaptado de Coghlan \& Brannick, 2014).

A proposta nesse estudo foi definida como a utilização do método de construção de modelo de negócios descrito por Pedroso, 2018 para a concepção do modelo de negócios em uma empresa brasileira startup de biotecnologia no setor de diagnóstico molecular, a Sampa Tech.

A pesquisa-ação se desdobra em tempo real e inicia com o entendimento do contexto/proposta do projeto que compreende em definir: por que o projeto é desejável ou necessário, quais são as forças externas econômicas, políticas e sociais de mudança, quais são as forças internas culturais e estruturais de mudança, e como o sistema responde as forças de mudança. Uma vez definida a necessidade do projeto, há de se determinar o estado futuro desejado que determine os limites para a proposta do projeto.

O diagnóstico envolve a determinação do tema de trabalho em que a ação será planejada e implementada de forma que envolve a articulação das fundações teóricas da ação. 
Nota-se que o diagnóstico pode ser alterado nos ciclos posteriores da pesquisa-ação, e as mesmas devem ser gravadas e articuladas com clareza.

O planejamento da ação consiste em: análise do contexto/proposta do projeto e enquadramento da questão e diagnóstico. O processo é definido pelas fases: determinação da necessidade de mudança (o que, onde mudar), definição do estado futuro (tipo de mudança), acesso ao presente em termos do futuro para determinar o trabalho a ser realizado (como realizar a mudança), e gerenciamento da transição (recursos necessários, ex. suporte e stakeholders).

Vale notar que o enquadramento é um projeto é complexo, e o que parece claro pode ser alterado conforme o projeto se desenrola. O pesquisador deve fazer o enquadramento inicial, refletir se o enquadramento se encaixa ou não, articular entendimentos quanto ao porque esse enquadramento se encaixa ou não, implementar as ações adequadamente, e então testar e adaptar de acordo com os dados obtidos pelo enquadramento e seleção.

A implementação da ação ocorre de acordo com o planejamento, e as intervenções são realizadas. Há a implementação da ação planejada, por realização das mudanças almejadas e seguindo o planejamento de forma colaborativa.

A avaliação da ação envolve reflexão dos resultados da ação intencional e não intencional que são examinados pelos parâmetros: se o diagnóstico estava correto, se a ação foi implementada corretamente, se a ação ocorreu de forma apropriada, e o que alimenta o próximo ciclo de diagnóstico, planejamento e ação.

Em qualquer pesquisa-ação há múltiplos ciclos de pesquisa-ação operando concomitantemente, e envolve ciclos colaborativos entre pesquisador e cliente que de forma interativa se empenham para a identificação do problema, planejamento, ação e avaliação, tal como ilustrado na Figura 20. Tais ciclos promovem uma alteração na ação induzida pela reeducação dos participantes por meio da utilização dos dados coletados para revisar os fatos para o desenvolvimento da ação. 


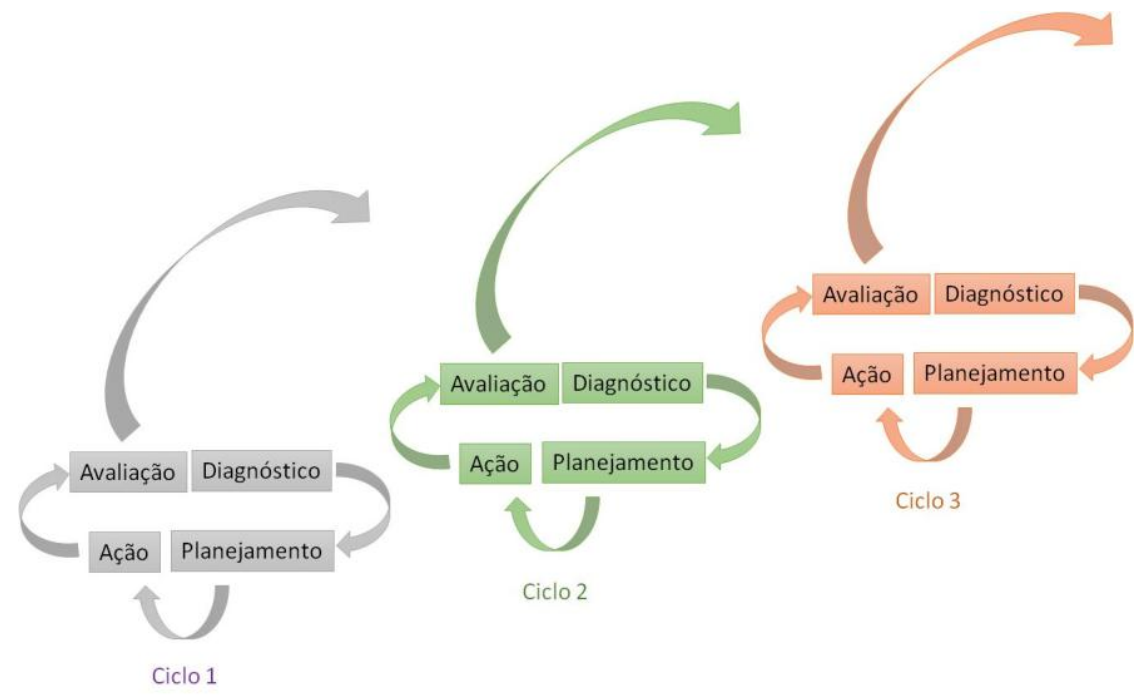

Figura 20. Ilustração dos ciclos interativos da pesquisa-ação (Fonte: adaptado de (Coghlan \& Brannick, 2014).

Vale ressaltar que como uma abordagem para a resolução de problemas, a pesquisaação é uma aplicação do método científico para encontro de fatos e experimentação para problemas práticos que exigem soluções de ação, e envolvem a colaboração e cooperação dos pesquisadores da ação e membros do sistema organizacional.

\subsubsection{Ciclo de reflexão}

O ciclo de reflexão consiste em ciclo de pesquisa-ação sobre o ciclo de pesquisa-ação. Ao mesmo tempo em que o pesquisador está engajado no estudo, ou ciclo principal de pesquisa-ação, o pesquisador necessita diagnosticar, planejar, implementar ação e avaliar sobre o andamento do projeto de pesquisa-ação per se, e o que está aprendendo. O pesquisador tenta aprender suas intenções para: desenvolver apropriados planos e estratégias, ter habilidades para cumpri-los, refletir em como cumpriu o planejamento, e para avaliar os resultados.

É a dinâmica dessa reflexão na reflexão que incorpora o processo de aprendizado do ciclo de pesquisa-ação e permite que a pesquisa-ação seja mais que uma solução corriqueira de problema. Consequentemente é aprendizado sobre aprendizado, ou seja, metaaprendizado. Assim, esse ciclo pode ser também denominado de meta-ciclo. 


\subsubsection{Pesquisador ação}

O pesquisador ação é um agente externo que age como facilitador da ação e reflexão dentro da organização (Coughlan \& Coghlan, 2002). Esse pesquisador possui o desafio de engajar em ambos os ciclos e fazer a ação acontecer, e se afastar da ação para refletir sobre como a mesma acontece de forma a contribuir para a teoria e o conhecimento. Além disso, o pesquisador precisa ter uma visão ampla de como o sistema funciona, ser capaz de se mover entre a estrutura formal e técnica para a informal, ter habilidade para trabalhar com complexidade dinâmica, conhecimento e habilidade na mudança do sistema organizacional, e possuir pré-conhecimento do ambiente da corporação, condições do negócio, estrutura e dinâmica dos sistemas de operação e sustentação teórica desses sistemas (Coughlan \& Coghlan, 2002).

Nesse estudo o pesquisador adaptou o método de acordo com o andamento da intervenção seguindo o processo de pesquisa-ação definido por Coghlan \& Brannick, 2014. Interessante notar que os autores apontam que o pesquisador ação em sua própria organização, também denominado de pesquisador ação confidente, pesquisa "em" e "sobre" sua própria organização enquanto é um associado completo, ou seja, é um associado da organização e pretende permanecer associado na carreira desejada quando a pesquisa for finalizada. Esse pesquisador deve ser capaz de combinar advocacia com inquérito de forma a não somente apresentar suas inferências, atribuições, opiniões e pontos de vista, mas também testar e criticar. Ainda, o pesquisador deve possuir experiência profissional e conhecimento no próprio sistema.

Nesse estudo, a pesquisadora da ação é uma associada do sistema organizacional, mais especificamente sócia fundadora da organização, e que preenche os requisitos de pesquisador ação como definido por Coghlan \& Brannick, 2014; Coughlan \& Coghlan, 2002.

\subsubsection{O estudo}

No presente estudo, o método de construção de modelos de negócios descrito por Pedroso, M.C., 2018 foi aplicado em uma empresa startup brasileira de biotecnologia para a verificação de sua aplicabilidade, êxito e limitações em empresa desse segmento, 
nacionalidade e porte. Nesse estudo, o universo da pesquisa, ou unidade de pesquisa, envolveu a intervenção na empresa brasileira de biotecnologia Sampa Tech.

A seleção da empresa Sampa Tech para esse estudo se relaciona diretamente às características peculiares de atuação, que permitem situá-la no escopo de investigação para compreensão do fenômeno de interesse enunciado pela questão de pesquisa. A empresa Sampa Tech é uma empresa startup de biotecnologia que iniciou suas atividades na área de diagnósticos moleculares em 2012. A empresa se dedica exclusivamente ao desenvolvimento de diagnósticos moleculares inovadores, e busca por um modelo de negócios sustentável e escalável.

O método seguiu ciclos de diagnóstico, planejamento, ação e avaliação tal como descrito nos itens 5.3.1.a, 5.3.1.b e 5.3.1.c.. O presente estudo consistiu de 3 ciclos planejados de pesquisa-ação que foram correspondentes as fases definidas no método de construção de modelo de negócios descrito em Pedroso, 2018, tal como descrito na Figura 21.

O ciclo 1 consistiu das ações definidas a partir do (I) Diagnóstico de Cenário: Descoberta (Insight) (1), Tamanho do mercado (2), Segmento de clientes (3) e Problema a ser resolvido (4).

O ciclo 2 consistiu das ações definidas a partir do (II) Diagnóstico de Validação do problema e Cenário: Tipo do modelo de negócios (6), Proposta de valor (7), Posicionamento competitivo (8), Modelo de geração de receita (9).

O ciclo 3 consistiu das ações definidas a partir do (III) Diagnóstico de Validação da solução e Cenário: Estrutura de custos (11), Fórmula de lucro (12), Modelo de operações (13), Modelo de relacionamento com clientes (14), Modelo de Inovação (15), Modelo de gestão (16), Estrutura de custos calculada (18) e Geração de valor (19).

A avaliação dos ciclos 1, 2 e 3 foram realizadas por meio de: Validação do problema (5), Validação da solução (10), e Validação do modelo de negócios (20), respectivamente. 


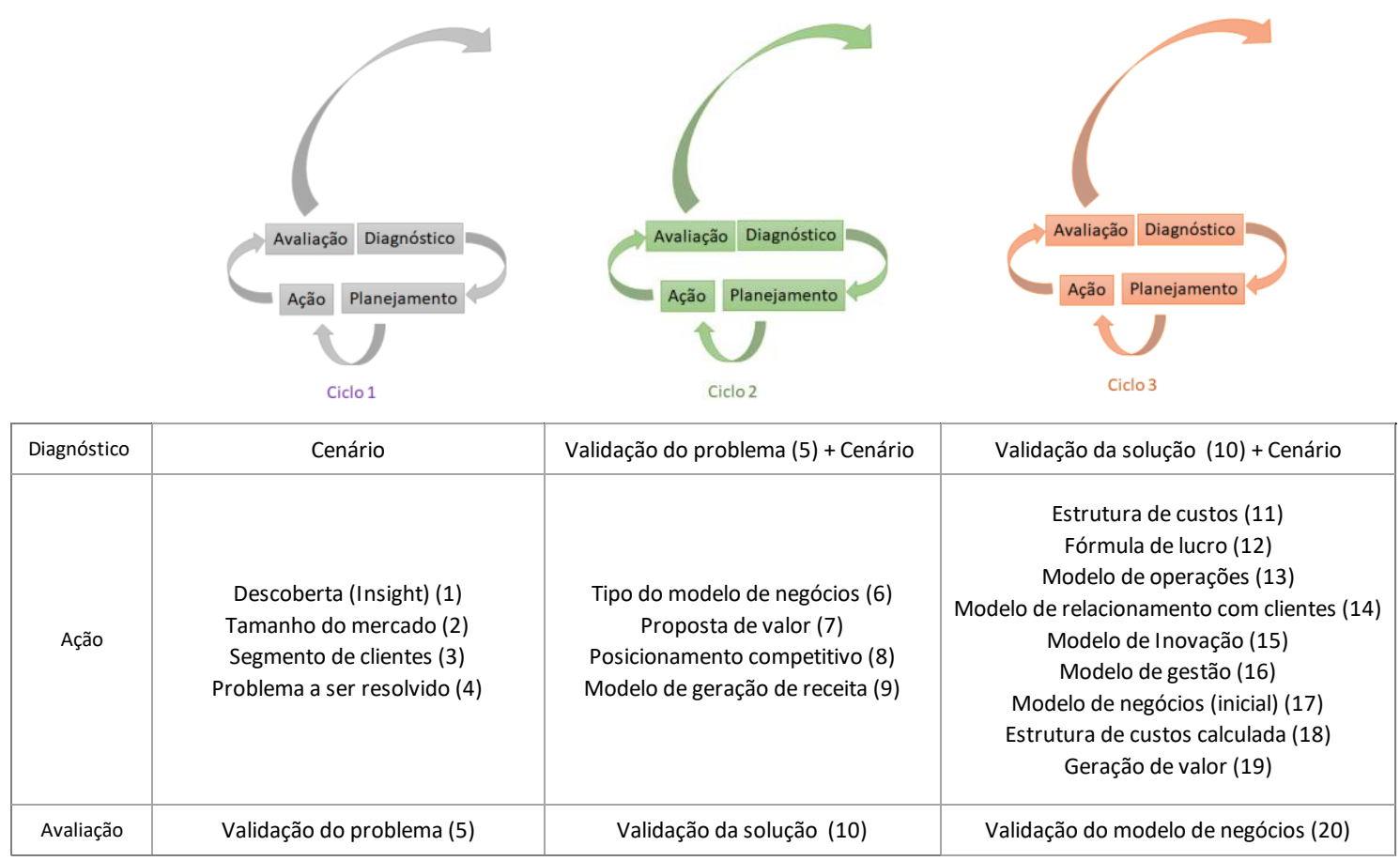

Figura 21. Ciclos 1, 2, 3 e 4 da pesquisa-ação do presente estudo correspondentes as fases definidas no método de construção de modelo de negócios descrito por Pedroso, 2018 (Fonte: A autora).

Os dados foram coletados no decorrer dos quatro ciclos, e particularmente no passo de avaliação a análise ocorreu por meio das planilhas pré-definidas no próprio método descrito por Pedroso, 2018. O resultado final do método de construção de modelo de negócios denominado de modelo de negócios (final) (21) corresponde ao resultado da avaliação do ciclo 4 da presente pesquisa-ação.

As reflexões da presente pesquisadora, os dados coletados e resultados intencionais e não intencionais da presente pesquisa-ação foram registrados em um diário de pesquisa no decorrer do estudo descrevendo ambos os ciclos principal e reflexivo da pesquisa-ação com foco no meta-ciclo. O diário de pesquisa auxiliou no meta-aprendizado da pesquisadora quanto ao conteúdo, processo e premissa na arena do preentendimento, ou seja, no que o pesquisador trouxe ao processo de pesquisa.

A geração de dados foi oriunda do envolvimento ativo no dia-a-dia da pesquisadora com os processos organizacionais relacionados ao estudo de pesquisa-ação. No presente estudo ambos a pesquisadora e o sistema estavam engajados com a participação ativa, e houve amplo comprometimento na experiência e aprendizado. O sistema estava comprometido com 
a mudança. O papel da pesquisadora envolveu ser parte da reflexão coletiva e aprendizado, e articulação dos acontecimentos.

Mais especificamente, a pesquisadora possui experiência prática em modelo de negócios nos ambientes acadêmico, corporativo e startup. Ainda, a pesquisadora atuou como mentora voluntária, e juíza, em eventos de promoção ao empreendedorismo em IDEs e geração de modelo de negócios a partir de tecnologias científicas ("hard science”) em programas realizados na Universidade Unicamp (Desafio Unicamp 2017) e Universidade de São Paulo (StartingUP Biotecnologia 2017, USP na Vatican Hack 2017 e Emerge Labs 2018). A pesquisadora participou em 2017 do Curso MIT's Entrepreneurship Bootcamp (Online): From Idea to Startup in Eight Weeks promovido pelo Massachusetts Institute of Technology (MIT) coordenado por Bill Aulet. Adicionalmente, a pesquisadora foi monitora das disciplinas Modelo de negócios: análise, conceito e inovação (EAP5021) e Laboratório de inovação do (EAP5026) ofertados pelo Mestrado Profissional em Empreendedorismo na FEA/USP. 


\section{RESULTADOS}

Nesse capítulo são descritos os resultados obtidos pela intervenção por meio da metodologia pesquisa-ação planejada e descrita no capítulo 5 para a geração de modelo de negócios em uma empresa startup do segmento de biotecnologia. O procedimento adotado nesse estudo para a geração de modelo de negócios é descrito por Pedroso, 2018. Os resultados são discutidos confrontando a prática com a teoria.

Os participantes da intervenção na Sampa Tech foram a pesquisadora (e concomitante co-fundadora da empresa) e o co-fundador da empresa. Os co-fundadores da empresa são também denominados de empreendedores da Sampa Tech.

A pesquisadora planejou a execução da pesquisa-ação em 3 ciclos que compreendem as 21 fases do procedimento de geração de modelo de negócios testado no presente estudo tal como ilustrado na Figura 22.

\begin{tabular}{|c|c|}
\hline \multicolumn{2}{|c|}{ CICLOS PLANEJADOS } \\
PESQUISA-AÇÃO \\
\hline CICLO 1 & ETAPAS 1 A 5 \\
\hline CICLO 2 & ETAPAS 6 A 10 \\
\hline CICLO 3 & ETAPAS 11 A 21 \\
\hline
\end{tabular}

Figura 22. Ciclos planejados da pesquisa-ação para a execução das etapas do procedimento de geração de modelo de negócios.

Durante a execução da pesquisa-ação, a pesquisadora se confrontou com a necessidade de interromper o ciclo 3 na etapa 12 e implementar um ciclo denominado de ciclo 4 , tal como ilustrado na Figura 23.

\begin{tabular}{|c|c|}
\hline \multicolumn{2}{|c|}{$\begin{array}{r}\text { CICLOS REALIZADOS } \\
\text { PESQUISA-AÇÃO }\end{array}$} \\
\hline CICLO 1 & ETAPAS 1 A 5 \\
\hline CICLO 2 & ETAPAS 6 A 10 \\
\hline CICLO 3 & ETAPAS 11 A 12 \\
\hline CICLO 4 & ETAPAS 3, 7, 9, 11 a 21 \\
\hline
\end{tabular}

Figura 23. Ciclos realizados da pesquisa-ação para o cumprimento das etapas do procedimento de geração de modelo de negócios. 


\subsection{Ciclo 1}

\subsubsection{Etapa $1 \quad$ Descoberta}

Nesse estudo, consideramos o procedimento descrito por Pedroso, 2018 que infere que a descoberta (ou insight) pode ocorrer especificamente pela identificação ou vivência de: problema, oportunidade, tecnologia (conhecimento), motivação pessoal (paixão) ou intuição.

Nesse procedimento é admitido que a descoberta segue o processo de identificação de oportunidades por meio da convergência das perspectivas do empreendedor que por sua vez estão inseridas no modelo de negócios e no panorama que o cerca. O panorama pode serdiscriminado como ecossistema e megatendências. Tal estrutura é descrita na Figura 24.

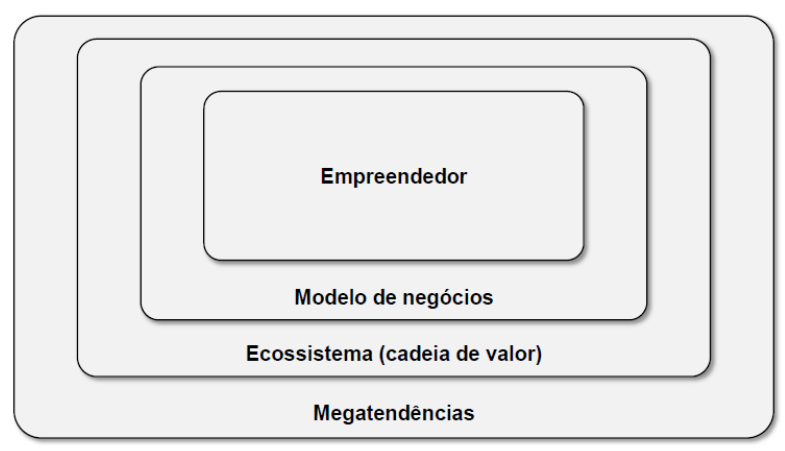

Figura 24. O processo de identificação de oportunidades engloba os parâmetros de megatendências, ecossistema (cadeia de valor), modelo de negócios e empreendedor (Fonte: Pedroso, 2018).

Assim, o procedimento descrito por Pedroso, 2018 sugere que na etapa 1 (descoberta) o usuário utilize as análises de:

- Componentes das competências do empreendedor. Esses componentes podem ser definidos como características e traços do empreendedor, tais como: conhecimento e experiência, motivação, capacidade e características pessoais (Driessen \& Zwart, 2007). 
- Ecossistema representado pela cadeia de valor do mercado-alvo. A cadeia de valor deve ser utilizada para determinação de pontos passíveis de serem explorados e que possam gerar oportunidades.

- As megatendências que podem ser enumeradas pela análise de: contexto externo (fatores políticos e regulatórios, econômicos, ecológicos, sócio-culturais, demográficos e tecnológicos) e tendências regulatórias, econômicas, ambientais, sociais/culturais, demográficas e tecnológicas. Essa análise pode ser estruturada por meio da representação de um quadro (canvas) de megatendências e análise do contexto externo.

A pesquisadora identificou que os empreendedores da Sampa Tech possuem como componentes de competências:

Capacidade e características pessoais: personalidade empreendedora que não se satisfaz na zona de conforto; possuem alta energia.

Conhecimento: possuem formação técnica afim do segmento que se pretende ter o empreendimento: área biológica e ciências da vida; possuem formação corporativa que agrega conhecimento no empreendimento, tai como Propriedade Intelectual (Patentes), Novos Negócios e Inovação;

Experiência: possuem experiência no segmento de biotecnologia, diagnóstico em alimentos e agricultura, farmacêutico, networking com diversos stakeholders do ecossistema de negócios, inovação, empresas privadas, institutos de pesquisa, universidades, agências de regulação (INPI, ANVISA) e propriedade intelectual.

Motivação: utilizar todo o conhecimento, potencial e anseio de cumprir as premissas para seu novo empreendimento tal como descrito abaixo.

Intuitivamente com fundamentação em suas competências, os fundadores definiram suas premissas para seu novo empreendimento:

1. Realizar inovação tecnológica em biotecnologia ou área afim;

2. Investir em Inovação distinta de biofármacos;

3. Cooperar na construção do ecossistema de empresas nascentes na área de biotecnologia no Brasil;

4. Atender o mercado global. 
No segundo momento, os fundadores buscaram a oportunidade de forma intuitiva por meio da análise das megatendências:

1. Tendências do mercado de biotecnologia com expectativa de alto crescimento nos próximos 5 anos; e

2. Mapeamento de tecnologia (literatura científica, patentes e mercado).

$\mathrm{Na}$ busca de tendências de mercado foi encontrado como promissor o mercado de diagnóstico molecular do tipo point-of-care (POC). As empresas farmacêuticas buscavam por inovação no modelo de negócios e encontraram a oportunidade dos companion kits (kits de acompanhamento) que se tornou uma grande promessa de novo mercado a se adequar e complementar ao modelo recente dos biofármacos e medicina personalizada.

Em seguida, por meio do mapeamento de tecnologia no mercado de POC, os empreendedores encontraram como oportunidade (insight) o desenvolvimento tecnológico de uma plataforma tecnológica inovadora na forma de biossensor de DNA a ser aplicado em POC. Essa oportunidade representa o desenvolvimento de um novo produto inovador disruptivo.

O insight da empresa startup foi assim definido como: produto point-of-care de DNA.

Um segundo objetivo dessa etapa é identificar o mercado-alvo referente a oportunidade. Dessa forma, a pesquisadora indica que após reflexão foi decidido pela Sampa Tech explorar como mercado de diagnóstico como um todo - por se tratar de uma tecnologia disruptiva que pode ser aplicada a distintos segmentos industriais simultaneamente. A pesquisadora esclarece que não houve a necessidade da análise do ecossistema de forma extensiva e formal por meio do canvas de megatendências e contexto externo.

Além disso, a pesquisadora elucida que os parâmetros perspectivas do empreendedor e megatendências foram suficientes para a definição da oportunidade, não sendo necessária a análise extensiva da cadeia de valor.

A pesquisadora aponta que no decorrer do processo, houve contribuição do conhecimento tácito dos empreendedores sobre a cadeia de valor em alguns setores da do segmento da biotecnologia. Note que a cadeia de valor de biotecnologia mais difundida é a de 
biofármacos que não se aplica à oportunidade selecionada pelos dos empreendedores. Não há uma cadeia de valor única para biotecnologia. A mesma é dependente do tipo de produto, tecnologia e segmento da indústria ao que se aplica. Por essa razão possivelmente a análise do ecossistema não foi necessária - não era aplicável.

O resultado do processo juntamente com a reflexão da pesquisadora no decorrer do processo é resumido na Figura 25.

\begin{tabular}{|c|c|c|c|}
\hline PROCESSO & QUESTÃo & RESPOSTA AO PROCESSO & REFLEXÃo DA PESQUISADORA \\
\hline IDENTIFICAÇÃO & Oportunidades identificadas foram identificadas? & SIM & $\begin{array}{l}\text { Foi realizada por meio das competências dos } \\
\text { empreendores e megatendências. No caso } \\
\text { da Sampa Tech não foi necessário definir o } \\
\text { contexto externo como sugerido pelo } \\
\text { processo. Todavia, foi realizado o } \\
\text { mapeamento de tecnologia, ou seja, } \\
\text { mapeamento das tecnologias existentes no } \\
\text { mercado e documentos de patente. Esse } \\
\text { método foi relevante e parece ser aplicável } \\
\text { de forma eficiente a novas tecnologias. }\end{array}$ \\
\hline ESCOLHA & A oportunidade foi selecionada? & SIM & $\begin{array}{l}\text { Foi uma consequência direta das conclusões } \\
\text { do processo descrito acima. }\end{array}$ \\
\hline \multirow{3}{*}{ ANÁLISE } & O mercado-alvo foi definido? & SIM & $\begin{array}{l}0 \text { mercado-alvo foi definido de uma forma } \\
\text { genérica: como diagnóstico Point-of-care. }\end{array}$ \\
\hline & A cadeia de valor foi desenhada? & NÃO & \multirow{2}{*}{$\begin{array}{l}\text { Não há uma cadeia de valor única para } \\
\text { biotecnologia. A mesma é dependente do } \\
\text { tipo deproduto, tecnologia e segmento a } \\
\text { que se aplica. Por essa razão a análise do } \\
\text { ecossistema não foi necessária - não era } \\
\text { aplicável. }\end{array}$} \\
\hline & $\begin{array}{l}\text { Há pontos na cadeia de valor para ser explorado para a } \\
\text { oportunidade? }\end{array}$ & NÃO FOI EXPLORADO & \\
\hline
\end{tabular}

Figura 25. Quadro ilustrativo que resume os resultados da etapa 1 do ciclo 1 (Fonte: adaptado de Pedroso, 2018).

\subsubsection{Etapa $2 \quad$ Tamanho de mercado}

O objetivo da etapa 2 do processo descrito por Pedroso, 2018 é definir o mercado em 4 níveis. Para essa definição devem-se assumir premissas que servem de embasamento para o cálculo do mercado nos níveis particulares que justifiquem o seu alcance por meio do insight selecionado.

Nesse estudo as métricas de tamanho de mercado são representadas por:

(i) Mercado potencial (potencial acessible market, PAM) que refere-se a estimativa do mercado endereçável acrescido do mercado que demanda produtos e serviços substitutos e complementares;

(ii) Mercado endereçável (total addressable market, TAM) que refere-se a estimativa do mercado que demanda o produto ou serviço; 
(iii) Mercado disponível (served available market, SAM) que refere-se a estimativa do mercado-alvo; e

(iv) Mercado realista (serviceable \& obtainable market, SOM) que refere-se a estimativa realista do mercado a ser obtido.

Os números de mercado foram pesquisados na literatura técnica e de mercado, analisados e definidos nas métricas de tamanho de mercado tal como ilustrado na Figura 26. Por conseguinte, a pesquisadora considerou como premissas para o mercado da Sampa Tech:

- O mercado potencial (PAM) é o mercado de diagnóstico in vitro (In-Vitro Diagnostics, IVD) que é definido por compreender dispositivos médicos e acessórios que auxiliam na detecção de amostras coletadas do corpo humano de forma a diagnosticar uma condição médica particular, monitorar terapia por drogas, e prevenir doença. Aparatos de IVD e produtos associados incluem reagents, kits, software, calibradores, and materiais de controle. A agência americana de vigilância sanitaria The U.S. Food \& Drug Administration (FDA) define IVD como aqueles "reagentes, instrumentos e sistemas intended para diagnosticar doenças ou outras condições".

A estimativa desse mercado é de USD \$ 87,3 bilhões em 2024.

- O mercado endereçável (TAM) refere-se aos mercados de diagnóstico molecular e point-of-care, mais particularmente na interseção entre os mesmos.

Diagnóstico molecular é definido como uma técnica usada para detectar a presença e identificar materiais genéticos e proteínas associados a condições de saúde e doenças específicas, e agentes infecciosos em fluidos corporais, como sangue, urina ou expectoração. As tecnologias de diagnóstico molecular são usadas principalmente para diagnosticar doenças infecciosas (ex. HIV, tuberculose), triagem de sangue, teste oncológico com tecnologias do tipo PCR, hibridização in situ, chips e microarrays, espectrometria de massa e amplificação isotérmica. O diagnóstico molecular para testes de doenças infecciosas é usado por hospitais, instituições acadêmicas, laboratórios e outros. $\mathrm{O}$ aumento do número de doenças infecciosas e o avanço tecnológico em tecnologias de diagnóstico de doenças infecciosas são alguns dos principais fatores que impulsionam o diagnóstico molecular no mercado de testes de doenças infecciosas.

A estimativa desse mercado é de USD \$ 12,5 bilhões em 2024. 
O mercado point-of-care consideram testes diagnósticos remotos e rápidos (ex. glicose, lipídeos, hemoglobina glicada, hepatite C, HIV, influenza, urinálise, hematologia, câncer, gravidez, tempo de coagulação/protrombina), na plataforma de fluxo lateral ou imunoensaio, sob modo de prescrição ou OTC (over the counter).

A estimativa desse mercado é de USD \$ 38,13 bilhões em 2022, e CAGR (compound annual growth rate) de $10 \%$.

- O mercado disponível (SAM) é o mercado de diagnóstico point-of-care molecular que é definido por produto e serviço amplamente segmentado em testes e kits, instrumentos / analisadores, software e serviços. Espera-se que o segmento de kits seja projetado ter o no período de previsão. Um número crescente de ensaios e kits nesse mercado recebeu o status de isenção da CLIA, que define que o produto pode ser usado para ambientes descentralizados ou laboratórios não tradicionais, incluindo consultórios médicos, salas de emergência e clínicas de departamentos de saúde. Com base na tecnologia, o mercado é amplamente segmentado em RT-PCR, INAAT e outras tecnologias. Espera-se que o segmento RT-PCR seja responsável pela maior parte do mercado. A RT-PCR é uma tecnologia altamente econômica e preferencial para configurações de POC que permite o monitoramento simultâneo de níveis de expressão de múltiplos genes. Tais benefícios estão impulsionando o crescimento do segmento RT PCR. Com base de aplicação, o mercado é amplamente segmentado em doenças respiratórias, infecções hospitalares (IACS), doenças sexualmente transmissíveis (DSTs), oncologia, hepatite e outras aplicações (meningite meningocócica, malária, vírus herpes simplex, Ebola, Zika vírus ). Com base nos usuários finais, o mercado é amplamente segmentado em consultórios médicos, hospitais e unidades de terapia intensiva, institutos de pesquisa e outros usuários finais. Espera-se que o segmento de consultórios médicos detenha a maior fatia do mercado.

A estimativa desse mercado é de USD \$ 1,4 bilhões em 2023.

- O mercado realista (SOM) é o mercado estimado de diagnóstico point-of-care de DNA. O SOM foi definido com a premissa de que o diagnóstico point-of-care de DNA alcançará $20 \%$ do mercado global de point-of-care.

A estimativa desse mercado é de USD \$ 280 milhões em 2023.

Interessante notar que a pesquisadora assumiu o mercado de diagnóstico no segmento médico como estimativa para as métricas de tamanho de mercado da startup analisada, 
embora tenha o conhecimento de que o mercado do produto da Sampa Tech é mais abrangente. A razão está na impossibilidade de obtenção de números claros e precisos referentes aos mercados novos para diagnóstico point-of-care que a Sampa Tech pretende explorar (ex. entretenimento). A pesquisadora esclarece que para métricas mais precisas e realistas necessitaria de relatórios de mercado disponíveis na literatura que forneçam dados de mercado de diagnóstico em todos os segmentos da indústria (ex. alimentos, agropecuária), e/ou informações confidenciais das empresas desses segmentos - o que não foi encontrado.

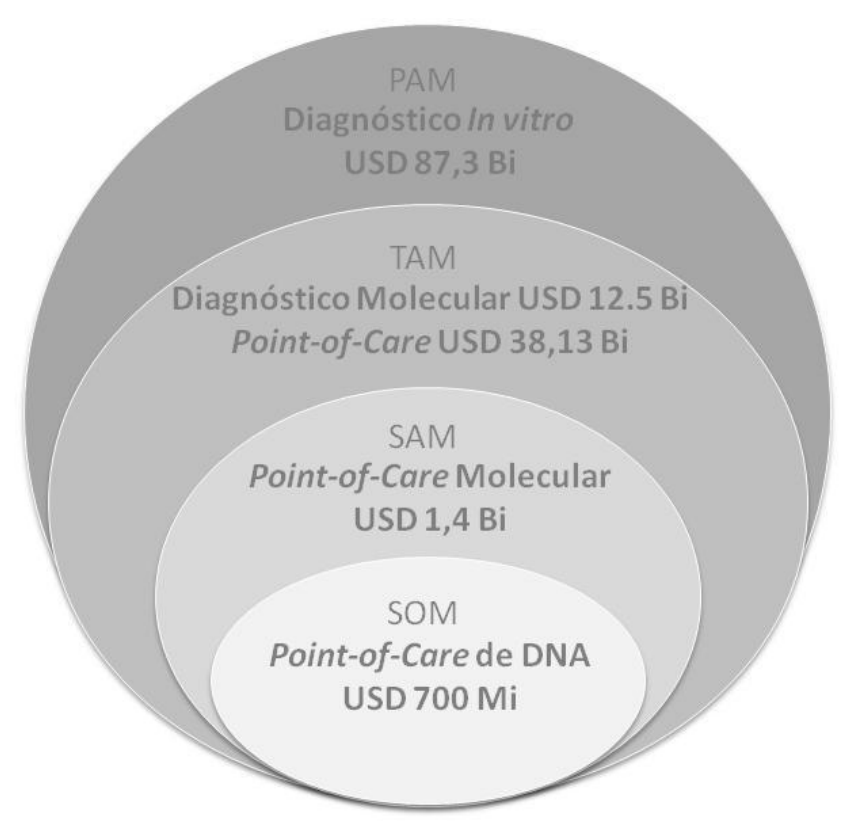

Figura 26. Tamanho de mercado alvo da startup Sampa Tech (Fonte: adaptado de Pedroso, 2018).

O resultado do processo juntamente com a reflexão da pesquisadora no decorrer da etapa 2 do processo é resumido na Figura 27. 


\begin{tabular}{|c|c|c|c|}
\hline PROCESSO & QUESTÃo & RESPOSTA AO PROCESSO & REFLEXÃO DA PESQUISADORA \\
\hline \multirow{3}{*}{ TAMANHO DO MERCADO-ALVO } & Qual o tamanho do mercado? TAM & USD $\$ 50,63 \mathrm{Bi}$ & \multirow{3}{*}{$\begin{array}{l}\text { O cálculo do tamanho de mercado em } 4 \\
\text { níveis foi apropriado e eficiente no processo } \\
\text { como balizador da existência de mercado } \\
\text { atrativo para o produto. Seria interessante } \\
\text { adicionar ao processo a questão inicial "se o } \\
\text { mercado é global ou territorial" para } \\
\text { reflexão da startup. }\end{array}$} \\
\hline & Qual o tamanho do mercado? SAM & USD $\$ 1,4 \mathrm{Bi}$ & \\
\hline & Qual o tamanho do mercado? SOM & USD $\$ 700 \mathrm{Mi}$ & \\
\hline
\end{tabular}

Figura 27. Quadro ilustrativo que resume os resultados da etapa 2 do ciclo 1. (Fonte: adaptado de Pedroso, 2018.

\subsubsection{Segmento de clientes}

O processo percorrido nesse estudo sugere a segmentação de clientes em mercados consumidores (B2C) ou mercados organizacionais (B2B) tal como descrito por Pedroso, 2018.

A segmentação dos mercados consumidores (B2C) ocorre por definição geográfica (região, porte da cidade, densidade, área), demográfica (idade, tamanho da família, ciclo de vida da família, gênero, renda, ocupação, grau de instrução, religião, raça, geração, nacionalidade, classe social), psicográfica (estilo de vida e personalidade), ou comportamental (ocasiões, benefícios, status do usuário, índice de utilização, status de fidelidade, estágio de prontidão, atitude em relação ao produto).

A segmentação dos mercados organizacionais (B2B) ocorre por definição demográfica (setor, porte da empresa, localização), operacional (tecnologia, status de usuários e não usuários, recursos dos clientes), abordagem de compra (organização em relação a compras, estrutura de poder, natureza dos relacionamentos existentes, políticas gerais de compras, critérios de compra), fatores situacionais (urgência, aplicação específica, tamanho do pedido), características pessoais (similaridade comprador/vendedor, atitudes em relação ao risco, fidelidade).

Interessante notar que o produto diagnóstico point-of-care de DNA desenvolvido pela Sampa Tech por meio de plataforma tecnológica proprietária é inovador e disruptivo que visa atender novos mercados. O teste será aplicado para determinação de ausência ou presença de determinada característica, organismo (ex. vírus, bactéria), espécie (ex. porco, cavalo), mutação, clones, entre outros - por detecção de variantes genéticas (ou marcadores genéticos) particulares. Por essas características os fundadores definiram que esse produto deve atender consumidores a nível global que possuem essa necessidade. O mercado a ser atendido inclui 
diversos segmentos industriais tais como saúde, agropecuária, entretenimento, entre outros. Os clientes e usuários finais seriam pertencentes aos mercados consumidores (B2C) e mercados organizacionais (B2B).

A pesquisadora e fundador da Sampa Tech definiram que o mercado B2C que atenderia ao mercado segmentado por definição geográfica (Global, mas inicialmente cidades de São Paulo e Rio de Janeiro), demográfica (Médico), psicográfica (Viaja com frequência para reciclagem, susceptível a novas tecnologias e produtos), ou comportamental (Atualizado, visualiza necessidade de diagnóstico preciso e rápido aos pacientes com tecnologia de ponta). Além disso, eles vislumbraram que o protótipo que estava sendo concebido atenderia ao mercado B2C segmentado também por definição geográfica (Brasil, Capitais), demográfica (jovem de 16 a 35 anos de idade com escolaridade de pelo menos fundamental) e comportamental (antenado em novas tendências e inovação).

Com relação à segmentação dos mercados organizacionais (B2B), a pesquisadora definiu as características definição demográfica (multisetorial, grande porte, global), operacional (que utiliza, ou possa utilizar, teste diagnóstico molecular), abordagem de compra (que possua pré-disposição a parceria de co-desenvolvimento), fatores situacionais (para aplicação específica), características pessoais (que possua equipe de inovação e/ou técnica que compreenda os benefícios do produto).

O resultado do processo juntamente com a reflexão da pesquisadora no decorrer do da etapa 3 do processo é resumido na Figura 28. 


\begin{tabular}{|c|c|c|c|}
\hline PROCESSO & QUESTÃO & RESPOSTA AO PROCESSO & REFLEXÃO DA PESQUISADORA \\
\hline SEGMENTO DE CLIENTES & Quais são os segmentos alvo de clientes? & $B 2 C, B 2 B$ & \\
\hline PERFIL DOS CLIENTES & Qual é o perfil dos clientes desse(s) segmento(s)? & $\begin{array}{l}\text { B2C: (Saúde) Médico que viaja com frequência para } \\
\text { reciclagem, susceptível a novas tecnologias e } \\
\text { produtos. Profissional atualizado que prevê a } \\
\text { necessidade de diagnóstico preciso e rápido. } \\
\text { (Entretenimento) Jovem de } 16 \text { a } 35 \text { anos de idade } \\
\text { com alta escolaridade antenado em novas } \\
\text { tendências e inovação. } \\
\text { B2C: Multisetorial e global. Empresas de grande } \\
\text { porte que utiliza, ou possa utilizar, teste } \\
\text { diagnóstico moleculare que possua pré-disposição } \\
\text { a parceria de co-desenvolvimento para aplicação } \\
\text { específica, e que possua equipe de inovação e/ou } \\
\text { técnica que compreenda os benefícios do produto. }\end{array}$ & $\begin{array}{l}\text { Houve dificuldade na reflexão sobre } \\
\text { segmento de cliente anteriormente a } \\
\text { solução (resolução do problema) e } \\
\text { posicionamento competitivo. Talvez porque } \\
\text { a oportunidade da Sampa Tech é por si uma } \\
\text { solução o que muda a ordem do processo, } \\
\text { seguindo a lógica technology push com foco } \\
\text { na solução. Ou ainda pelo conhecimento } \\
\text { intrínseco nos clientes pelos fundadores. } \\
\text { Vale ressaltar que inicialmente, por meio de } \\
\text { vivência no curso do MIT que fundamenta-se } \\
\text { no processo descrito por Aulet, } 2013 \text { achava } \\
\text { difícil pensar na oportunidade sem pensar } \\
\text { no mercado concomitantementer No } \\
\text { processo atual não senti essa dificuldade, } \\
\text { provavelmente por causa do desenho de } \\
\text { macrotendências onde pode-se encaixar essa } \\
\text { característica. }\end{array}$ \\
\hline
\end{tabular}

Figura 28. Quadro ilustrativo que resume os resultados da etapa 3 do ciclo 1 (Fonte: adaptado de Pedroso, 2018.

\subsubsection{Etapa $4 \quad$ Problema a ser resolvido}

O processo proposto por Pedroso, 2018 propõe que a definição do problema a ser resolvido (job to be done) pela startup deva ser centrada na enumeração dos problemas importantes, ou necessidades, que devem ser atendidos para os clientes, ou seja, em quais circunstâncias ou ocasiões esses problemas ou necessidades ocorrem - tendo em vista que os clientes contratam soluções para resolver problemas importantes para atender suas necessidades.

A compreensão do ciclo de experiência dos clientes pode ser de grande auxílio para a definição dos problemas a serem atendidos do ponto de vista funcional, de conveniência, intangível ou preço. Além disso, as informações sobre os problemas do cliente podem ser adquiridas por observação etnográfica, entrevistas, focus group ou pesquisas quantitativas. O processo utilizado nesse estudo sugere a utilização da matriz de importância-desempenho como ferramenta para essa análise.

Entretanto, a pesquisadora não utilizou dessa ferramenta uma vez que a oportunidade da Sampa Tech corresponde a uma solução já estabelecida como parte do avanço tecnológico e consequência de conhecimento e inovação em biologia molecular projetada pelos cofundadores. A pesquisadora entende que a matriz de importância-desempenho não agrega informações relevantes para a definição do problema. 
Os benefícios de um produto ou serviço percebidos pelo usuário e/ou cliente podem ser definidos pela denominação atributos competitivos de acordo com as dimensões dos problemas a serem resolvidos (Pedroso, 2017). Esses atributos podem as ser classificados como:

- Atributo preço é definido por QUANTO a empresa cobra para entregar os benefícios por meio dos produtos e serviços.

- Atributo funcional inclui O QUE É entregue por meio dos produtos ou serviços.

- Atributo de conveniência consiste em COMO os produtos ou serviços são entregues.

- Atributo intangível é definido por QUAL é a percepção sobre a entrega dos produtos ou serviços.

Diagnóstico molecular é um termo utilizado para descrever uma família de técnicas para analisar marcadores biológicos no código genético de um indivíduo (genoma) e analisar como suas células expressam seus genes como proteínas (proteoma) (Turner \& Tsongalis, 2016).

Consideramos nesse estudo que testes diagnósticos moleculares são necessários e utilizados no segmento industrial de: saúde como sendo parte integral ou complementar do diagnóstico, tratamento e prognóstico de pacientes, agropecuária como sendo parte da identificação de clones específicos de organismos modificados geneticamente ou cultivares, identificação de indivíduos contendo traços associados a alta performance, alimentos como sendo parte da identificação de organismos modificados geneticamente e componentes alergênicos, e outros.

Atualmente existem no mercado testes diagnósticos moleculares do tipo: (i) laboratório que são realizados por meio de reagentes e kits que requerem equipamentos específicos e complexos para sua operação, e (ii) point-of-care (POC) que são testes remotos em forma de kit compacto que não requerem equipamento para sua operação.

No caso de testes diagnósticos moleculares do tipo laboratório a amostra a ser analisada é coletada no próprio laboratório em que será processado, ou de forma remota em que a amostra é enviada ao laboratório. A amostra é coletada por técnico qualificado (ex. hospital, clínica, laboratório clínico, fazenda, fábrica, loja) ou pelo próprio indivíduo (ex. empresa 23andme). O resultado, ou laudo, é enviado para o requerente após processamento 
que pode durar entre um dia a alguns meses. Os testes moleculares genéticos (PCR, sequenciamento, micro array) requerem equipamentos complexos e somente podem ser realizados em laboratório. Entretanto, atualmente, existem algumas iniciativas de startups que estão lentamente viabilizando equipamentos de PCR miniaturizados.

Entretanto, para testes diagnósticos moleculares do tipo POC a amostra a ser analisada é coletada no próprio local em que será processada, sendo que o resultado, ou laudo, é rápido (até 1 hora) dispensando o uso de equipamento em face do resultado colorimétrico visível a olho nu, e a simplicidade intrínseca do produto. A amostra é coletada pelo próprio indivíduo (ex. teste de gravidez, HIV, Influenza A e B). Interessante notar que os testes moleculares POC existentes no mercado possuem fundamentação na detecção de proteína.

Observa-se um problema a ser resolvido no setor de diagnósticos moleculares que é a ausência de testes diagnóstico molecular do tipo POC para analisar o código genético. A Sampa Tech definiu um produto oriundo de um avanço tecnológico que resolve especificamente esse problema. Nota-se que o problema foi definido pela solução que já havia sido previamente desenhada.

O produto da Sampa Tech pode ser aplicado para determinação de ausência ou presença de determinada característica, organismo (vírus, bactéria), espécie (porco, cavalo), mutação, clones, entre outros - por variantes genéticas. O mesmo confere especificidade, precisão e rapidez em laudo obtido no sítio (on site) da coleta da amostra (atributos do produto). Por essas características a pesquisadora e co-fundador definiram que o teste deveria atender clientes que possuem essa necessidade.

Os atributos competitivos do produto da Sampa Tech são:

- atributos funcionais de desempenho e facilidade de uso: permite resposta precisa a perguntas antes respondidas somente em laboratório, com necessidade de equipamento (ex. PCR) e operador técnico qualificado. Geralmente, a logística prevê o envio da amostra para laboratório centralizado, ou coleta da amostra no próprio laboratório, demora na emissão do laudo de resultado (semanas a meses). No caso da solução da Sampa Tech a coleta da amostra e laudo preciso ocorrem concomitantemente no mesmo local por ser remoto (on site), é rápido, dispensa a necessidade de equipamento, e de operador qualificado;

- atributo de conveniência: o produto da Sampa Tech é uma plataforma que permite o desenvolvimento de uma ampla gama de produtos distintos, ou seja, uma linha de produtos. 
Assim, a linha de produtos assume uma variedade de opções de produto e de flexibilidade de customização

- atributo intangível: o produto da Sampa Tech promove a inclusão dos clientes do mercado B2B a um grupo e status no segmento de entretenimento e saúde.

Dessa forma, a pesquisadora conclui que o produto da Sampa Tech atende ao mercado almejado. O mesmo forneceria uma solução a problemas existentes no mercado de diagnóstico molecular.

O resultado do processo juntamente com a reflexão da pesquisadora no decorrer do da etapa 4 do processo é resumido na Figura 29.

\begin{tabular}{|c|c|c|c|}
\hline PROCESSO & QUESTÃo & RESPOSTA AO PROCESSO & REFLEXÃO DA PESQUISADORA \\
\hline EXPERIÊNCIA DOS CLIENTES & $\begin{array}{c}\text { Quais são as principais etapas (ou atividades) associadas à } \\
\text { experiência dos clientes? }\end{array}$ & Não foi realizado. & $\begin{array}{l}\text { A pesquisadora concluiu que a matriz de } \\
\text { importância-desempenho não agregaria } \\
\text { informações relevantes para a definição do } \\
\text { problema, e assim não a utilizou. Contudo, a } \\
\text { enumeração dos atributos competitivos foi } \\
\text { bastante relevante nesse processo. }\end{array}$ \\
\hline $\begin{array}{l}\text { IDENTIFICAÇ̃̃O DOS PROBLEMAS A } \\
\text { SEREM RESOLVIDOS }\end{array}$ & Quais os problemas a serem resolvidos? & $\begin{array}{l}\text { O fato de ser mandatório o diagnóstico molecular } \\
\text { preciso ser realizado em laboratório com } \\
\text { necessidade de uso de equipamento e operador } \\
\text { qualificado, em processo que prevê o envio de } \\
\text { amostra e resultado demorado. }\end{array}$ & $\begin{array}{l}\text { Uma vez que a oportunidade é uma solução, } \\
\text { o problema foi buscado previamente e } \\
\text { intrisecamente com a definição dos } \\
\text { atributos competitivos do produto. }\end{array}$ \\
\hline $\begin{array}{l}\text { ESCOLHA DOS PROBLEMAS A SEREM } \\
\text { RESOLVIDOS }\end{array}$ & Quais problemas a serem resolvidos foram selecionados? & $\begin{array}{l}\text { Todos os problemas acima visto que o produto é } \\
\text { uma solução para todos os pontos apontados. }\end{array}$ & \\
\hline
\end{tabular}

Figura 29. Quadro ilustrativo que resume os resultados da etapa 4 do ciclo 1. (Fonte: adaptado de Pedroso, 2018).

\subsubsection{Etapa $5 \quad$ Validação do problema}

A pesquisadora e o co-fundador da Sampa Tech validaram o problema por meio de revisão da literatura técnica, e por entrevistas com stakeholders de empresas de grande porte do setor de diagnóstico clínico e agronegócio e com investidores.

O resultado do processo juntamente com a reflexão da pesquisadora no decorrer do da etapa 5 do processo é resumido na Figura 30. 


\begin{tabular}{|c|c|c|c|}
\hline PROCESSO & QUESTÃo & RESPOSTA AO PROCESSO & REFLEXÃO DA PESQUISADORA \\
\hline \multirow{4}{*}{$\begin{array}{l}\text { VALIDAÇ̄̃O DOS PROBLEMAS A } \\
\text { SEREM RESOLVIDOS }\end{array}$} & Quais foram os elementos (ex.: problemas) testados? & $\begin{array}{l}\text { O fato de ser mandatório o diagnóstico molecular } \\
\text { preciso ser realizado em laboratório com } \\
\text { necessidade de uso de equipamento e operador } \\
\text { qualificado, em processo que prevê o envio de } \\
\text { amostra e resultado demorado. }\end{array}$ & \multirow{4}{*}{$\begin{array}{l}\text { Não foi encontrado elemento relevante } \\
\text { adicional para ser discutido. }\end{array}$} \\
\hline & Quais foram os métodos de validação? & $\begin{array}{l}\text { Revisão da literatura técnica, e entrevistas com } \\
\text { stakeholders de empresas de grande porte do setor } \\
\text { de diagnóstico clínico e agronegócio e com } \\
\text { investidores. }\end{array}$ & \\
\hline & Quais elementos foram validados? & Todos os elementos foram validados. & \\
\hline & Quais evidências demonstram as validações? & $\begin{array}{l}\mathrm{O} \text { interesse em realizar co-desenvolvimento e } \\
\text { compra do produto. }\end{array}$ & \\
\hline
\end{tabular}

Figura 30. Quadro ilustrativo que resume os resultados da etapa 5 do ciclo 1. (Fonte: adaptado de Pedroso, 2018).

\subsection{Ciclo 2}

\subsubsection{Etapa $6 \quad$ Tipo do Modelo de Negócios}

Nesse estudo foi utilizada a tipologia de modelos de negócios de acordo com a definição de Pedroso, 2018 que estabelece que há tipos de modelos de negócios relacionado a entrega de produtos (produtos), serviços (serviços) ou conexões (plataforma), sendo que a interseção entre esses tipos originam outros tipos tais como mercado de produtos (entre plataforma e produtos), mercado de serviços (entre plataforma e serviços), servitização, ou produto como serviço (entre produtos e serviços) e ecossistema (entre plataforma, produtos e serviços).

Ainda, os tipos de modelos de negócios acima listados consistem dos submodelos: (i) produtos - manufatura, varejo e distribuição, comércio eletrônico, (ii) serviços - intensivos em produto, intensivos em pessoas, intensivos em informação, e (iii) plataforma - comunidades (redes sociais), mercados multilaterais e ecossistemas, tal como ilustrado na Figura 31.

\begin{tabular}{|c|c|c|c|}
\hline \multicolumn{2}{|c|}{ TIPOLOGIA DE MODELO DE NEGÓCIOS } & SUBMODELO & MODELO DESCRITO POR GASSMANN, 2014 \\
\hline \multirow{3}{*}{ PRODUTO } & MANUFATURA & Manufatura & \\
\cline { 2 - 4 } & DISTRIBUIÇÃO E VAREJO & Distribuição e varejo & \#13 eCommerce \\
\cline { 2 - 4 } & COMÉRCIO ELETRÕNICO & Comércio eletrônico & \\
\hline \multirow{3}{*}{ SERVIÇO } & PRODUTOS & Serviços intensivos em produtos & \#37 peer-to-peer \\
\cline { 2 - 4 } & PESSOAS & Serviços intensivos em pessoas & \#52 two sided market \\
\cline { 2 - 4 } & INFORMAÇÃO & Serviços intensivos em informação & \\
\hline \multirow{2}{*}{ PLATAFORMA } & REDES SOCIAIS & Redes sociais & Mercado multilateral \\
\cline { 2 - 4 } & MERCADOS MULTILATERAI & Ecossistema & \\
\cline { 2 - 4 } & ECOSSISTEMA & &
\end{tabular}

Figura 31. Tipologia e Submodelo de Modelo de Negócios. (Fonte: adaptado de Pedroso, 2018). 
A pesquisadora e o co-fundador da Sampa Tech definiram a tipologia do modelo de negócios da startup como sendo produto e o submodelo manufatura. A premissa era desnvolver a tecnologia da Sampa Tech, desenvolver novos produtos inovadores com fundamentação nessa tecnologia, manufaturar o produto em suas instalações ou por subcontratação de terceiros para fornecer ao cliente do mercado B2C ou B2B.

O resultado do processo juntamente com a reflexão da pesquisadora no decorrer do da etapa 6 do processo é resumido na Figura 32.

\begin{tabular}{|c|c|c|c|}
\hline PROCESSO & QUESTÃo & RESPOSTA AO PROCESSO & REFLEXÃO DA PESQUISADORA \\
\hline $\begin{array}{c}\text { TIPO DO MODELO } \\
\text { DE NEGÓCIOS }\end{array}$ & Qual é o tipo do modelo de negócios a ser adotado? & Modelo: Produto; Submodelo: Manufatura & $\begin{array}{l}\text { Processo simplificado por meio da seleção } \\
\text { de tipologia previamente predefinida pelo } \\
\text { autor. }\end{array}$ \\
\hline
\end{tabular}

Figura 32. Quadro ilustrativo que resume os resultados da etapa 6 do ciclo 2 (Fonte: adaptado de Pedroso, 2018).

\subsection{2 $\quad$ Etapa $7 \quad$ Proposta de valor}

O processo de geração de modelo de negócios utilizado nesse estudo considera que a que a proposta de valor aos clientes é composta por quatro elementos (Pedroso, 2018):

(1) Segmento alvo de clientes: pondera sobre quem são os clientes alvo e onde estão localizados.

(2) Problema a ser resolvido: aborda os problemas importantes ou necessidades dos clientes alvo que devem ser atendidas, bem como as circunstâncias ou ocasiões nas quais esses problemas ou necessidades ocorrem.

(3) A solução: contempla os produtos e serviços oferecidos para resolver o problema, considerando o que é entregue, como a entrega ocorre e como é percebida (a experiência do cliente) pelos consumidores.

(4) Preço: contempla o quanto e como os clientes necessitam pagar os clientes necessitam pagar para resolver seus problemas importantes ou satisfazer suas necessidades. 
A proposta de valor pode ser gerada seguindo tipos distintos de métodos. O processo de geração de proposta de valor utilizado nesse estudo segue a sugestão adotada por Pedroso, 2016, e Pedroso, 2018 em que são empregados: o canvas da proposta de valor (Osterwalder, Pigneur, Bernarda, \& Smith, 2014) e a matriz de avaliação de valor (Kim \& Mauborgne, 2005).

O canvas da proposta de valor compreende os parâmetros: segmento de clientes, ganhos, dores, trabalho a ser feito, geradores de ganhos, aliviadores de dores, produtos \& serviços e proposta de valor.

A matriz de avaliação de valor (ou curva de valor) é uma ferramenta que considera os atributos competitivos da solução da empresa estudada e dos concorrentes, e a percepção dos clientes sobre os mesmos. Dessa forma, a empresa estudada pode ter a ampliação do desempenho dos atributos competitivos muito valorizados pelos clientes e redução e/ou eliminação de atributos menos valorizados, ou até mesmo pela criação de novos atributos (Pedroso, 2016).

A pesquisadora seguiu a seguinte ordem para definição da proposta de valor: (i) matriz de avaliação de valor utilizando os atributos delimitados na etapa 4 do ciclo 1, e (ii) canvas da proposta de valor onde a proposta de valor foi definida pela composição dos 4 elementos segmento alvo de clientes, problema a ser resolvido, a solução e preço. O resultado da definição da proposta de valor da Sampa Tech utilizando essas ferramentas está ilustrado nas Figuras 33 e 34, respectivamente. 


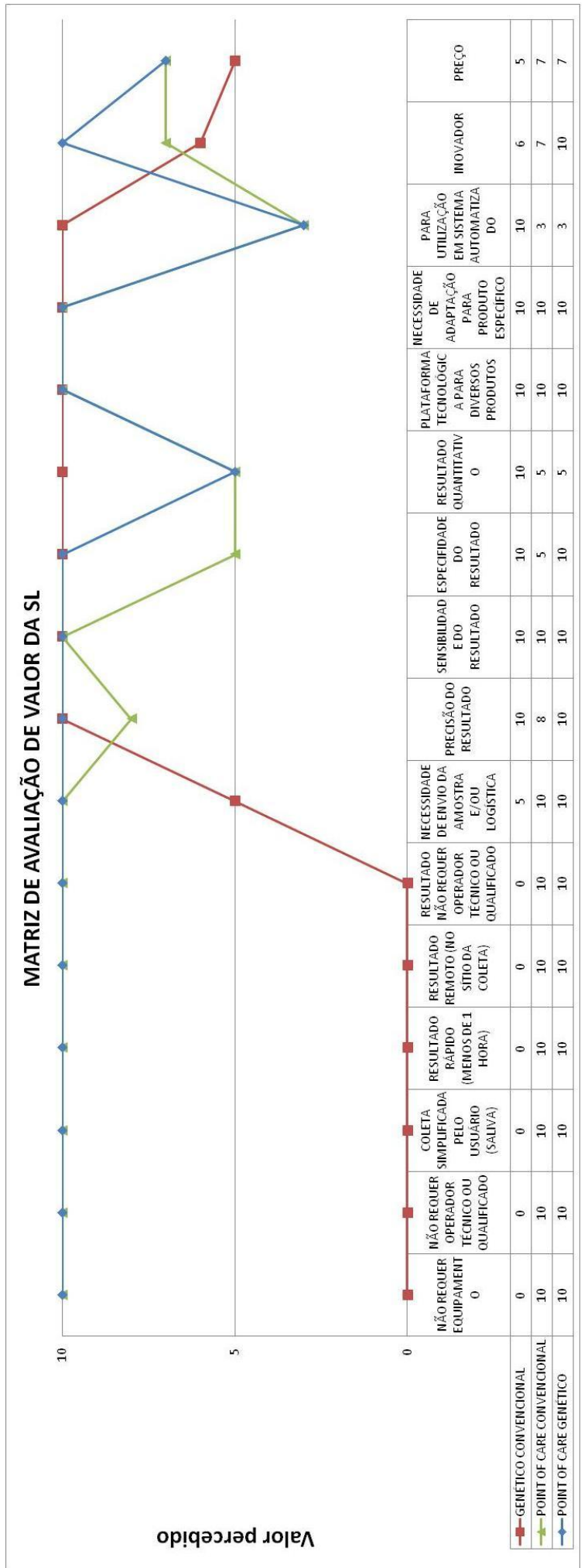

Figura 33. Matriz de avaliação de valor da Sampa Tech (Fonte: A autora). 


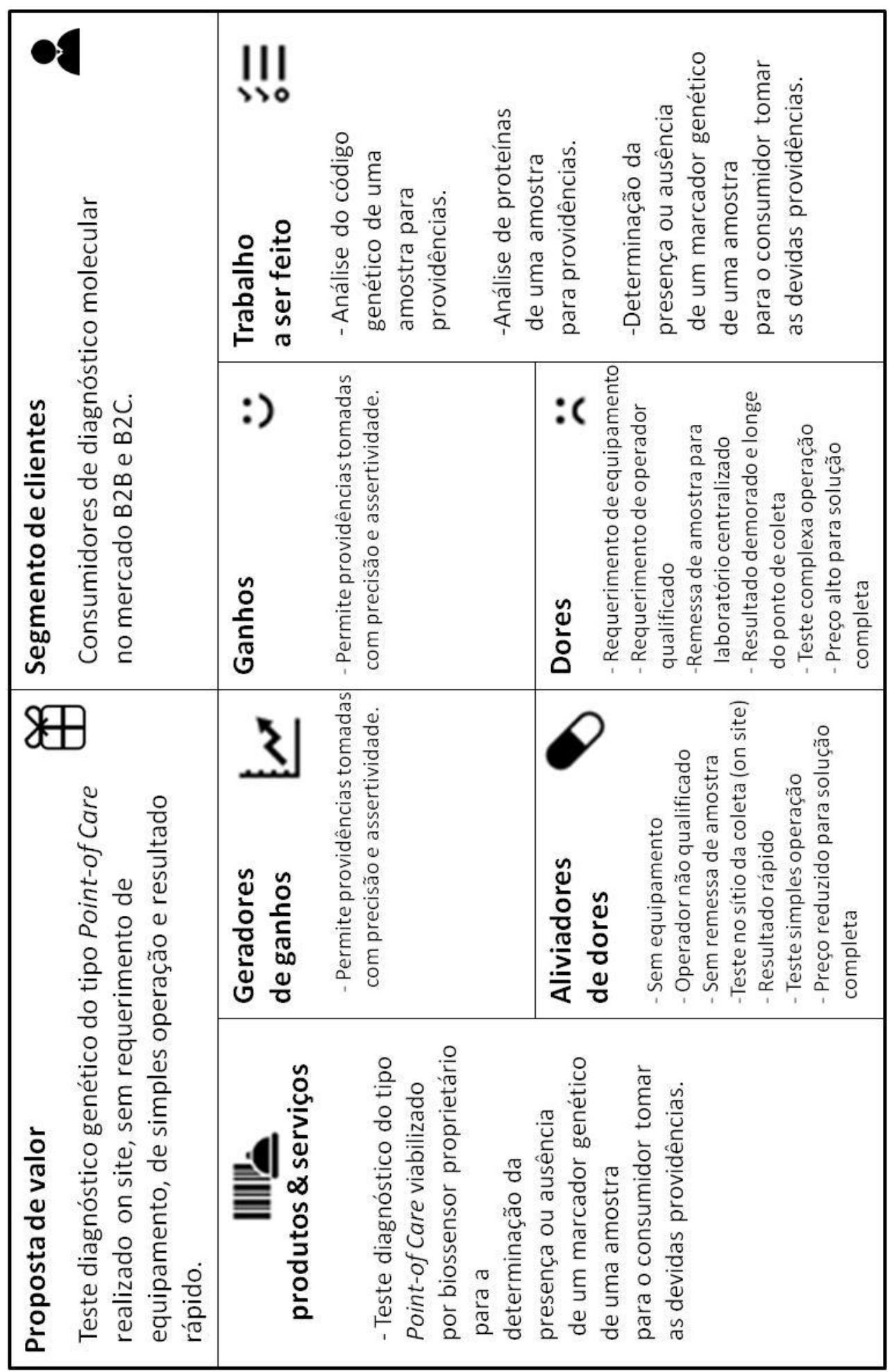

Figura 34. Canvas da proposta de valor da Sampa Tech (Fonte: adaptado de Osterwalder, Pigneur, Bernarda, \& Smith, 2014).

O resultado do processo juntamente com a reflexão da pesquisadora no decorrer do da etapa 7 do processo é resumido na Figura 35. 


\begin{tabular}{|c|c|l|l|}
\hline PROCESSO & QUESTÃO & RESPOSTA AO PROCESSO & REFLEXÃo DA PESQUISADORA \\
\hline PROPOSTA DE VALOR & Qual é a proposta de valor aos clientes? & $\begin{array}{l}\text { Teste diagnóstico genético do tipo Point-of Care } \\
\text { realizado on site, sem requerimento de } \\
\text { equipamento, de simples operação e resultado etapa foi extremamente relevante para } \\
\text { rápido. }\end{array}$ & $\begin{array}{l}\text { Essa } \\
\text { auxiliar va visualização e definição do } \\
\text { mercado e definir proposta de valor. Esse } \\
\text { fato também foi observado nas mentoria em } \\
\text { negócios de base científica. }\end{array}$ \\
\hline
\end{tabular}

Figura 35. Quadro ilustrativo que resume os resultados da etapa 7 do ciclo 2 (Fonte: adaptado de Pedroso, 2018).

\subsubsection{Etapa $8 \quad$ Posicionamento competitivo}

Posicionamento estratégico (ou competitivo) consiste na definição da posição que a organização (ou suas marcas, produtos e serviços) ocupa, ou deseja ocupar, em relação aos concorrentes em determinado mercado (Pedroso, 2016).

O mapa de posicionamento competitivo pode ser utilizado como ferramenta para apoiar a definição do posicionamento competitivo de uma organização por meio dos parâmetros de custo e diferenciação. Nesse mapa a empresa pode ser classificada como líder em custo, em diferenciação ou intermediária. A representação gráfica pode ser realizada por um gráfico de reta por inserção de dados sobre preço e dos benefícios do produto (eficiência de cada atributo) comparativamente com os produtos no mercado que atentem totalmente ou parcialmente o problema.

O custo de um teste genético depende de sua complexidade, ou seja, se são necessários um ou mais marcadores genéticos, ou ainda, uma família de sequências genéticas (ou genes) para a obtenção de um laudo conclusivo. As metodologias para a realização do teste genético variam também de acordo com a complexidade, e podem compreender PCR, sequenciamento ou micro-array. O valor dos testes varia entre USD\$ 100 e USD \$ 2.000,00, que depende de sua complexidade.

Existem no mercado empresas que fornecem laudos genéticos consistindo de um dossiê de ancestralidade e traços associados à saúde, tais como 23 andme que comercializa por USD \$139, sendo que a amostra de saliva é enviada ao laboratório centralizado e o resultado é emito em algumas semanas. Vale ressaltar que o modelo econômico dessa empresa está centrado na venda desses dados genéticos a grandes farmacêuticas.

Há no mercado empresas que comercializam soluções na forma se minisequenciadores de DNA (ex. MinION da Oxford Nanopore) da ou ainda de equipamentos de 
mini-PCR para serem utilizados de forma remota que variam em preço entre USD $\$ 1.000$ e USD $\$ 4.500$ (mais custos de reagentes).

Há no mercado teste rápido inovador tipo point-f-care com fundamentação em detecção de proteína tal como HIV (OraQuick In-home HIV test, USD\$42). Contudo, testes com pouca diferenciação tecnológica que está no mercado por muitos anos tal como teste de gravidez possui valor médio de USD $\$ 13$.

O posicionamento competitivo da Sampa Tech pode ser assumido como diferenciação de produto, com posição intermediária em preço relativo às soluções de diagnóstico genético e diagnóstico point-f-care com fundamentação em proteína, com valores entre USD50 e USD150.

O posicionamento estratégico também pode ser traçado por modelos que descrevem outros parâmetros utilizados por empresas para competir, tais como o modelo de disciplinas de valor (Treacy \& Wiersema, 2007) e modelo delta (Hax \& Wilde, 1999).

O modelo de disciplinas de valor considera que o posicionamento da empresa ocorre pelos parâmetros de: liderança em produto, intimidade com o consumidor ou excelência operacional. Por sua vez, a liderança em produto ocorre por diferenciação do produto que resulta no "melhor produto"; a intimidade com o consumidor ocorre por resposta ao consumidor que gera a melhor solução total; e a excelência operacional ocorre por competência operacional que deriva o melhor custo total.

O modelo Delta considera que as empresas podem assumir as posições estratégicas: melhores produtos, soluções totais para o comprador e "lock in" de sistemas. Em relação a melhores produtos, define-se que a concorrência é baseada na economia dos produtos, ou seja, na liderança em custos ou diferenciação de produtos. Em soluções totais para o comprador, a concorrência está baseada na economia do comprador na redução de seus custos ou melhora de seus lucros. Em "lock in" de sistemas a concorrência está baseada na economia de sistemas que alinha os complementadores, repele os concorrentes e busca estabelecer um padrão proprietário.

O processo utilizado no presente estudo também considera esses dois modelos de posicionamento competitivo, e contempla a consulta e justaposição da proposta da startup em sub modelos pré-definidos associados a seus parâmetros de competitividade descritos na Figura 36. Nota-se que alguns desses submodelos foram previamente descritos por 
Gassmann, Frankenberger, \& Csik, 2014 de uma forma genérica quando define como padrões de modelos de negócios existentes no mundo atual.

\begin{tabular}{|c|c|c|c|}
\hline \multicolumn{2}{|c|}{ TIPOLOGIA DE MODELO DE NEGÓCIOS } & SUBMODELO & MODELO DESCRITO POR GASSMANN, 2014 \\
\hline \multirow{5}{*}{ DISCIPLINA DE VALOR } & EXCELÊNCIA OPERACIONAL & Baixo custo & $\# 31$ no frills \\
\hline & \multirow{3}{*}{$\begin{array}{l}\text { LIDERANÇA EM PRODUTOS } \\
\text { (modelo delta) }\end{array}$} & Melhores produtos & \\
\hline & & lock in de sistemas & $\# 27$ lock in \\
\hline & & Provedor de soluções & \#47 solution provider \\
\hline & INTIMIDADE COM CLIENTE & Experiência do cliente & \#14 experience selling \\
\hline \multirow{3}{*}{ ESTRATIFICAÇÃO SOCIAL } & & Alto luxo & \#53 utlimate luxury \\
\hline & & Boa relação Custo-benefício & \\
\hline & & Base da pirâmide & $\# 40$ target the poor \\
\hline \multirow{2}{*}{ MULTIMERCADO } & & Multimarca & \\
\hline & & Robin hood & \#44 Robin Hood \\
\hline
\end{tabular}

Figura 36. Tipologia e Submodelo de Modelo de Negócios associado ao posicionamento competitivo (Fonte: adaptado de Pedroso, 2018).

Após análise desses submodelos, a pesquisadora definiu que o modelo em que a Sampa Tech é Disciplina de valor e liderança em produtos, e submodelo melhores produtos.

O resultado do processo juntamente com a reflexão da pesquisadora no decorrer do da etapa 8 do processo é resumido na Figura 37.

\begin{tabular}{|c|c|c|c|}
\hline PROCESSO & QUESTÃo & RESPOSTA AO PROCESSO & REFLEXÃO DA PESQUISADORA \\
\hline \multirow[t]{2}{*}{ POSICIONAMENTO COMPETITIVO } & Quem são os potenciais concorrentes da solução? & $\begin{array}{l}\text { Empresas de diagnóstico molecular genético e } \\
\text { diagnóstico molecular point-of-care. }\end{array}$ & \multirow{3}{*}{$\begin{array}{l}\text { Útil para visualização do mercado apesar de } \\
\text { que as soluções consideradas não eram } \\
\text { soluções substituintes, e validação do preço } \\
\text { O mapa de posicionamento competitivo } \\
\text { seguindo o modelo de Porter foi interessante } \\
\text { para confirmação de que a solução deve } \\
\text { assumir um preço mais alto por oferecer um } \\
\text { produto diferenciado. }\end{array}$} \\
\hline & Qual é a faixa de preço da solução dos concorrentes? & Faixa entre USD\$13 e USD\$300 & \\
\hline DIFERENCIAIS COMPETTTIVOS & Quais são os diferenciais competitivos da solução? & $\begin{array}{l}\text { Remoto, Rápido, Preciso com fundamentação em } \\
\text { DNA, Sem equipamento. }\end{array}$ & \\
\hline
\end{tabular}

Figura 37. Quadro ilustrativo que resume os resultados da etapa 8 do ciclo 2 (Fonte: adaptado de Pedroso, 2018).

\subsubsection{Etapa $9 \quad$ Modelo de geração de receita}

O preço é um atributo competitivo e pode ser definido por quanto a empresa cobra para entregar os benefícios por meio dos produtos e serviços. O preço percebido pelo cliente é composto pelo preço de compra, condições de pagamento e custo de utilização. 
Os modelos de geração de receita adotados no processo do presente estudo e por (Pedroso, 2017) são: (1) preço fixo, (2) preço variável e (3) financiamento coletivo tal como ilustrado na figura 38 .

\begin{tabular}{|c|c|c|c|}
\hline \multicolumn{2}{|c|}{ TIPOLOGIA DE GERAÇÃO DE RECEITA } & SUBMODELO & MODELO DESCRITO POR GASSMANN, 2014 \\
\hline \multirow{6}{*}{ PREÇO FIXO } & VENDA DE PRODUTO OU ATIVO & venda de produto ou ativo & \\
\hline & ALUGUEL & aluguel & $\# 40$ rent instead of buy \\
\hline & PACOTE & pagamento por pacote & $\# 15$ flat rate \\
\hline & USO DO SERVIÇO & pagamento por uso do serviço & $\# 35$ pay per use \\
\hline & SUBSCRIÇÃO & pagamento por subscrição & \#48 subscription \\
\hline & PER CAPITA & pagamento per capita & \\
\hline \multirow{15}{*}{ PREÇO VARIÁVEL } & \multirow{4}{*}{ PREÇO COMPOSTO } & pagamento por atributo & \#01 add on \\
\hline & & freemium & $\# 18$ freemium \\
\hline & & receita indireta oculta & \#21 hidden revenue \\
\hline & & aparelho e lâmina & $\# 39$ razor and blade \\
\hline & \multirow{5}{*}{ PREÇO DINÂMICO } & negociação & \#36 pay what you want \\
\hline & & leilão & \#04 auction \\
\hline & & oferta e demanda, & \\
\hline & & rendimento & \\
\hline & & permuta & $\# 05$ barter \\
\hline & \multirow{6}{*}{$\begin{array}{l}\text { PREÇO ASSOCIADO AO } \\
\text { DESEMPENHO }\end{array}$} & intermediação ou "brokering" & $\# 02$ affiliation \\
\hline & & propaganda & \\
\hline & & licenciamento de propriedade intelectual & \#26 licensing \\
\hline & & compartilhamento de receita & \#41 revenue sharing \\
\hline & & oferta e demanda & \\
\hline & & emuneração por desempenho P2P & $\# 38$ performance-based contracting \\
\hline \multirow{2}{*}{$\begin{array}{l}\text { FINANCIAMENTO } \\
\text { COLETIVO }\end{array}$} & PRODUTOS E SERVIÇOS & financiamento coletivo de produtos e serviços & $\# 08$ crowdfunding \\
\hline & DOAÇÕES & $\begin{array}{l}\text { doações (financiamento filantrópico } \\
\text { ou para projetos sociais) }\end{array}$ & \\
\hline
\end{tabular}

Figura 38. Tipologia e Submodelo de Geração de Receita (Fonte: adaptado de Pedroso, 2018).

A pesquisadora e o co-fundador da Sampa Tech visualizam o modelo de geração de receita da Sampa Tech como sendo preço fixo e submodelo venda de produto.

O resultado do processo juntamente com a reflexão da pesquisadora no decorrer do da etapa 9 do processo é resumido na figura 39.

\begin{tabular}{|c|c|c|c|}
\hline PROCESSO & QUESTÃo & RESPOSTA AO PROCESSO & REFLEXÃO DA PESQUISADORA \\
\hline \multirow{2}{*}{ MODELO DE GERAÇÃO DE RECEITA } & Qual é o preço médio definido para a solução? & Faixa entre USD\$50 e USD\$200 & \multirow{2}{*}{$\begin{array}{l}\text { Não foi idetificado elemento relevante } \\
\text { adicional para ser discutido. }\end{array}$} \\
\hline & Qual é o modelo definido para geração de receita? & Modelo preço fixo e submodelo venda de produto & \\
\hline
\end{tabular}

Figura 39. Quadro ilustrativo que resume os resultados da etapa 9 do ciclo 2 (Fonte: adaptado de Pedroso, 2018).
6.2 .5
Etapa 10
Validação da solução 
A articulação da proposta de valor, e consequente apresentação da solução inovadora, deve responder adequadamente 8 questões principais: (1) Segmentos de clientes e consumidores, (2) Problemas a serem resolvidos, (3) Tipo do modelo de negócio, (4) Solução, (5) Posicionamento Competitivo, (6) Modelo de geração de receita (7) Diferenciais competitivos, e (8) Competências (pessoais ou organizacionais).

A representação gráfica dessa articulação é denominada no atual processo como canvas da validação da proposta de valor. O canvas da validação da solução da Sampa Tech foi desenhado tal como ilustrado na Figura 40. 


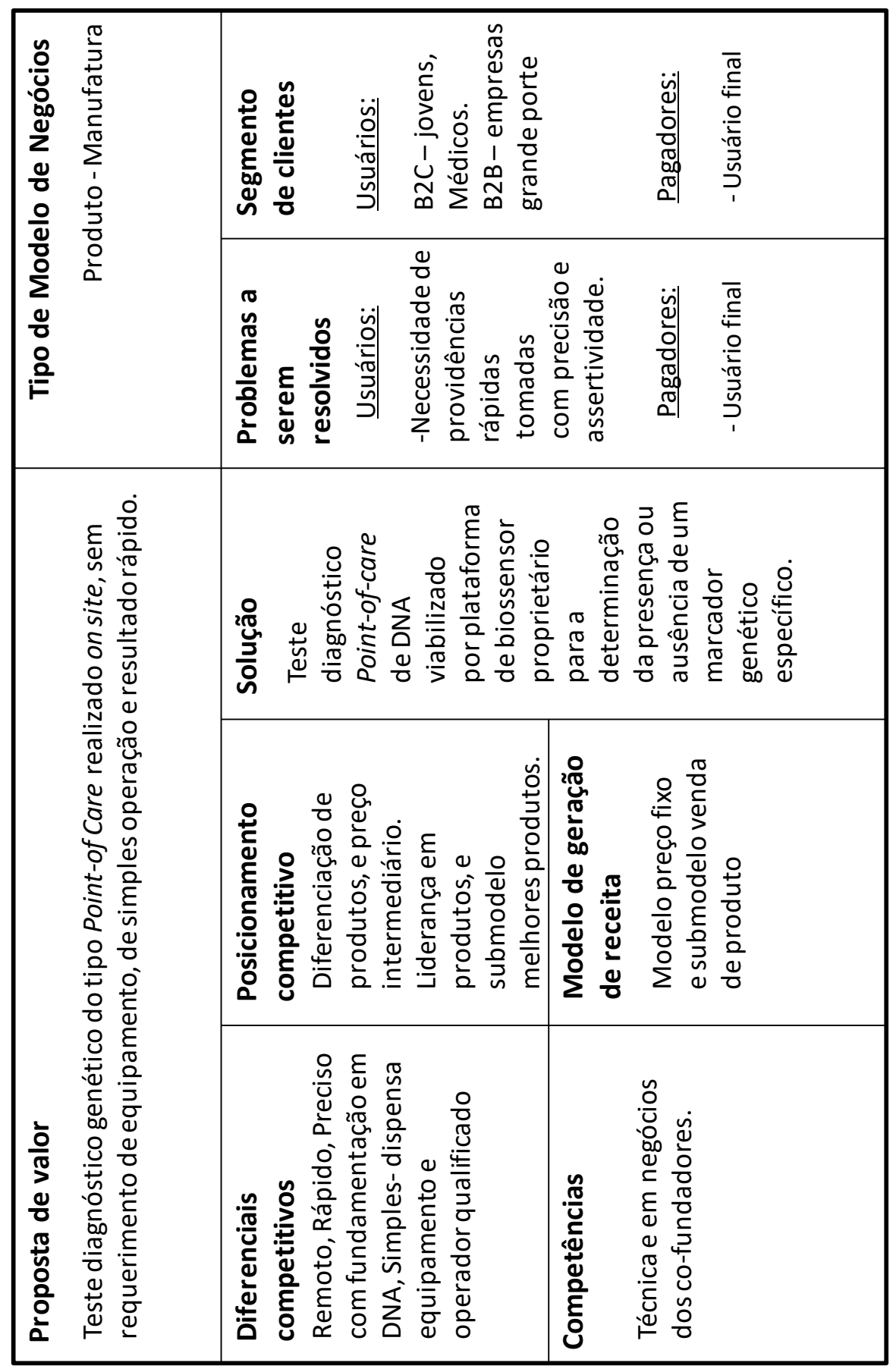

Figura 40. Canvas da validação da solução (Fonte: adaptado de Pedroso, 2018).

O resultado do processo juntamente com a reflexão da pesquisadora no decorrer etapa 10 do processo é resumido na Figura 41. 


\begin{tabular}{|c|c|c|c|}
\hline PROCESSO & QUESTÃO & RESPOSTA AO PROCESSO & REFLEXÃo DA PESQUISADORA \\
\hline SOLUÇÃO PROPOSTA & Qual é a solução proposta? & $\begin{array}{l}\text { Teste diagnóstico Point-of-care de DNA viabilizado } \\
\text { por plataforma de biossensor proprietário para a } \\
\text { determinação da presença ou ausência de um } \\
\text { marcador genético específico. }\end{array}$ & \multirow{5}{*}{$\begin{array}{l}\text { A visualização do canvas de validação da } \\
\text { proposta de valor foi relevante para a } \\
\text { validação da solução. }\end{array}$} \\
\hline \multirow{4}{*}{ VALIDAÇÃO DA SOLUÇÃO PROPOSTA } & Quais foram os elementos testados? & $\begin{array}{l}\text { O tipo de modelo de negócios, segmento de } \\
\text { clientes, problemas a serem resolvidos, } \\
\text { posicionamento competitivo, modelo de geração } \\
\text { de receita, diferenciais competitivos e } \\
\text { competências. }\end{array}$ & \\
\hline & Quais foram os métodos de validação? & O percurso do processo. & \\
\hline & Quais elementos foram validados? & Todos. & \\
\hline & Quais evidências demonstram as validações? & Receptividade dos clientes. & \\
\hline
\end{tabular}

Figura 41. Quadro ilustrativo que resume os resultados da etapa 10 do ciclo 2 (Fonte: adaptado de Pedroso, 2018).

\subsection{Ciclo 3}

6.3.1 Etapas 11 e 12 Modelo econômico: Estrutura de custos e Fórmula de lucro

Segundo o processo descrito por Pedroso, 2018, o modelo econômico é definido como criar e capturar valor. A criação de valor pode ser definida como estrutura de custos (custos fixos e variáveis, custo de capital e capital investido) e fórmula de lucro (valor agregado em custos), e a captura de valor como modelo de geração de receita (preço).

Os métodos para análise do modelo econômico de uma organização pode ser definido com o cálculo do EVA (valor econômico agregado) que mede o lucro econômico esperado de um negócio. A fórmula para cálculo de EVA sugerida no processo utilizado nesse estudo está ilustrada na Figura 42. 
A

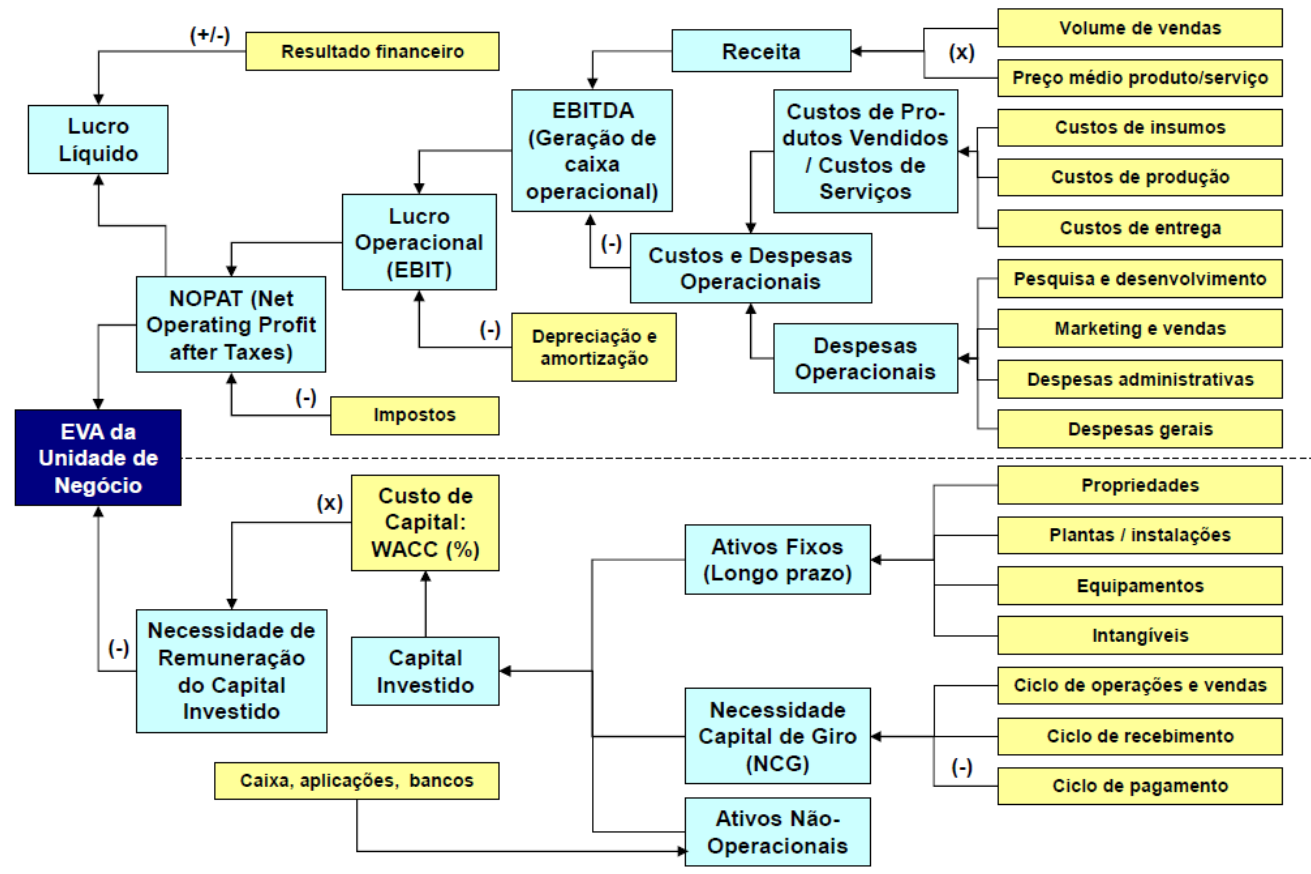

Figura 42. Esquematização da estrutura de cálculo do EVA (Fonte: Pedroso, 2018).

Nessa etapa os fundadores refletiram sobre a estrutura de EVA, e realizaram os cálculos, mais particularmente com referência a: receita, custos de produtos vendidos, e custos e despesas operacionais (a parte A da figura 42) tanto com referência ao mercados B2C quanto para o mercado B2B.

Os fundadores concluíram que considerando o mercado B2C, haveria a necessidade de capital intensivo em marketing e vendas, despesas operacionais, despesas gerais que inviabilizaria o negócio. Para o EBITIDA ser positivo, os fundadores deveriam captar um valor de investimento inicial muito elevado. Ainda, mesmo com esse investimento o EBITDA não seria atrativo. Interessante notar que as informações que ajudaram a munir essa reflexão também foram fornecidas por stakeholders do ecossistema de empreendedorismo com que os fundadores discutiram alguns pontos ao longo do projeto desde a fundação da empresa (empresas de grande porte e investidores).

Com relação ao mercado B2B, os fundadores concluíram que o EBITDA seria atrativo por consequência do valor reduzido de marketing e vendas, despesas operacionais e despesas gerais quando comparado ao B2C. Os fundadores deveriam captar um valor de investimento inicial elevado por razão da natureza do negócio - produto inovador em biotecnologia - mas a evolução do EBITIDA seria atrativo no decorrer de cinco anos. 
A pesquisadora também considerou a tipologia de modelo econômico descrita por (Pedroso, 2018) está ilustrada na Figura 40. A pesquisadora e o co-fundador definiram que o modelo econômico da Sampa Tech é de atuação sobre benefícios com impacto no volume de vendas.

\begin{tabular}{|c|c|c|c|c|}
\hline \multicolumn{2}{|c|}{ TIPOLOGIA DO MODELO ECONÔMICO } & ATUAÇÃO & IMPACTO & MODELO DESCRITO POR GASSMANN, 2014 \\
\hline \multirow{20}{*}{ BASEADO NO EVA } & \multirow{2}{*}{ EFICIÊNCIA EM VENDAS } & Benefícios & Volume de vendas & \\
\hline & & Preço & Preço médio produto/serviço & \\
\hline & \multirow{7}{*}{ EXCELÊNCIA OPERACIONAL } & \multirow{7}{*}{ Excelência Operacional } & Custos de insumo & \\
\hline & & & Custos de produção & \\
\hline & & & Custos de entrega & \\
\hline & & & Pesquisa e desenvolvimento & \\
\hline & & & Marketing e vendas & \\
\hline & & & Despesas Admnistrativas & \\
\hline & & & Despesas Gerais & \\
\hline & \multirow{4}{*}{ FIIIÊNCIA NO USO DOS ATIVO } & \multirow{4}{*}{ Eficiência na Utilização dos Ativos } & Propriedades & \\
\hline & & & Plantas/Instalações & \\
\hline & & & Equipamentos & \\
\hline & & & Intangíveis & \\
\hline & \multirow{3}{*}{ CAPITAL DE GIRO } & \multirow{3}{*}{ Fluxo de Caixa } & Ciclo de Operaçōes e Vendas & \multirow{3}{*}{ \#06 caixa eletrônico } \\
\hline & & & Ciclo de Recebimento & \\
\hline & & & Ciclo de Operações e Vendas & \\
\hline & \multirow{4}{*}{ EFICIÊNCIA FINANCEIRA } & \multirow{4}{*}{ Otimização Financeira } & Recurso Financeiro & \\
\hline & & & Impostos & \\
\hline & & & Custo de Capital (WACC) & \\
\hline & & & Caixa, Aplicaçõos, Banco & \\
\hline \multirow{2}{*}{$\begin{array}{c}\text { BASEADO NO } \\
\text { FINANCIAMENTO }\end{array}$} & EQUITY CROWDFUNDING & Investimento colaborativo & Expansão ou abertura de empresas & $\# 08$ Crowdfunding \\
\hline & LENDING CROWDFUNDING & Empréstimo social & Financiamento coletivo para empréstimos & \\
\hline
\end{tabular}

Figura 43. Tipologia do Modelo Econômico (Fonte: adaptado de Pedroso, 2018).

O resultado do processo juntamente com a reflexão da pesquisadora no decorrer das etapas 11 e 12 do processo é resumido na Figura 44.

\begin{tabular}{|c|c|c|c|}
\hline PROCESSO & QUESTÃo & RESPOSTA AO PROCESSO & REFLEXÃO DA PESQUISADORA \\
\hline PROBLEMA VALIDADO & Qual é o SOM do mercado-alvo selecionado? & USD $\$ 700 \mathrm{Mi}$ & \multirow{5}{*}{$\begin{array}{l}\text { Não foi idetificado elemento relevant } \\
\text { adicional para ser discutido. }\end{array}$} \\
\hline \multirow{2}{*}{ SOLUÇÃO VALIDADA } & Qual é o preço médio para a contratação da solução? & Faixa entre USD\$50 e USD\$200 & \\
\hline & Como essa receita é gerada? & Preço fixo, e venda de produto & \\
\hline \multirow{2}{*}{ ESTRUTURA DE CUSTOS PREVISTA } & Qual é a estimativa (inicial) da estrutura de custos? & $\begin{array}{l}\text { EBITDA negativo para } \mathrm{B} 2 \mathrm{C} \\
\text { EBITDA positivo para B2B }\end{array}$ & \\
\hline & Qual é a estimativa (inicial) do capital a ser investido? & USD\$ $1 \mathrm{Mi}$ & \\
\hline
\end{tabular}

Figura 44. Quadro ilustrativo que resume os resultados das etapas 11 e 12 do ciclo 3 (Fonte: adaptado de Pedroso, 2018).

\section{$6.4 \quad$ Ciclo 4}

6.4.1 $\quad$ Etapa $3 \quad$ Segmento de clientes 
Em face do resultado do ciclo 3, etapa 11, a pesquisadora iniciou o ciclo 4 do presente estudo em que retornou o mesmo para a etapa 3 do processo para determinação do segmento de clientes.

Nessa etapa a pesquisadora e o co-fundador decidiram por pivotar o tipo de modelo de negócios que antes era B2C e B2B, e manter somente o B2B.

\subsubsection{Etapa $7 \quad$ Proposta de valor}

A pesquisadora decidiu por rever a proposta de valor para não somente revisar o segmento de clientes, mas também para refinar a própria proposta de valor com base nas dores dos clientes B2B. Essa revisão também foi motivada pela concomitante validação da startup em campo com empresas privadas de grande porte e investidores.

É relevante também ressaltar que em face da solução da Sampa Tech ser uma plataforma tecnológica, a mesma pode ser aplicada em diversos segmentos da indústria, tais como agropecuária, saúde e entretenimento com produtos distintos para cada ou em cada segmento.

A pesquisadora seguiu a definição da proposta de valor utilizando a ferramenta de: (i) matriz de avaliação de valor definida no ciclo 02 etapa 07 e (ii) novo canvas da proposta de valor onde a proposta de valor foi definida no ciclo 02 etapa 07 e revista por acréscimo das informações coletadas no decorrer da validação da startup, tal como ilustrado na Figura 45. 


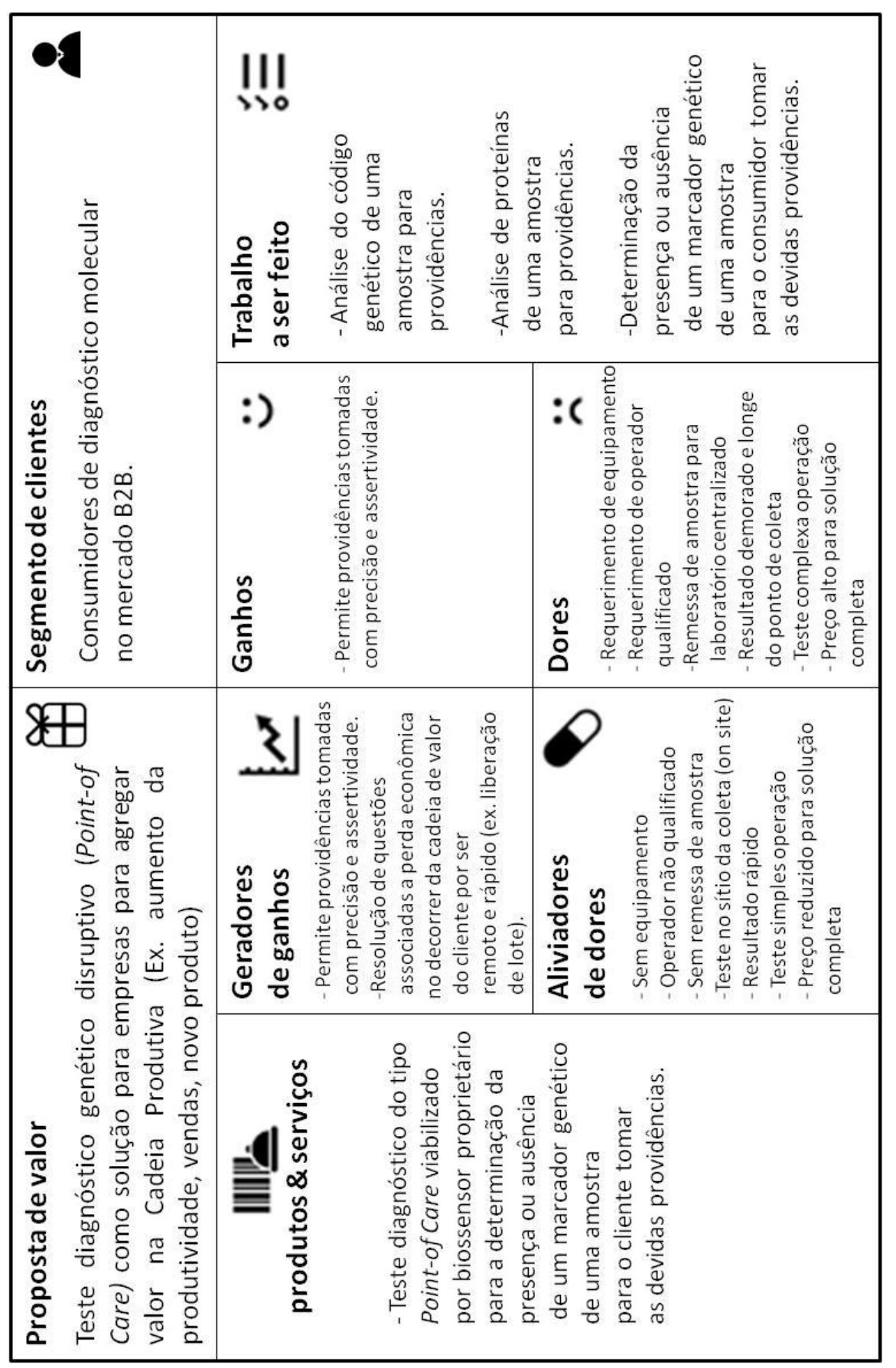

Figura 45. Canvas da segunda proposta de valor da Sampa Tech (Fonte: adaptado de Osterwalder et al., 2014).

\subsubsection{Etapa $9 \quad$ Modelo de Geração de Receita}

A pesquisadora concluiu que o modelo de receita associada à segunda proposta de valor seria mista composta de: (1) preço variável associado ao desempenho por licenciamento 
de propriedade intelectual que inclui pagamento por royalties ou upfront fees, (ii) preço fixo, venda de produto, e (iii) preço fixo, venda de serviço associado à adapatação do biossensor ao produto específico em si.

Vale ressaltar que em face da validação em campo a excelência operacional deve também ser explorada pela Sampa Tech para que seja sustentável e escalável de forma a permitir o lançamento de diversos produtos.

O resultado do processo juntamente com a reflexão da pesquisadora no decorrer da etapa 9 do processo é resumido na Figura 46.

\begin{tabular}{|c|c|c|c|}
\hline PROCESSO & QUESTÃO & RESPOSTA AO PROCESSO & REFLEXÃO DA PESQUISADORA \\
\hline & Qual é o preço médio definido para a solução? & Faixa entre USD\$50 e USD\$200 & \\
\hline MODELO DE GERAÇÃO DE RECEITA & Qual é o modelo definido para geração de receita? & $\begin{array}{l}\text { (i) Preço variável associado ao desempenho por } \\
\text { licenciamento de propriedade intelectual que inclui } \\
\text { pagamento de royalties ou upfront fees; (ii) preço } \\
\text { fixo, venda de produto; (iii) preço fixo, venda de } \\
\text { serviço associaado a adaptação do biossensor ao } \\
\text { produto espepecífico (projeto de co- } \\
\text { desenvolvimento). }\end{array}$ & $\begin{array}{l}\text { Não foi identificado elemento relevante } \\
\text { adicional para ser discutido. }\end{array}$ \\
\hline
\end{tabular}

Figura 46. Quadro ilustrativo que resume os resultados da etapa 9 do ciclo 4 (Fonte: adaptado de Pedroso, 2018).

\subsubsection{Etapa 11 e 12 Modelo Econômico: Estrutura de Custos e fórmula de lucro}

A pesquisadora e o co-fundador definiram que o modelo econômico da Sampa Tech continuaria a ser de atuação sobre benefícios com impacto no volume de vendas.

Nessa etapa os fundadores refletiram novamente sobre a estrutura de EVA mais particularmente com referência a: receita, custos de produtos vendidos, e custos e despesas operacionais (a parte A da Figura 42) para o mercado B2B.

Os fundadores concluíram que para o EBITIDA ser positivo, os fundadores deveriam captar um valor de investimento inicial pequeno considerando o usualmente captado para biotecnologia (captação anjo nos EUA). Com esse investimento, e o desenvolvimento de 4 produtos, o EBITDA seria atrativo e o breakeven ocorreria em 3 anos em cenário projetado de 5 anos. Interessante notar que as informações que ajudaram a munir essa reflexão também foram fornecidas por stakeholders do ecossistema de empreendedorismo com que os fundadores discutiram alguns pontos ao longo do projeto desde a fundação da empresa (empresas de grande porte e investidores). 
Com relação aos produtos e segmentos a seres desenvolvidos e explorados, a pesquisadora e fundador adicionalmente construíram planilhas de: prioridade de projetos e brainstorm. A planilha de projetos tinha como objetivo classificar os projetos em ordem de prioridade de acordo com premissas assumidas relevantes com relação à maturidade do protótipo, mercado, tempo para chegar ao mercado e barreiras de entrada no mercado. A planilha de brainstorm tinha como objetivo listar os produtos relevantes e atrativos em cada segmento industrial. Vale ressaltar que esse tipo de planilha de brainstorm é utilizado na etapa 1 do processo de geração de modelo de negócios descrito por Aulet, 2013.

Essas planilhas foram bastante relevantes visto que o produto da Sampa Tech refere-se a uma plataforma tecnológica que pode dar origem a distintos produtos em diversos segmentos. Particularmente a tabela de brainstorm auxiliou no refinamento dos problemas a serem resolvidos e segmentação de clientes e persona, aliado a validação de campo com os clientes o que proporcionou resposta mais rápida a mudanças de cenário externo. A pequisador ressalta que o presente processo pode ser utilizado para avaliar cada produto a ser desenvolvido em face de determinação de segmento de clientes, levantamento do tamanho de mercado, problema a ser resolvido, modelo de geração de receita, etc.

A pesquisadora acredita que essas tabelas descritas anteriormente podem ser relevantes em alguns casos. Talvez fosse relevante a construção das mesmas no decorrer do processo, podendo inclusive auxiliar no processo.

O resultado do processo juntamente com a reflexão da pesquisadora no decorrer das etapas 11 e 12 do processo é resumido na Figura 47.

\begin{tabular}{|c|c|c|c|}
\hline PROCESSO & QUESTÃo & RESPOSTA AO PROCESSO & REFLEXÃO DA PESQUISADORA \\
\hline \multirow[b]{3}{*}{ SOLUÇÃo VALIDADA } & Qual é o SOM do mercado alvo selecionado? & US\$700 mil & \multirow{5}{*}{$\begin{array}{l}\text { Não foi identificado elemento relevante } \\
\text { adicional para ser discutido. }\end{array}$} \\
\hline & Qual é o preço médio para contratação da solução? & Faixa entre USD\$50 e USD\$200 & \\
\hline & Qual é a receita gerada? & \begin{tabular}{|l} 
(i) Preço variável associado ao desempenho por \\
licenciamento de propriedade intelectual que inclui \\
pagamento de royalties ou upfront fees; (ii) preço \\
fixo, venda de produto; (iii) preço fixo, venda de \\
serviço associaado a adaptação do biossensor ao \\
produto espepecífico (projeto de co- \\
desenvolvimento).
\end{tabular} & \\
\hline \multirow{2}{*}{ ESTRUTURA PREVISTA DE CUSTOS } & Qual é a estimativa (inicial) da estrutura de custos? & EBITIDA positivo para B2B & \\
\hline & Qual é a estimativa (inicial) do capital a ser investido? & USD\$ 1 Mi para B2B & \\
\hline
\end{tabular}

Figura 47. Quadro ilustrativo que resume os resultados das etapa 11 e 12 do ciclo 4 (Fonte: adaptado de Pedroso, 2018). 


\subsubsection{Etapa $13 \quad$ Modelo de Operações}

O modelo de operações pode ser definido como as capacidades organizacionais de recursos (entradas) e processos compostos de atividades (transformação por agregação de valor) que vão gerar a proposta de valor (produtos, serviços e conexões aliado aos resultados e desempenho). A geração de valor pode ser classificada de processos de manufatura e/ou processos de serviços.

A figura 48 ilustra a tipologia de modelo de operações utilizado no processo utilizado nesse estudo tal como descrito por Pedroso, 2018).

A pesquisadora classifica o modelo de operações da Sampa Tech como complexidade submodelo operações hiperespecializadas. 


\begin{tabular}{|c|c|c|c|}
\hline \multicolumn{2}{|c|}{ TIPOLOGIGA DE MODELO DE OPERAÇÕES } & SUBMODELO & MODELO DESCRITO POR GASSMANN, 2014 \\
\hline \multirow{9}{*}{ PACOTE PRODUTO/SERVIÇO } & SERVITIZAÇÃO & Servitização & \\
\hline & INDUSTRIALIZAÇÃO DE SERVIÇOS & Industrialização de serviços & \\
\hline & & Digitalização & \#11 Digitisation \\
\hline & & Computação em nuvem & \\
\hline & & Impressão 3D & \\
\hline & & Virtualização & \\
\hline & \multirow{3}{*}{ Internet das Coisas (IoT) } & Sensor como um serviço & \\
\hline & & Objeto como um autosserviço & \\
\hline & & Objeto no ponto de venda & \\
\hline \multirow{2}{*}{$\begin{array}{c}\text { MODELAGEM DOS RECURSOS } \\
\text { E PROCESSOS } \\
\end{array}$} & Exploração dos recursos & Oferta baseada nos recursos & \# 29 Make more of it \\
\hline & Exploração dos processos & Outsourcing de processos (BPO) & \\
\hline \multirow{35}{*}{$\begin{array}{c}\text { DIRECIONADORES DE } \\
\text { EFICIÊNCIA OPERACIONAL }\end{array}$} & \multirow{5}{*}{ Economia de escala e escopo } & Franquia & \# 17 Franchising \\
\hline & & Cadeia integrada & \# 23 Integrator \\
\hline & & Loja dentro de loja & \# 46 Shop in shop \\
\hline & & Supermercado & \#49 Supermarket \\
\hline & & Venda cruzada & \# 7 Cross selling \\
\hline & \multirow{2}{*}{ Curva de experiência } & Fornecedor especializado & \# 24 Layer player \\
\hline & & Operações focadas & \\
\hline & \multirow{2}{*}{ Utilização dos recursos } & Autosserviço & \# 45 Self service \\
\hline & & Consumidor como produtor & \\
\hline & \multirow{4}{*}{ Economia circular } & Ativos compartilhados & \# 16 Fractional ownership \\
\hline & & Serviços compartilhados & \\
\hline & & Insumos circulares & \\
\hline & & Reaproveitamento & \# 51 Trash to cash \\
\hline & \multirow{3}{*}{ Posição na cadeia de valor } & Venda direta & \#12 Direct seling \\
\hline & & Sistema puxado & \# 19 From push to pull \\
\hline & & Coordenador da cadeia & \#34 Orchestrator \\
\hline & Complexidade & Operações hiperespecializadas & \\
\hline & \multirow{6}{*}{ Economia de escala e escopo } & Franquia & \# 17 Franchising \\
\hline & & Cadeia integrada & \#23 Integrator \\
\hline & & Loja dentro de loja & \# 46 Shop in shop \\
\hline & & Supermercado & \# 49 Supermarket \\
\hline & & Cauda longa & \# 28 Long tail \\
\hline & & Venda cruzada & \# 7 Cross selling \\
\hline & \multirow{2}{*}{ Curva de experiência } & Fornecedor especializado & \# 24 Layer player \\
\hline & & Operações dedicadas & \\
\hline & \multirow{2}{*}{ Utilização dos recursos } & Autosserviço & \# 45 Self service \\
\hline & & Consumidor como produtor & \\
\hline & \multirow{4}{*}{ Economia circular } & Ativos compartilhados & \# 16 Fractional ownership \\
\hline & & Serviços compartilhados & \\
\hline & & $\begin{array}{l}\text { Insumos circulares (Energia } \\
\text { renovável, insumos biológicos } \\
\text { e/oucompletamente recuperáveis) }\end{array}$ & \\
\hline & & Reaproveitamento & \# 51 Trash to cash \\
\hline & \multirow{3}{*}{ Posição na cadeia de valor } & Venda direta & \# 12 Direct seling \\
\hline & & Sistema puxado & \# 19 From push to pull \\
\hline & & Coordenador da cadeia & \#34 Orchestrator \\
\hline & Complexidade & Operações hiperespecializadas & \\
\hline
\end{tabular}

Figura 48. Tipologia do Modelo de Operações (Fonte: adaptado de Pedroso, 2018).

6.4.6 $\quad$ Etapa $14 \quad$ Modelo de Relacionamento com clientes

No processo utilizado nesse estudo, o modelo de relacionamento com cliente é definido por consistir no processo de aquisição de clientes, ou seja, canais de comunicação e relacionamento com clientes, que inclui processos de comunicação e processos de vendas.

O processo de comunicação é composto de estratégias de marca. O processo de vendas, ou processo de relacionamento com clientes compreende a aquisição (e recuperação) de clientes e retenção (e fidelização) de clientes. 
A tipologia de modelos de relacionamento com clientes está ilustrada na Figura 49.

\begin{tabular}{|c|c|c|c|}
\hline \multicolumn{2}{|c|}{ TIPOLOGIGA DE RELACIONAMENTO COM CLIENTE } & SUBMODELO & MODELO DESCRITO POR GASSMANN, 2014 \\
\hline \multirow{3}{*}{ ESTRATÉGIA DE MARCAS } & MARCA DO COMPONENTE & marca do componente & \#22 ingredient branding \\
\cline { 2 - 4 } & MARCA PRÓPRIA & marca própria & $\#$ \#5 white label \\
\hline \multirow{2}{*}{ RELACIONAMENTO COM CLIENTES } & AQUISIÇÃO DE CLIENTES & base de dados de clientes & \#25 leverage customer data \\
\cline { 2 - 4 } & FIDELIZAÇÃO DE CLIENTES & fidelidade dos clientes & \#10 customer loyalty \\
\hline
\end{tabular}

Figura 49. Tipologia do Modelo de Relacionamento com clientes (Fonte: adaptado de Pedroso, 2018).

Interessante notar que geralmente $80 \%$ da receita (e/ou lucros) está associada aos principais (ou top) $20 \%$ dos clientes de uma organização. E os $15 \%$ dos clientes costumam ser menos interessantes (ou bottom) e podem ser deficitários. A forma de medir a lucratividade cada cliente pode ser realizada pela diferença entre as receitas auferidas e os custos associados a partir do relacionamento com o cliente durante um período especificado. Esse conceito deriva da noção de lucro contábil, geralmente aplicada em relação ao cliente individual - visão a partir do presente com relação ao passado (Pfeifer, Haskins, \& Conroy, 2005).

O valor do ciclo de vida do cliente ("lifetime value", LTV) é o valor presente do fluxo de caixas futuros atribuídos ao relacionamento com o cliente, conceito com visão de futuro (Pfeifer et al., 2005). De acordo com esse conceito a lucratividade aumenta com o ciclo de vida do relacionamento com o cliente, sendo que assume valores negativos no início do relacionamento por um certo período até até a lucratividade do cliente se tornar positiva. Esse período está relacionado ao custo de aquisição do cliente (denominado de CAC ou COCA). O valor aumenta após atingir o ápice, mas decresce o que sinaliza a necessidade de atuação sobre o cliente para reverter a tendência ao declínio o que corresponde a necessidade de existir ações para a retenção do cliente.

O cálculo do LTV é realizado pela fórmula tal como ilustrado na Figura 50. 


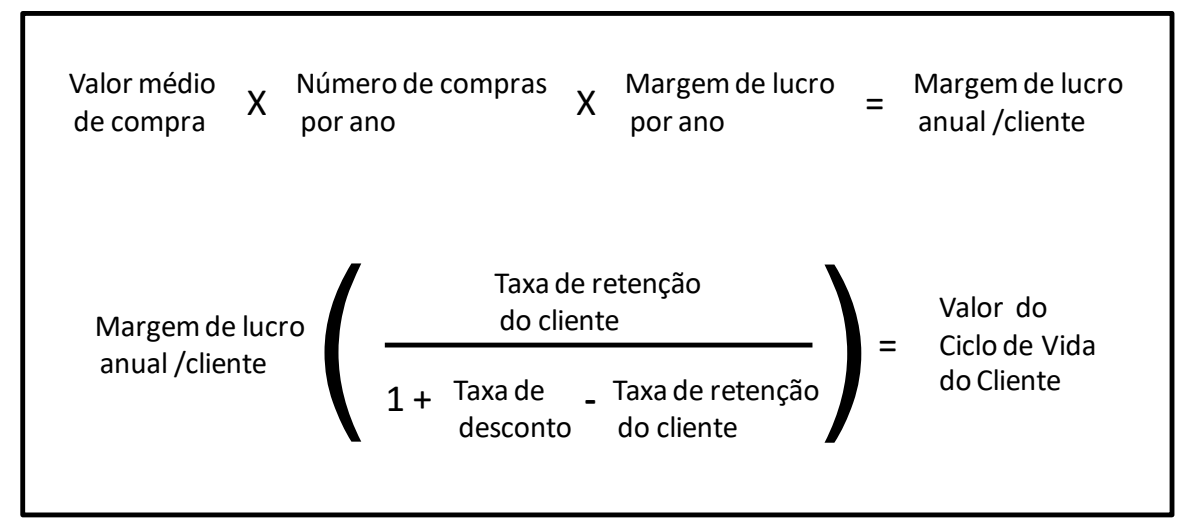

Figura 50. Fórmula de cálculo de LTV (Fonte: adaptado de Pedroso, 2018.

O cálculo do custo de aquisição do cliente (COCA) é realizado pela fórmula tal como ilustrado na Figura 51.

$$
\text { COCA }=\frac{\text { Despesas totais de marketing e vendas }(\mathrm{t})-\text { despesa da instalação da base de suporte }(\mathrm{t})}{\text { Número de novos clientes }}
$$

Figura 51. Fórmula de cálculo do COCA (Fonte: adaptado de Pedroso, 2018).

O processo utilizado no presente estudo considera como parâmetro adicional o descrito por (Aulet, 2013) de que o LTV deve ser igual a 3 vezes o COCA para que o empreendimento seja validado do ponto de vista financeiro.

A pesquisadora calculou o LTV e COCA sendo que a razão entreLTV foi maior que 3. A pesquisadora aponta que de fato o número de LTV ser maior que COCA é esperado visto que nesse tipo de startup que possui segmento de clientes $\mathrm{B} 2 \mathrm{~B}$, produto de valor agregado alto e/ou alto volume de vendas espera-se que o valor seja maior que 3.

A pesquisadora também chama a atenção para o fato que no processo descrito por (Aulet, 2013) não é sugerido o cálculo do DRE e somente o LTV/COCA visto que o mesmo reflete o comportamento financeiro geral do negócio - se manterá em pé ou não. O DRE pode ser ajustado juntamente com as premissas que o constrói. A pesquisadora ainda acrescenta que o DRE é relevante para fornecer um direcionamento de como definir as metas, gestão e alcançar a sustentabilidade e escalabilidade da startup em momento posterior a sua 
concepção. Ou seja, o DRE é relevante para a execução e não para elaboração do modelo de negócios.

O resultado do processo juntamente com a reflexão da pesquisadora no decorrer da etapa 14 do processo é resumido na Figura 52.

\begin{tabular}{|c|c|c|c|}
\hline PROCESSO & QUESTÃO & RESPOSTA AO PROCESSO & REFLEXÃO DA PESQUISADORA \\
\hline ESTRATÉGIA DE MARCAS & Qual é a estratégia de marcas da organização? & marca própria & \multirow{7}{*}{$\begin{array}{l}\text { Não foi idetificado elemento relevante } \\
\text { adicional para ser discutido. }\end{array}$} \\
\hline CANAIS & $\begin{array}{l}\text { Quais são os principais canais de relacionamentos com os } \\
\text { clientes? }\end{array}$ & contato direto, feiras, eventos & \\
\hline RECURSOS AQUISIÇ̄̃o & $\begin{array}{l}\text { Quais são os recursos e processos de aquisição (e } \\
\text { recuperação) de clientes? }\end{array}$ & prospecção ativa e contato direto & \\
\hline RECURSOS DE RETENÇÃo & $\begin{array}{l}\text { Quais são os recursos e processos de retenção (e fidelização) } \\
\text { de clientes? }\end{array}$ & bom desempenho do primeiro produto & \\
\hline COCA & Qual é o custo estimado de aquisição de clientes (COCA)? & baixo & \\
\hline cLV & $\begin{array}{l}\text { Qual é o CLV (customer lifetime value ou "valor do tempo } \\
\text { de vida do cliente)? }\end{array}$ & alto & \\
\hline CLV/COCA & O CLV é maior do que três vezes o COCA? & $\operatorname{sim}$ & \\
\hline
\end{tabular}

Figura 52. Quadro ilustrativo que resume os resultados da etapa 14 do ciclo 4 (Fonte: adaptado de Pedroso, 2018).

\subsection{7 $\quad$ Etapa $15 \quad$ Modelo de Inovação}

O modelo de inovação definido por Pedroso, 2017 compreende processos de desenvolvimento para a entrega de soluções. De acordo com o manual de Oslo, os tipos de inovação podem ser classificados como (i) inovação de valor, (2) inovação de produtos e serviços, e (3) inovação de processos.

A inovação de valor refere-se a como a organização gera valor que pode ocorrer, por exemplo, por meio de mudanças na forma de obtenção de receitas e lucros, mudanças organizacionais, tecnológicas e na cadeia de valor para suportar a inovação de modelos de negócios.

A inovação de produtos e serviços refere-se a o que a empresa entrega que pode ocorrer, por exemplo, por meio do lançamento de novos produtos e serviços, ou incorporação tecnológica e de conhecimento nos produtos e serviços.

A inovação de processos refere-se a como a empresa entrega que pode ocorrer, por exemplo, por meio do desenvolvimento de novos processos de produção e atendimento, e incorporação tecnológica e de conhecimento nos recursos, infraestrutura, processos e cadeia de valor. 
A figura 53 ilustra a tipologia de modelos de inovação utilizado no processo utilizado nesse estudo tal como descrito por Pedroso, 2018.

O submodelo de inovação da Sampa Tech é Inovação direcionada por tecnologia.

\begin{tabular}{|c|c|c|c|}
\hline \multicolumn{2}{|c|}{ TIPOLOGIA DE MODELO DE INOVAÇÃO } & SUBMODELO & MODELO DESCRITO POR GASSMANN, 2014 \\
\hline \multirow{3}{*}{ TIPOLOGIA DE INOVAÇÃO } & INOVAÇÃO DE VALOR & inovador de valor & \#03 Aikido \\
\hline & INOVAÇÃO DE PRODUTOS & inovador de produtos e serviços & \\
\hline & INOVAÇÃO DE PROCESSOS & inovador de processos & \\
\hline \multirow{7}{*}{ FONTES DE INOVAÇÃO } & INOVAÇÃO FECHADA & inovação fechada & \\
\hline & \multirow{6}{*}{ INOVAÇÃO ABERTA } & Colaboração coletiva & \# 09 Crowdsourcing \\
\hline & & Corporate venturing & \#32 Open business \\
\hline & & Código aberto & \#33 Open source \\
\hline & & Engenharia reversa & \# 42 Reverse engineering \\
\hline & & Inovação reversa & \# 43 Reverse innovation \\
\hline & & Design pelo usuário & \# 54 User design \\
\hline \multirow{5}{*}{ PROJETO EFICIENTE } & \multirow{4}{*}{ Design circular } & Design para durabilidade & \\
\hline & & Design para serviços (servitização) & \\
\hline & & Design para reuso & \\
\hline & & Design para recuperação dos materiais & \\
\hline & Design modular & Design modular & \\
\hline \multirow{3}{*}{ DIRECIONADORES DE INOVAÇÃO } & Tecnologia & Inovação direcionada por tecnologia & \\
\hline & \multirow{2}{*}{ Mercado } & Inovação direcionada pela necessidade do usuário & \\
\hline & & Inovação direcionada pela reação do mercado & \\
\hline
\end{tabular}

Figura 53. Tipologia do Modelo de Inovação (Fonte: adaptado de Pedroso, 2018).

\subsection{8 $\quad$ Etapa $16 \quad$ Modelo de Gestão}

O processo adotado nesse estudo prevê que o modelo de gestão, ou seja, a forma de como gerenciar a empresa segue 2 dimensões - de finalidade e de meios - que são mensuradas por métricas de acordo com o descrito por (Birkinshaw \& Goddard, 2009 apot Pedroso, 2018).

A dimensão finalidade compreende a definição de objetivos (ou como a organização define seus objetivos) e motivadores dos funcionários (ou como a organização motiva os funcionários). A dimensão de meios consiste na coordenação de atividades (ou como a organização coordena (e controla) suas atividades) e tomada de decisões (Como a organização toma decisões). O tipo de direcionamento e intensidade entre cada uma dessas dimensões define um tipo distinto de modelo de operações. Por exemplo, o autor sugere que empresas startups possuem o perfil denominado descoberta tal como ilustrado na figura 54. 


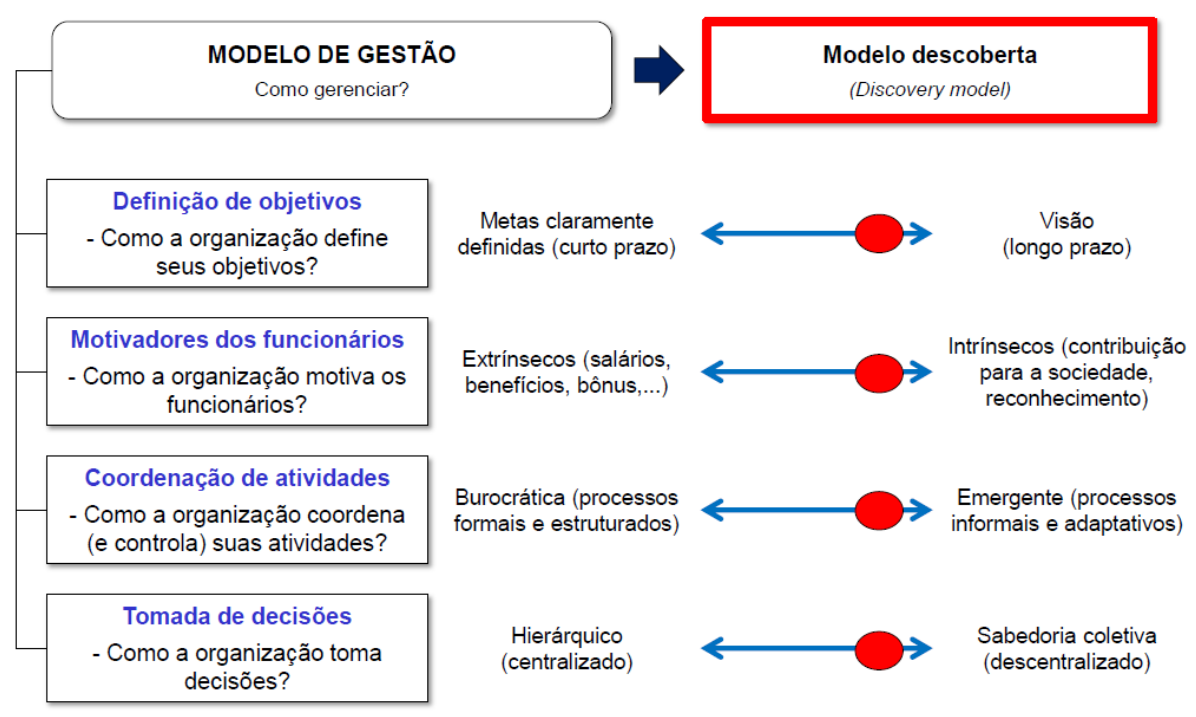

Figura 54. Representação do modelo de gestão do tipo descoberta (Fonte: Pedroso, 2018).

A figura 55 ilustra a tipologia de modelos de inovação utilizado no processo utilizado nesse estudo tal como descrito por Pedroso, 2018.

\begin{tabular}{|c|c|l|}
\hline $\begin{array}{c}\text { TIPOLOGIA DE } \\
\text { MODELO DE GESTÃo }\end{array}$ & SUBMODELO & \multicolumn{1}{c|}{ DEFINIÇÃo } \\
\hline MODELO PLANEJAMENTO & Modelo planejamento & define os fins e meios \\
\hline MODELO INDAGATIVO & Modelo indagativo & define os fins, descentraliza os meios \\
\hline MODELO CIENTÍFICO & Modelo científico & controla os meios, descentraliza os fins \\
\hline MODELO DESCOBERTA & Modelo descoberta & descentraliza os fins e os meios \\
\hline
\end{tabular}

Figura 55. Tipologia do Modelo de Gestão (Fonte: adaptado de Pedroso, 2018).

A pesquisadora define o modelo de gestão da Sampa Tech de forma distinta do sugerido pelo autor. Nessa startup a definição de objetivos definem não somente visão de longo prazo mas também metas de curto prazo para efetivação da visão. Ainda, a tomada de decisão é centralizada nos fundadores. Dessa forma, os fins e meios são moderadamente definidos.

O resultado do processo juntamente com a reflexão da pesquisadora no decorrer da etapa 16 do processo é resumido na figura 56. 


\begin{tabular}{|c|c|c|}
\hline QUESTão & RESPOSTA AO PROCESSO & \multirow{2}{*}{ REFLEXão DA PESQUISADORA } \\
\hline Como a organização define seus objetivos? & visão de longo prazo e metas de curto prazo & \\
\hline Como a organização motiva seus funcionários? & Intríseco \\
\hline Como a organização coordena suas atividades? & Forma emergente & \\
\hline Como a organização toma decisões? & centralizada nos fundadores & \\
\hline $\begin{array}{c}\text { Qual é a estratégia de integração ou separação da } \\
\text { unidade de negócios? }\end{array}$ & NA & \\
\hline Qual é formato jurídico da nova empresa? & Já estabelecido & \\
\hline
\end{tabular}

Figura 56. Quadro ilustrativo que resume os resultados da etapa 16 do ciclo 4 (Fonte: adaptado de Pedroso, 2018).

\subsubsection{Etapa $17 \quad$ Modelo de Negócios (Inicial)}

A pesquisadora considerou que essa etapa não agregava informações relevantes ao processo, e portanto, a etapa não gerou resultados.

\subsubsection{Etapas 18 e 19 Estrutura de Custos (calculada) e Geração de Valor}

Nessa etapa é realizada a categorização dos custos de acordo com os modelos para auxiliar na gestão e alteração do modelo de negócios caso seja recomendado.

Os custos de produtos vendidos ou serviços são associados com modelo de operações, os custos de pesquisa-desenvolvimento são associados com modelo de inovação, os custos de marketing/vendas são associados com modelo de relacionamento com clientes, os custos de despesas administrativas, despesas gerais e impostos são associados com modelo de gestão.

A pesquisadora observa que a Sampa Tech possui como mais proeminentes com relação ao custo, o modelo de operações e o modelo de inovação. A pesquisadora acredita que esse tipo de reflexão é pertinente para a gestão e execução do modelo de negócios.

O resultado do processo juntamente com a reflexão da pesquisadora no decorrer das etapas 18 e 19 do processo é resumido na Figura 57.

\begin{tabular}{|c|c|c|}
\hline QUESTÃo & RESPOSTA AO PROCESSO & REFLEXÃo DA PESQUISADORA \\
\cline { 1 - 2 } Qual é a estimativa(final) da estrutura de custos? & positiva & $\begin{array}{c}\text { Os questionamentos são relevantes para a } \\
\text { definição da viabilidade econômica do projeto. }\end{array}$ \\
\hline Qual é a estimativa(final) do capital a ser investido? & positiva & positivo \\
\hline Qual é o valor gerado pelo modelo de negócios? & y & \\
\hline
\end{tabular}

Figura 57. Quadro ilustrativo que resume os resultados das etapas 18 e 19 do ciclo 4 (Fonte: adaptado de Pedroso, 2018). 
6.4.11 Etapa $20 \quad$ Validação do Modelo de negócios

A pesquisadora considerou que essa etapa não agregava informações relevantes ao processo, e portanto, a etapa não gerou resultados. O modelo de negócios nessa etapa já encontra-se validado pelas validações no decorrer do processo.

\subsubsection{Etapa $21 \quad$ Modelo de negócios (final)}

Nessa etapa a pesquisadora reuniu de forma sintética as informações adquiridas durante o processo, e representou o modelo de negócios de acordo com estrutura definida por (Pedroso, 2017) tal como ilustrado na Figura 58. 


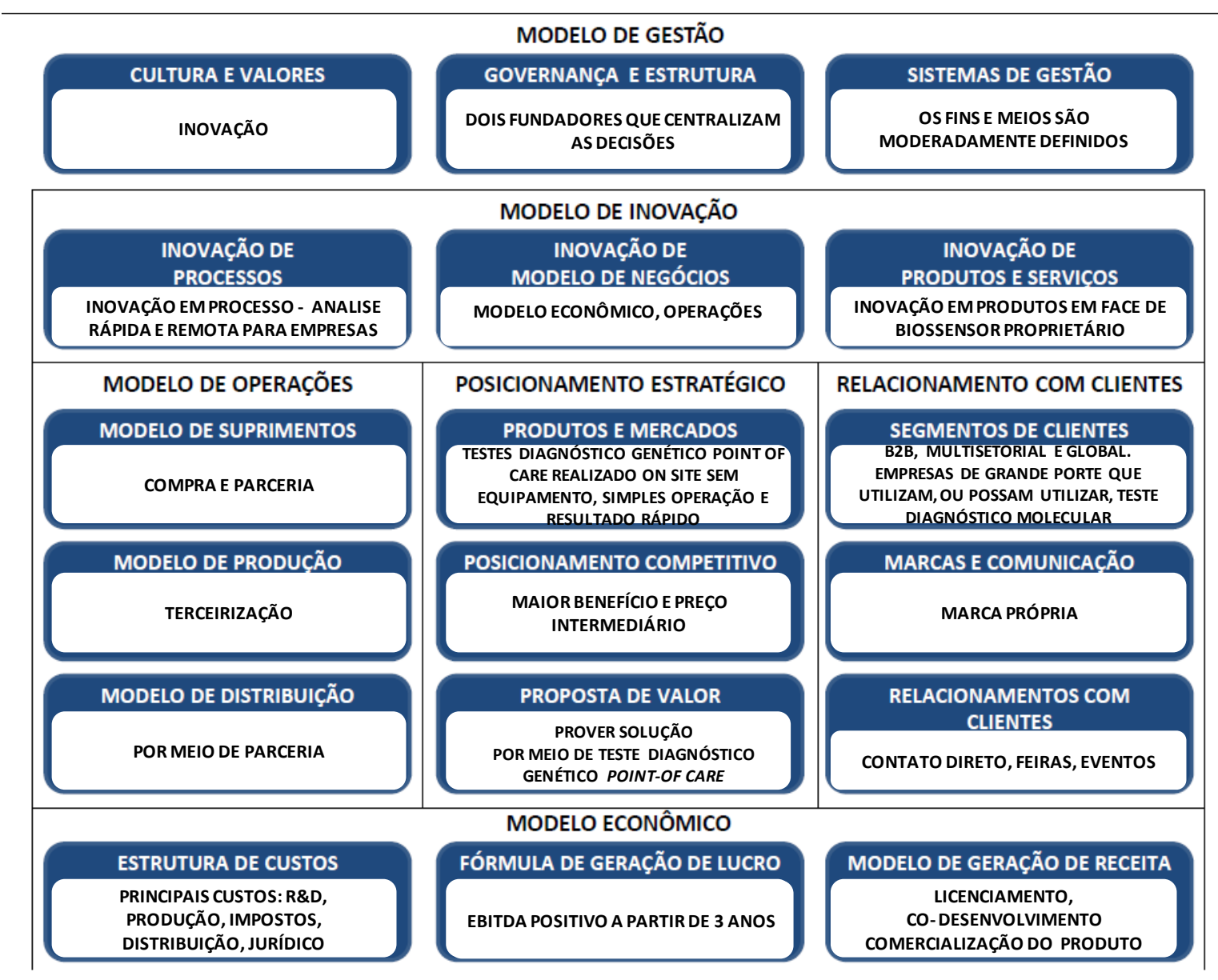

Figura 58. Esquematização do modelo de negócios da Sampa Tech (Fonte: adaptado de Pedroso, 2017). 


\section{DISCUSSÃO}

Um dos métodos descritos na literatura para a construção de um negócio sustentável baseado em inovação define como objetivo o teste de hipóteses e aprendizado sobre os possíveis clientes, e não completar cada etapa com 100\% de precisão (Aulet, 2013). Tal definição foi considerada como premissa pela pesquisadora quando pesquisou, selecionou, testou e analisou o método de construção de modelo de negócios no presente trabalho avaliação e escolha de hipóteses e investigação que subsidiem o modelo de negócios por meio de um processo estruturado adequado para startup em biotecnologia.

O desenvolvimento da biotecnologia possui uma alta dependência da pesquisa básica em biologia molecular havendo uma conexão estreita entre a pesquisa científica básica e a biotecnologia comercial (Bartholomew, 1997). De fato, startups em biotecnologia são fundamentadas primordialmente em inovação, ou seja, produtos e/ou serviços inovadores.

A pesquisadora analisou 6 métodos de construção de modelos de negócios aplicáveis em startups fundamentadas em inovação. Vale ressaltar que esses métodos podem ser classificados em: (i) métodos de construção de modelo de negócios inseridos em metodologia de constituição de startups (Blank \& Dorf, 2012 e Aulet, 2013), (2) métodos de construção de modelo de negócios per se (Osterwalder \& Pigneur, 2010; Gassmann et al., 2014; e Pedroso, 2018); e (3) métodos de construção de modelo de negócios inseridos em metodologia de criação, refinamento e lançamento de ideias de um novo produto no mercado (Furr \& Dyer, 2014).

Uma análise comparativa entre os métodos de construção de modelo de negócios mostra que há similaridades em seus elementos e etapas tal como descrito no Capítulo 4 e ilustrado na figura 9.

O método descrito por Pedroso, 2018 foi selecionado pela pesquisadora para a pesquisa ação em uma startup brasileira de biotecnologia, a Sampa Tech.. Esse método é composto por 21 etapas que foram inicialmente agrupadas em 3 ciclos planejados que correspondem a validação do problema, validação da solução e validação do modelo de negócios em .

A pesquisadora selecionou esse método visto que o mesmo se fundamenta em uma metodologia aplicável a empreendimentos derivados de inovação (IDE), ser orientado 
especificamente para a construção de modelo de negócios, e que contempla uma inovadora arquitetura de modelo de negócios em uma página descrita por Pedroso, 2016 (que apresenta duas dimensões adicionais: modelo de gestão e modelo de inovação).

O presente estudo consistiu de 4 ciclos realizados de pesquisa ação como discutido a seguir.

7.1 Ciclo 1: $\quad$ Validação do problema

A literatura versa que um novo empreendimento pode ser iniciado por uma das três razões: uma ideia, uma paixão ou um avanço tecnológico (Aulet, 2013).

O método definido por Pedroso, 2018 segue esse princípio e inicia com a etapa de descoberta (1) que por sua vez vislumbra que o processo de identificação de oportunidades ocorre por meio da convergência das perspectivas do empreendedor influenciadas pelo panorama que -o cerca - ecossistema e megatendências. Essa etapa possui como objetivo alinhar as competências dos empreendedores, ecossistema e megatendências que devem ser a fundamentação do novo empreendimento, e modelo de negócios, a ser concebido.

A pesquisadora seguiu tal alinhamento de forma sequencial tal como descrito no Capítulo 6 e obteve sucesso na definição do insight a fundamentar a empresa. Em confronto com a teoria acerca do tema, a pesquisadora constatou que essa etapa compartilha elementos com etapas similares presentes em outros métodos de construção de modelo de negócios e/ou startups, tais como a etapa denominada de insights, nos métodos descritos por Osterwalder \& Pigneur, 2010 e Furr \& Dyer, 2014. No método descrito por Aulet, 2013 essa etapa possui um paralelo na etapa 0 em que as ideias ou propostas são listadas anteriormente ao início do método. Nos métodos descritos por Blank \& Dorf, 2012 e Gassmann et al., 2014 não há referência para constituição de ideias. Esses métodos preveem que as ideias já são conhecidas.

Pelo acima exposto a pesquisadora acredita que a etapa de insight seja relevante para o processo de construção de modelo de negócios em uma startup de biotecnologia, tal como ocorreu com a Sampa Tech. Contudo, possivelmente essa etapa não seja essencial para toda startup nesse segmento visto que muitas das ideias nesse segmento são oriundas de pesquisas científicas pontuais que apresentam resultados proeminentes e atraentes para serem aplicados como inovações tecnológicas. 
A pesquisadora esclarece que no caso da Sampa Tech não foi necessário definir o contexto externo como sugerido na etapa 1 do método aplicado . Todavia, foi realizado o mapeamento de tecnologia, ou seja, uma investigação acerca das tecnologias existentes no mercado por meio de pesquisa de mercado, literatura científica e documentos de patente. Esse procedimento foi relevante para a Sampa Tech, e parece ser aplicável para tornar a etapa 1 ainda mais eficaz para startups fundamentadas em inovação e novas tecnologias.

A pesquisadora observou por meio de vivência no Curso MIT's Entrepreneurship Bootcamp (Online): From Idea to Startup in Eight Weeks promovido pelo Massachusetts Institute of Technology (MIT) coordenado por Bill Aulet, ser particularmente difícil avaliar oportunidades sem antes, ou concomitantemente, refletir sobre o mercado. Nota-se que durante o curso a pesquisadora avaliou o processo para a constituição de uma startup do segmento de tecnologia da informação, e não biotecnologia. No decorrer da etapa 1 do método de construção de modelo de negócios descrito por Pedroso, 2018, a pesquisadora não sentiu essa dificuldade. Em reflexão sobre o processo, a pesquisadora conclui que o mesmo deve ser devido ao desenho de macrotendências realizado na etapa 1 onde fornece informações sobre o mercado de forma abrangente. Assim, a pesquisadora considera essa análise de grande relevência para construção de modelo de negócios em startups de biotecnologia.

Em confrontação da prática com a teoria, a pesquisadora identificou na literatura, e considerou como extremamente útil e relevante, a etapa de ideação presente no método descrito por Osterwalder \& Pigneur, 2010, que por sua vez é correspondente aos estágios de segmentação de mercado e mercado beachhead descritos em Aulet, 2013. Esses elementos se mostram úteis na forma de reflexão do tipo brainstorm sobre possíveis clientes para a ideia, ou inovação em biotecnologia, e classificação e seleção de clientes alvo.

Essa etapa faz-se relevante para construção de modelo de negócios em biotecnologia uma vez que não é incomum que a mesma tecnologia/inovação em biotecnologia possa assumir distintas aplicações e atingir diferentes segmentos de clientes. Ainda, esse tipo de levantamento mostra-se extremamente relevante para vislumbrar clientes não óbvios, planejar o produto (em fase posterior), e responder ao mercado de forma mais rápida (ex. em caso de alteração do produto por resultados técnicos imprevisíveis que são intrínsecos da atividade de $\mathrm{P} \& \mathrm{D}$ em biotecnologia - que são possíveis de acontecer no decorrer do longo desenvolvimento da tecnologia e/ou do produto). 
Ainda, a pesquisadora identificou que no método definido por Aulet, 2013 é na etapa posterior à segmentação de mercado que ocorre a seleção do mercado inicial para atuação dominante - denominado de beachhead. Essa etapa ocorre de acordo com a definição de possíveis clientes para a ideia/tecnologia/inovação em biotecnologia. A definição do mercado beachhead seria muito eficaz para a determinação do foco em um mercado inicial (e posterior proposta de valor) no segmento de biotecnologia. Além disso, contribuiria para a manutenção da startup fluida ("não engessada"), e capaz de responder rapidamente a possíveis modificações técnicas do produto ou do mercado.

A pesquisadora revela que em momento anterior a intervenção na Sampa Tech, realizou a etapa de ideação descrita nesse método. Essa ferramenta forneceu resultados eficazes na seleção de possíveis clientes e mercados alvo, o que ainda propiciou a resposta rápida ao mercado.

Assim, a pesquisadora sugere que as etapas de ideação sejam consideradas na etapa 1 do método de construção de modelo de negócios descrito por Pedroso, 2018 - quando aplicado a empreendimento startup no segmento de biotecnologia.

Outro aspecto relevante a ser abordado com relação a etapa 1 do método de construção de modelo de negócios descrito por Pedroso, 2018 é a utilização da cadeia de valor para análise da oportunidade. A pesquisadora entende que o conceito de exploração de possíveis pontos na cadeia de valor onde possa ser identificado um problema (oportunidade) é relevante, e pode ser de fato utilizado para empreendimentos em biotecnologia.

Contudo, vale ressaltar que não há uma cadeia de valor única para biotecnologia. A mesma é dependente do tipo de produto, tecnologia e segmento a que se aplica. Por essa razão no caso da Sampa Tech a cadeia de valor não foi aplicável visto que a ideia/inovação/tecnologia refere-se a diferentes produtos associados a distintas cadeias de valor.

Assim, a pesquisadora conclui que a cadeia de valor não necessariamente é cabível na construção de modelo de negócios em biotecnologia visto que esse segmento abrange mercados distintos, e clientes diversificados em cada um desses mercados. A ideia/inovação/tecnologia pode ser, em alguns casos, tal como ocorreu com a Sampa Tech, aplicada em vários mercados e associados a clientes presentes em cadeias de valor muitos 
distintas. Nesse caso, haveria de se analisar não somente uma, mas várias cadeias de valor o que pode ser considerada inviável.

A pesquisadora conclui que as oportunidades no caso de startups em biotecnologia seriam melhor identificadas por uma etapa de ideação que consideraria as possíveis aplicações ou utilizações da ideia/tecnologia/inovação.

A pesquisadora cumpriu a etapa 2 método de construção de modelo de negócios descrito por Pedroso, 2018 onde concluiu que o cálculo do tamanho de mercado em 4 níveis foi apropriado e eficiente no processo, sendo utilizado como balizador para a existência de mercado atrativo para o produto. No decorrer do processo a pesquisadora achou interessante adicionar a essa etapa do método a questão inicial "se o mercado é global ou territorial". A mesma serviria como uma provocação para a reflexão da startup quanto ao potencial de alcance global da ideia/tecnologia/inovação que além de ser atrativo com relação a tamanho de mercado pode refletir na seleção dos clientes e posteriormente no desenvolvimento do produto.

Nas etapas 3 (segmento de clientes) e 4 (definição do problema) a pesquisadora vivenciou dificuldade na reflexão e definição do segmento de cliente alvo e problema, sem antes considerar a definição da solução e posicionamento competitivo, que compõem as etapas posteriores de resolução do problema e posicionamento. A pesquisadora acredita que tal dificuldade seja reflexo do tipo de oportunidade da Sampa Tech que é per se uma solução.

É relatado na literatura o conceito de que a inovação deriva por demanda do mercado ou pelo impulsionamento por uma nova tecnologia, assumindo a denominação de inovação de rota mercadológica (demand-driven) ou rota tecnológica (technology-push), respectivamente.

A pesquisadora identifica que o método de construção de modelo de negócios descrito por Pedroso, 2018 se propõe a ser aplicado ao tipo de inovação de rota mercadológica, uma vez que observa que nesse método a definição do modelo de negócios segue a lógica "problema-solução-modelo de negócio" disposto em etapas agrupadas em ciclo 1 (validação do problema), ciclo 2 (validação da solução) e ciclo 3 (validação do modelo de negócios) tal como ilustrados nas figuras 6 e 7 , respectivamente.

Contudo, a pesquisadora observa a intenção do autor em aplicar o método de construção de modelo de negócios também em empreendimentos que se fundamentam em 
inovação do tipo rota tecnológica em face de contemplar adicionalmente a possibilidade de direção inversa sendo solução-problema-modelo de negócios como mostrado na figura 6.

Portanto, a pesquisadora sugere a adoção de um ordenamento alternativo das etapas do método de construção de modelo de negócios descrito por Pedroso, 2018 para de fato contemplar ideias/tecnologia/inovação de rota tecnológica para a efetiva aplicação em startups de hard science ou biotecnologia.

Ainda, a pesquisadora sugere que uma alternativa para aplicação mais eficaz do método de construção de modelo de negócios descrito por Pedroso, 2018 em startups de rota tecnológica seria a adição de uma etapa de ideação como etapa 2 do método. Nessa etapa a solução seria confrontada de forma direta com os problemas de clientes alvo por meio da atividade de brainstorm. O mesmo agregaria fluidez para a validação do problema que é o objetivo do ciclo 1. Os resultados dessa etapa podem ser adicionalmente utilizados para a confrontação com os resultados da matriz de avaliação de valor e do canvas da proposta de valor auxiliando na definição da proposta de valor presentes na etapa 7 do ciclo 2 .

No cumprimento da etapa 4 do método de construção de modelo de negócios descrito por Pedroso, 2018, a pesquisadora concluiu que a matriz de importância-desempenho não agregaria informações relevantes para a definição do problema, e assim não a utilizou. Entretanto, a enumeração dos atributos competitivos foi bastante relevante no processo.

\subsection{Ciclo 2: $\quad$ Validação da solução}

A pesquisadora observou no decorrer da etapa 7 que a matriz de avaliação de valor da Sampa Tech foi extremamente relevante para a definição da proposta de valor. Essa matriz foi eficaz na definição de forma estruturada e assertiva dos atributos competitivos da ideia/tecnologia/inovação. Esse fato também foi observado nas mentorias realizadas pela pesquisadora em auxílio a startups de base científica em biotecnologia que por sua vez não seguia o método de construção de modelo de negócios descrito por Pedroso, 2018, mas que pela sugestão da pesquisadora utilizaram a matriz de avaliação de valor para auxílio na definição da proposta de valor. Os mentorados conseguiriam visualizar de forma mais eficiente os atributos competitivos de forma a dicerni-los das vantagens meramente científicas e técnicas. Houve uma reflexão de fato no produto e não na tecnologia per se.A pesquisadora acrescenta que essa matriz também auxiliaria na definição do mercado. 
Assim, a pesquisadora conclui que a realização da matriz de avaliação de valor é essencial para a definição da proposta de valor, e no método de construção de modelo de negócios em startups de biotecnologia.

A pesquisadora concluiu que a etapa 8 do método de construção de modelo de negócios descrito por Pedroso, 2018 foi útil para a visualização do mercado e validação do preço apesar de que as soluções consideradas no caso da Sampa Tech não eram soluções substituintes e sim alternativas. Ainda, a adoção do mapa de posicionamento competitivo seguindo o modelo de Porter foi interessante para a confirmação da precificação da solução ofertada pela Sampa Tech.

No final da etapa 10 do método de construção de modelo de negócios descrito por Pedroso, 2018, a pesquisadora concluiu que a visualização do canvas de validação da proposta de valor foi relevante para a validação da solução uma vez que foi uma ferramenta visual para avaliação de vários aspectos associados à solução de forma integrada.

A literatura aponta que cenários de modelo de negócios alternativos podem emergir por meio da análise de: diferencial técnico, da monetização e potencial de mercado do portfólio atual e pipeline. Assegurar a propriedade intelectual a tecnologias é uma maneira frequente de alcançar tais objetivos (Tsai \& Erickson, 2006).

A pesquisadora obervou que o método de método de construção de modelo de negócios descrito por Pedroso, 2018 não considera a propriedade intelectual como ponto a ser explorado. Entretanto, a pesquisadora identificou que o método descrito por Aulet, 2013 possui o estágio 11 (definição do core) que aborda a propriedade intelectual como um fator importante para que a startup entregue valor com maior eficiência que o concorrente. $\mathrm{O}$ autor afirma que tal análise tem como objetivo identificar competências da startup que dificulte o competidor seguir a mesma proposta. Essas competências incluemrede de relacionamento, menor custo e propriedade intelectual.

A pesquisadora entende que a abordagem de definição do core da startup deveria ser considerada no método de construção de modelo de negócios em startups de biotecnologia.

\section{3. $\quad$ Ciclo 3: $\quad$ Pivotagem}


O método de construção de modelo de negócios descrito por Pedroso, 2018 é fundamentado na arquitetura de modelo de negócios em uma página desenvolvido por Pedroso, 2016. Essa arquitetura denomina os componentes constituintes do modelo de negócios como: modelo de gestão (como organizar), modelo de inovação (como mudar), modelo de operações (como entregar), posicionamento estratégico (o que entregar), modelo de relacionamento com cliente (para quem entregar), e modelo econômico (como criar e capturar valor).

O ciclo 3 foi planejado pela Pesquisadora para desenvolver e definir os referidos componentes do modelo de negócios da Sampa Tech. Contudo, o mesmo foi interrompido na etapa fórmula de lucro (12) visto que a mesma não resultou em conclusões satisfatórias para o modelo de negócios. Dessa forma, a Pesquisadora elaborou um novo ciclo denominado de 4 tal como tal como descrito na Figura 59.

7.3. Ciclo 3: $\quad$ Validação do modelo de negócios

O ciclo 4 realizado da pesquisa ação consistiu das etapas de: Segmento de clientes (3), Proposta de valor (7), Modelo de geração de receita (9), Estrutura de custos (11), Fórmula de lucro (12), Modelo de operações (13), Modelo de relacionamento com clientes (14), Modelo de Inovação (15), Modelo de gestão (16), Modelo de Negócios Inicial (17), Estrutura de custos calculada (18) e Geração de valor (19) (Figura 59). 


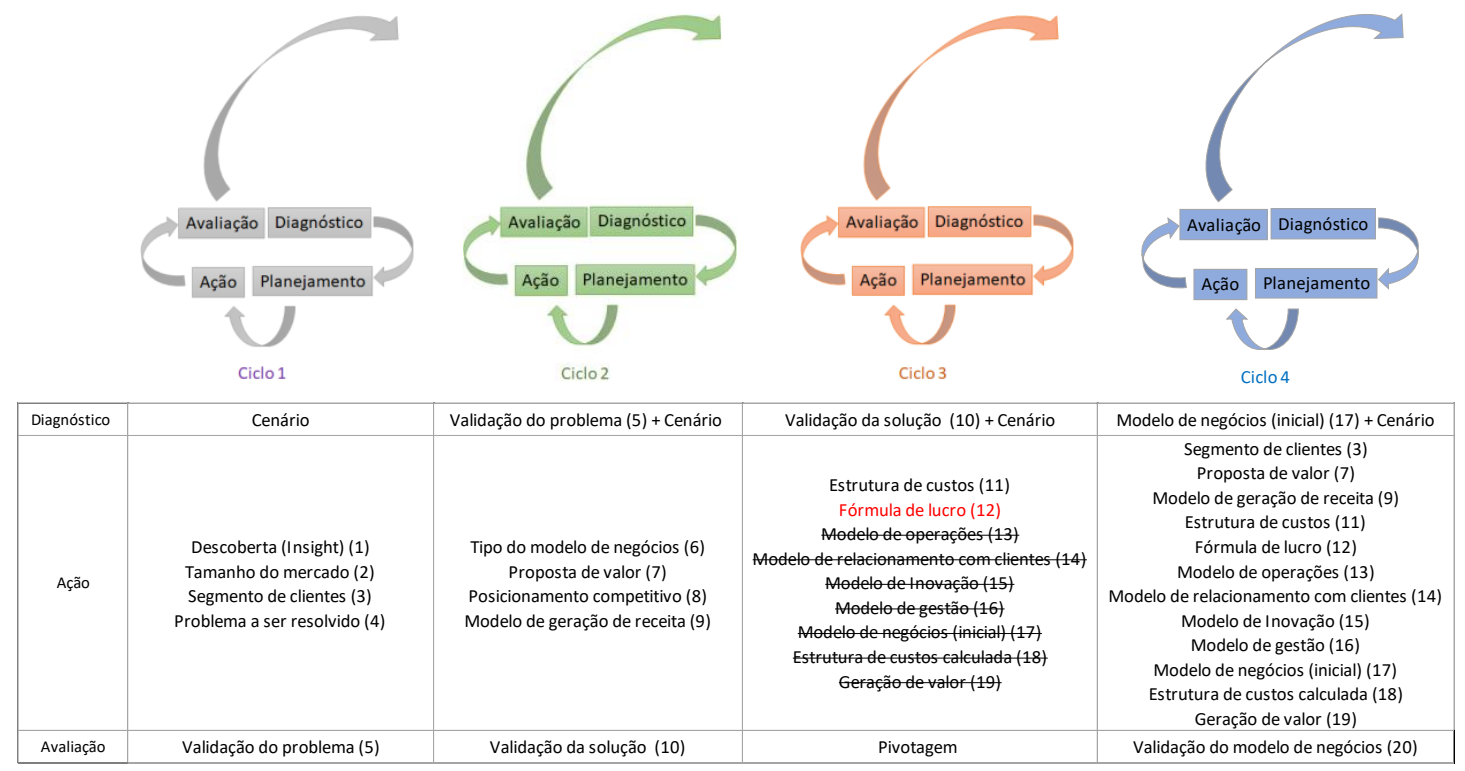

Figura 59: Ciclos realizados de pesquisa ação (Fonte: a autora).

Nas etapas que constituem o ciclo 4 do método de construção de modelo de negócios, particularmente as etapas 13,14, 15 e 16, os componentes do modelo de negócios são avaliados individualmente a partir do posicionamento estratégico definido no ciclo 2 . A análise ocorre com relação ao modelo de operações, modelo de relacionamento com clientes, modelo de inovação e modelo de gestão, respectivamente. O modelo econômico é definido em decorrência das etapas 11, 12, 18 e 19.

A análise no ciclo 4 ocorreu por meio de reflexão estruturada sobre os aspectos intrínsecos da startup que ocorre primordialmente por meio de um processo simplificado comparativo para a seleção de tipologias dentro de um grupo previamente descrito por Gassmann et al., 2014. A tipologia consiste em tipos e subtipos de modelo de negócios e fundamenta-se na ideia central de que os modelos de negócio bem-sucedidos podem ser construídos por meio da imitação criativa e da recombinação.

A pesquisadora conclui que tal abordagem é conveniente e auxilia na definição dos componentes do modelo de negócios. Ainda, a pesquisadora observa que não há na tipologia descrita por Gassmann et al., 2014 que seja associada especificamente a empreendimentos em biotecnologia. Seria relevante e útil se houvesse também uma tipologia de modelo de negócios em biotecnologia visto que empreendimentos nesse segmento possuem algumas particularidades que podem refletir de forma particular nos componentes do modelo de negócios. 
Vale ressaltar que uma mesma ideia/produto/tecnologia da biotecnologia pode possuir aplicação comercial em produtos e processos em uma ampla variedade de clientes em setores industriais distintos inclusive, tal como ocorre com Sampa Tech. De fato, esse evento pode justificar o cenário mostrado pelas maiores empresas de biotecnologia que geraram receita por meio da implantação de modelos de negócios simultâneos relacionados a clientes distintos (Sabatier, Mangematin\& Rousselle, 2010).

A pesquisadora identificou na literatura a citação de tipologias de modelo de negócios em empresas de biotecnologia tal como resumido na figura 57. Por meio da análise desse levantamento a pesquisadora concluiu que os modelos de negócio em biotecnologia priorizam o modelo de operações e modelo econômico. Esse fato deve ocorrer provavelmente por essas startups priorizarem na sua sustentabilidade.

Corrobora-se com esse achado o fato da estratégia de financiamento ser frequentemente o maior foco da startup em biotecnologia em face do longo desenvolvimento do produto e consequente retardamento do início da geração de receita, que é intrínseco dessa indústria. O financiamento é necessário para gerar ganhos para operações, e assim direcionar o desenvolvimento do produto e estratégias de negócio. De fato, iniciar e sustentar uma startup fundamentada em $\mathrm{P} \& \mathrm{D}$, particularmente no setor de biotecnologia, requer um modelo de negócios que aperfeiçoe estratégias de financiamento, mercado e operacional (Tsai \& Erickson, 2006).

A literatura mostra que algumas startups em biotecnologia adotam um portfólio diversificado de modelos de negócios visando maximizar a captação de valor do seu know how e das suas atividades associadas à $\mathrm{P} \& \mathrm{D}$. $\mathrm{O}$ equilíbrio entre os modelos de negócio é determinante para a geração de receita a curto e médio prazo, para subsidiar o longo prazo intrínseco ao desenvolvimento do negócio derivado de P\&D em biotecnologia. Assim tentase equilibrar as incertezas e o longo período entre o investimento e a obtenção de receita que são típicos do setor de biotecnologia (Sabatier, Mangematin \& Rousselle, 2010).

Face ao acima exposto, a pesquisadora conclui que seria de grande valia a utilização de tipologia de modelo de negócios específica para startups do segmento de biotecnologia.

A pesquisadora observou que a avaliação financeira da startup é extensamente avaliada no ciclo 3 do método descrito por Pedroso, 2018, particularmente nas etapas 11, 12, 18 e 19 para a construção e validação do modelo de negócios. De fato, na etapa 18 foi 
realizada a demonstração do resultado do exercício (DRE) estimado da startup em face de premissas previamente assumidas.

Adicionalmente, a pesquisadora obervou que no método descrito por Pedroso, 2018 considera-se um empreendimento promissor quando a relação de LTV:COCA é maior que 3. No entanto, a pesquisadora ressalta já esperava que no caso da Sampa Tech essa relação fosse maior que 3, visto que é B2B e o produto possui alto valor agregado. Assim, a pesquisadora acredita que esse cálculo não é relevante para startups em biotecnologia do perfil da Sampa Tech.

Os outros métodos de construção de modelo de negócios analisados nesse trabalho não exploram de forma minuciosa o modelo econômico. Particularmente o método descrito por Aulet, 2013 somente analisa o valor do ciclo de vida do cliente (LTV) e o custo de aquisição do cliente (COCA), e em momento posterior a construção do modelo de negócios. A pesquisadora aponta que o LTV deve ser calculado com relação a custo de produção somente, não incluindo despesas de $\mathrm{P} \& \mathrm{D}$, e outros. O posicionamento desse autor poderia conduzir para a conclusão de que o método de construção de modelo de negócios em biotecnologia não deveria considerar o modelo econômico em detalhes por não ser relevante.

Contudo, visto que como anteriormente descrito o modelo econômico é de grande relevância para empresas de biotecnologia, e despesas de P\&D são um ponto importante nesse cenário, a pesquisadora conclui que a abordagem de análise criteriosa e detalhada do modelo econômico como sugerido por Pedroso, 2018 é de grande relevância para startups em biotecnologia.

Ainda, a pesquisadora possui conhecimento por meio de vivência prática que o acesso ao capital de risco para investimento em startup é restrito no Brasil e praticamente inexistente para inovação em biotecnologia. Assim, a ausência de recursos financeiros podem ser impeditivos para a execução de uma startup de biotecnologia sustentável. Assim, a pesquisadora conclui que o modelo econômico é relevante para a construção de modelo de negócios em startup em biotecnologia no Brasil.

Os resultados podem ser visualizados de forma resumida na Figura 60. 


\begin{tabular}{|c|c|c|c|c|c|c|}
\hline \multicolumn{2}{|c|}{ OBJETIVOS } & \multirow{2}{*}{\multicolumn{2}{|c|}{ REVISÃO BIBLIOGRÁFICA }} & \multirow{3}{*}{ PESQUISA DE CAMPO } & \multirow{2}{*}{\multicolumn{2}{|c|}{ RESULTADOS }} \\
\hline Objetivo Principal & Objetivos Específicos & & & & & \\
\hline \multirow{3}{*}{$\begin{array}{c}\text { Como desenvolver } \\
\text { o modelo de } \\
\text { negócios de uma } \\
\text { startup de } \\
\text { biotecnologia de } \\
\text { diagnóstico } \\
\text { molecular no } \\
\text { mercado } \\
\text { brasileiro? }\end{array}$} & $\begin{array}{l}\text { Identificação de } \\
\text { métodos para a } \\
\text { construção de modelos } \\
\text { de negócios em } \\
\text { empresa startup de } \\
\text { biotecnologia. }\end{array}$ & $\begin{array}{l}\text { Revisão } \\
\text { sistemática: } \\
\text { modelo de } \\
\text { negócios + } \\
\text { biotecnologia }\end{array}$ & $\begin{array}{c}\text { Revisão não } \\
\text { estruturada: } \\
\text { método de construção } \\
\text { modelo de negócios + } \\
\text { startup }\end{array}$ & & $\begin{array}{c}\text { Componentes: } \\
\text { Tölle \& Kappfjell Herbst, } 2016 \\
\text { Sabatier, Mangematin\& Rousselle, } 2010 \\
\text { Tsai \& Erickson, } 2006 \\
\text { Fisken \& Rutherford, 2002 } \\
\text { Nosella, Petroni \& Verbano, } 2006\end{array}$ & $\begin{array}{l}\text { Método de construção: } \\
\text { Osterwalder \& Pigneur, } 2010 \\
\text { Blank \& Dorf, 2012 } \\
\text { Aulet, 2013 } \\
\text { Gassmann et al., 2014 } \\
\text { Furr e Dyer, 2014 } \\
\text { Pedroso, 2018 }\end{array}$ \\
\hline & $\begin{array}{l}\text { Seleção de um método } \\
\text { para a construção de } \\
\text { modelo de negócios } \\
\text { para a intervenção em } \\
\text { uma empresa startup de } \\
\text { biotecnologia de } \\
\text { diagnóstico molecular } \\
\text { no mercado brasileiro. }\end{array}$ & & & $\begin{array}{l}\text { Pesquisa-ação 1: } \\
\text { Contexto/Proposta } \\
\text { Selecionar um método } \\
\text { estruturado para a } \\
\text { construção de modelo de } \\
\text { negócios em formato de } \\
\text { jornada. }\end{array}$ & \multicolumn{2}{|c|}{$\begin{array}{c}\text { Método selecionado de Pedroso, } 2018 \text { por ser um método estruturado } \\
\text { específico para a construção de modelo de negócios em formato de } \\
\text { jornada, e ainda possuir componentes adicionais na arquitetura de } \\
\text { modelo de negócios. }\end{array}$} \\
\hline & $\begin{array}{c}\text { Aplicação de um } \\
\text { método para a } \\
\text { construção de modelo } \\
\text { de negócios para a } \\
\text { intervenção em uma } \\
\text { empresa startup de } \\
\text { biotecnologia de } \\
\text { diagnóstico molecular } \\
\text { no mercado brasileiro. }\end{array}$ & & & $\begin{array}{c}\text { Pesquisa-ação 2: } \\
\text { Ciclos Interativos } \\
\text { Planejamento, Ação, } \\
\text { Avaliação e Diagnóstico } \\
\text { do método em ciclos } \\
\text { planejados de acordo com } \\
\text { o método. }\end{array}$ & \multicolumn{2}{|c|}{$\begin{array}{l}\text { Ciclos planejados: } 1,2 \text { e } 3 \text { de acordo com ciclos de aplicação do } \\
\text { método de Pedroso, } 2018 \text {. } \\
\text { Ciclos realizados: 1, 2, } 3 \text { e } 4 \text { por ter ocorrido pivotagem (etapa 12) no } \\
\text { decorrer do processo. }\end{array}$} \\
\hline
\end{tabular}

Figura 60: Resultados resumidos do trabalho (Fonte: a autora).

A pesquisadora conclui que o método de construção de modelo de negócios descrito por Pedroso, 2018 é efetivo para testar hipóteses de forma estruturada e geração de modelo de negócios em startups no segmento de biotecnologia. 


\section{CONCLUSÕES}

O objetivo principal desse trabalho era desenvolver o modelo de negócios de uma startup de biotecnologia de diagnóstico molecular no mercado brasileiro.

A autora entende, pela exposição dos resultados da pesquisa ação tratado neste trabalho, que esse objetivo foi cumprido com a obtenção dos resultados apresentados no Capítulo 6 e discutidos no Capítulo 7.

O primeiro objetivo específico definido pela identificação de métodos para a construção de modelos de negócios em empresa startup de biotecnologia foi cumprido por meio de revisão bibliográfica. A pesquisadora ressalta que: (i) foram identificadas 5 referências bibliográficas que discutem componentes e tipologia de modelo de negócios em biotecnologia, e (ii) foram identificados 6 métodos para a construção de modelos de negócios em startup.

O segundo objetivo específico definido pela seleção de um método para a construção de modelo de negócios para a intervenção em uma empresa startup de biotecnologia de diagnóstico molecular no mercado brasileiro foi cumprido por meio da pesquisa ação. A pesquisadora ressalta que: (i) foi selecionado o método de Pedroso, 2018 para a construção de modelos de negócios em uma startup de biotecnologia no mercado brasileiro, a Sampa Tech, e (ii) a seleção desse método ocorreu visto que o mesmo possui as características: é um método estruturado em formato de jornada, e ainda possui componentes adicionais na arquitetura de modelo de negócios.

O terceiro objetivo específico definido pela aplicação de um método para a construção de modelo de negócios para a intervenção em uma empresa startup de biotecnologia de diagnóstico molecular no mercado brasileiro foi cumprido por meio da pesquisa ação. A pesquisadora ressalta que: (i) foram realizados os ciclos 1, 2, 3 e 4 na construção de modelos de negócios em uma startup de biotecnologia no mercado brasileiro, a Sampa Tech. Devido a pivotagem no ciclo 3 previsto na avaliação econômica, e (ii) a pesquisadora sugeriu adequações no método descrito por Pedroso, 2018 para aplicação em startups de biotecnologia.

A confrontação entre os objetivos, revisão bibliográfica, pesuisa de campo, resultados e conclusões pode ser visualizada de forma resumida na Figura 61. 


\begin{tabular}{|c|c|c|c|c|c|c|c|}
\hline \multicolumn{2}{|c|}{ OBJETIVOS } & \multirow{2}{*}{\multicolumn{2}{|c|}{ REVISÃO BIBLIOGRÁFICA }} & \multirow{3}{*}{ PESQUISA DE CAMPO } & \multirow{2}{*}{\multicolumn{2}{|c|}{ RESULTADOS }} & \multirow{2}{*}{ CONCLUSŌES } \\
\hline Objetivo Principal & Objetivos Específicos & & & & & & \\
\hline \multirow{3}{*}{$\begin{array}{l}\text { Como desenvolve } \\
\text { o modelo de } \\
\text { negócios de uma } \\
\text { startup de } \\
\text { biotecnologia de } \\
\text { diagnóstico } \\
\text { molecular no } \\
\text { mercado } \\
\text { brasileiro? }\end{array}$} & $\begin{array}{c}\text { Identificação de } \\
\text { métodos para a } \\
\text { construção de modelos } \\
\text { de negócios em } \\
\text { empresa startup de } \\
\text { biotecnologia. }\end{array}$ & $\begin{array}{l}\text { Revisão } \\
\text { sistemática: } \\
\text { modelo de } \\
\text { negócios }+ \\
\text { biotecnologia }\end{array}$ & $\begin{array}{l}\text { Revisão não } \\
\text { estruturada: } \\
\text { método de construção } \\
\text { modelo de negócios + } \\
\text { startup }\end{array}$ & & $\begin{array}{c}\text { Componentes: } \\
\text { Tölle \& Kappfjell Herbst, } 2016 \\
\text { Sabatier, Mangematin\& Rousselle, } 2010 \\
\text { Tsai \& Erickson, 2006 } \\
\text { Fisken \& Rutherford, } 2002 \\
\text { Nosella, Petroni \& Verbano, } 2006\end{array}$ & $\begin{array}{l}\text { Método de construçăo: } \\
\text { Osterwalder \& Pigneur, } 2010 \\
\text { Blank \& Dort, } 2012 \\
\text { Aulet, } 2013 \\
\text { Gassmann et al, } 2014 \\
\text { Furr e Dyer, } 2014 \\
\text { Pedroso, } 2018 \\
\end{array}$ & $\begin{array}{l}\text { - Foram identificadas } 5 \text { referências bibliográticas } \\
\text { que discutem componentes e tipologia de modelo } \\
\text { de negócios em biotecnologia. } \\
\text { "Foram identificados } 6 \text { métodos para a construçăa } \\
\text { de modelos de negócios em startup. }\end{array}$ \\
\hline & \begin{tabular}{|c|} 
Seleçăo de um método \\
para a construção de \\
modelo de negócios \\
para a intervenção em \\
uma empresa startup de \\
biotecnologia de \\
diagnóstico molecular \\
no mercado brasileiro. \\
\end{tabular} & & & $\begin{array}{l}\text { Pesquisa-açāo 1: } \\
\text { Contexto/Proposta } \\
\text { Selecionar um método } \\
\text { estruturado para a } \\
\text { constructuáo do modelo de } \\
\text { negócios em formato de } \\
\text { jornada. }\end{array}$ & \multicolumn{2}{|c|}{$\begin{array}{l}\text { Método selecionado foi o de Pedroso, } 2018 \text { por ser um método } \\
\text { estruturado especifico para a construcăo de modelo de negócios em } \\
\text { formato de jormada, e ainda possuir componentes adicionais na } \\
\text { arquitetura de modelo de negócios. }\end{array}$} & $\begin{array}{l}\text { * Foi selecionado o método de Pedroso, } 2018 \\
\text { para a construção de modelos de negócios em uma } \\
\text { startup de biotecnologia no mercado brasileiro, a } \\
\text { Sampa Tech. } \\
\text { "A seleção ocorreu por ter as caracteristicas: ser } \\
\text { um método estruturado em formato de jornada, e } \\
\text { ainda possuir componentes adicionais na arquitetura } \\
\text { de modelo de negócios. }\end{array}$ \\
\hline & \begin{tabular}{|c|} 
Aplicaçăo de um \\
método para a \\
construção de modelo \\
de negócios para a \\
intervenção em uma \\
empresa startup de \\
biotecnologia de \\
diagnóstico molecular \\
no mercado brasileiro.
\end{tabular} & & & $\begin{array}{c}\text { Pesquisa-açăo 2: } \\
\text { Cicios Interativos } \\
\text { Planejamentio, Açấo, } \\
\text { Avaliaçao o Diagnóstico } \\
\text { do método em ciclos } \\
\text { planejados de acordo com } \\
\text { o método. }\end{array}$ & \multicolumn{2}{|c|}{$\begin{array}{l}\text { Ciclos planejados: } 1,2 \text { e } 3 \text { de acordo com ciclos de aplicaçăo do } \\
\text { método de Pedroso, 2018. } \\
\text { Ciclos realizados: 1, 2, } 3 \text { e } 4 \text { por ter ocorrido pivotagem (etapa 12) no } \\
\text { decorrer do processo. }\end{array}$} & $\begin{array}{l}\text { - Foram realizados os ciclos } 1,2,3 \text { e } 4 \text { na } \\
\text { construçăo de modelos de negócios em uma } \\
\text { startup de biotecnologia no mercado brasileiro, a } \\
\text { Sampa Tech. Devido a pivotagem no ciclo } 3 \\
\text { previsto na avaliação econômica. } \\
\text { - A pesquisadora sugeriu adequacōes no método } \\
\text { descrito por Pedroso, } 2018 \text { para aplicaçäo em } \\
\text { startups de biotecnologia. }\end{array}$ \\
\hline
\end{tabular}

Figura 61: Conclusões resumidas do trabalho (Fonte: a autora).

\subsection{Contribuições da pesquisa}

A pesquisadora por meio desse estudo identificou os métodos para a construção de modelos de negócios em empresa startup fundamentada em inovação. A revisão bibliográfica apontou seis processos de construção de modelo de negócios que a pesquisadora entende como relevantes. Dentre esses modelos relatados no capítulo 4, dois são aplicáveis a startups dirigidas por inovação que são os descritos por Aulet, 2013 e Pedroso, 2018.

O método de construção de modelo de negócios descrito por Pedroso, 2018 foi selecionado para compor a intervenção em empresa startup de biotecnologia. A seleção para esse método foi realizada por razão de corresponder a resultado em modelo de negócios em mais diversas dimensões compreendendo modelo de gestão e modelo de inovação.

A aplicação do método de construção de modelo de negócios foi realizado em uma empresa startup brasileira de biotecnologia no mercado brasileiro, a Sampa Tech. O capítulo 6 relata e discute os resultados em detalhes. Vale apontar que a startup já está na fase de execução de seu modelo de negócios e não na fase de concepção.

O método aplicado foi eficaz para revisar o modelo de negócios no ponto de vista de sua concepção como também para validar seu modelo de negócios em execução por sua fundamentação do processo de descoberta de clientes.

Durante a construção do modelo de negócios a empresa se viu perante mudanças no produto visto que o desenvolvimento do mesmo abriu possibilidades de uma plataforma. 
O aprendizado mostrou outras oportunidades de mercado, tais como alimentos, agroindústria, etc, e outra plataforma de tecnologia associadas a POC. O que tornou um desafio a seleção da melhor alternativa.

O aprendizado mostrou outras oportunidades de mercado, tais como alimentos, agroindústria, etc, e outra plataforma de tecnologia associadas a POC. O que tornou um desafio a seleção da melhor alternativa.

\subsection{Limitações da pesquisa}

Uma limitação do estudo foi a intervenção em uma startup de biotecnologia early stage em fase de execução para revisão de seu modelo de negócios o que pode resultar em desvio na generalização das conclusões para a generalização da eficácia da utilização desse método para startups de biotecnologia não early stage para definição de modelos de negócios inicial.

Ainda, outra limitação do estudo foi a intervenção em uma startup de biotecnologia brasileira somente o que pode resultar em desvio na generalização das conclusões para a generalização da eficácia da utilização desse método para startups em outros territórios.

\subsection{Considerações finais e pesquisas futuras}

A pesquisadora vislumbra a oportunidade de pesquisas futuras na intervenção de outros tipos de startup com fundamentação em inovação com o objetivo de estabelecer a utilização do mesmo em startups desse tipo uma vez que há grande necessidade de processos de construção de modelo de negócios nesse âmbito.

Ainda, a pesquisadora acredita que há a oportunidade da exploração dos determinantes que diferenciam as startups a nível global e o impacto na construção do modelo de negócios 


\section{REFERÊNCIAS BIBLIOGRÁFICAS}

Agarwal, A. (2002). Do companion diagnostics make economic sense for drug developers? Nature Biotechnology, 29 (6), 695-708.

Aulet, B. (2013). Disciplined entrepreneurship: 24 steps to a successful startup. Hoboken: John Wiley \& Sons.

Bardin, L. (2008). Análise de conteúdo. Lisboa: Edições 70.

Bartholomew, S. (1997). National systems of biotechnology innovation: complex interdependence in the global system. Journal of International Business Studies, 28 (2), 241-266.

Birkinshaw, J., \& Goddard, J. (2009). What is your management model? MIT Sloan Management Review, 50 (2), 81-90.

Blank, S., \& Dorf, B. (2012). The startup owner's manual: The step-by-step guide for building a great company. Pescadero, California: K\&S Ranch.

Bryman, A. (2003). Research methods and organization studies. Abingdon: Routledge.

Carlson, R. (2016). Estimating the biotech sector's contribution to the US economy. Nature Biotechnology, 34 (3), 247-255.

Coghlan, D., \& Brannick, T. (2014). Doing action research in your own organization. Thousand Oaks: Sage Publishing.

Coughlan, P., \& Coghlan, D. (2002). Action research for operations management. International Journal of Operations \& Production Management, 22 (2), 220-240.

Cooperrider, D. L., \& Srivastva, S. (1987). Appreciative inquiry in organizational life. In Woodman, R., \& Pasmore, W., Research in Organizational Change and Development, Greenwich, Connecticut and London, England: Jai Press, 1, 129-169.

Driessen, M. P., \& Zwart, P. S. (2007). The entrepreneur scan measuring characteristics and traits of entrepreneurs. Recuperado em 01 de Junho, 2016, de http://www.necarbo.eu/files/E-scan\% 20MAB\% 20Article. pdf.

Drucker, P. F. (1994). The Theory of the Business. Harvard Business Review, 72 (5), 95 104.

Esteves, T. M. B., Daumas, R. P., Oliveira, M. I. C. D., Andrade, C. A. A. F. D., \& Leite, I. C. (2014). Fatores associados à amamentação na primeira hora de vida: revisão sistemática. Rev Saúde Pública, 48 (4), 697-703.

Fisken, J., \& Rutherford, J. (2002). Business models and investment trends in the biotechnology industry in Europe. Journal of Commercial Biotechnology, 8 (3), 191-199. 
Furr, N. R., \& Dyer, J. (2014). The innovator's method: Bringing the lean startup into your organization. Boston: Harvard Business Press.

Gassmann, O., Frankenberger, K., \& Csik, M. (2014). The business model navigator: 55 models that will revolutionize your business. London: Pearson UK.

Gil, A. C. (2002). Como elaborar projetos de pesquisa. São Paulo: Atlas.

Lijphart, A. (1971). Comparative politics and the comparative method. American Political Science Review, 65 (3), 682-693.

Gummesson, E. (2000). Qualitative Methods in Management Research. Thousand Oaks: Sage Publishing.

Hoopes, L. (2008). Introduction to the gene expression and regulation topic room. Nature Education, 1 (1), 160.

Kurtzman, G. (2005). A Business Model for Diagnostic Startups-A Business Model for a New Generation Of Diagnostics Companies. Biotechnology Healthcare, 2 (5), 50-55.

Lehoux, P, Daudelin, G, Williams-Jones, B, Denis, J.-L \& Longo, C. (2014). How do business model and health technology design influence each other? Insights from a longitudinal case study of three academic spin-offs. Research Policy 43, 1025-1038.

Lewin, K. (1947). Group decision and social change. In Lewin, K, \& Gold, M. The Complete Social Scientist: A Kurt Lewin Reader. Washington, DC: American Psychological Association, 265-84.

Lijphart, A. (1971). Comparative politics and the comparative method. American Political Science Review, 65 (3), 682-693.

Magretta, J. (2002). Why business models matter. Harvard Business Review, 80 (5), 86-92.

Martins, G., \& Theóphilo, C. R. (2009). Metodologia da investigação cientifica. São Paulo: Atlas.

Maurya, A. (2012). Running lean: iterate from plan A to a plan that works. Sebastopol: O'Reilly Media.

Mello, C. H. P., Turrioni, J. B., Xavier, A. F., \& Campos, D. F. (2012). Pesquisa-ação na engenharia de produção: proposta de estruturação para sua condução. Production, 22 (1), $1-13$.

Miller, Z. (2014). Investing in the Future of Medicine: A Investor's Guide to the In Vitro Diagnostics Market. Recuperado em 01 de Julho, 2016, de https://www.forbes.com/sites/zackmiller/2014/02/12/investing-in-the-future-of-medicinea-investors-guide-to-the-in-vitro-diagnostics market/\#6ccde5b11da5. 
Massachusetts Institute of Technology [MIT] (2017). 50 Smartest Companies 2017. Recuperado em 10 de Novembro de 2018, de https://www.technologyreview.com/lists/companies/2017.

Morris, M., Schindehutteb, M. \& Allen, J. (2005). The entrepreneur's business model: toward a unified perspective. Journal of Business Research 58, 726-735.

Nosella, A., Petroni, G., \& Verbano, C. (2006). How do Italian biotechnology startups survive? Journal of Business Chemistry, 3 (2), 7-14.

Osterwalder, A., \& Pigneur, Y. (2010). Business model generation: a handbook for visionaries, game changers, and challengers. Hoboken: John Wiley \& Sons.

Osterwalder, A., Pigneur, Y., Bernarda, G., \& Smith, A. (2014). Value proposition design: How to create products and services customers want. Hoboken: John Wiley \& Sons.

Ries, E. (2011). The lean startup: How today's entrepreneurs use continuous innovation to create radically successful businesses. New York: Crown Business.

Pedroso, M. C. (2016). Modelo de negócios e suas aplicações em administração. Tese de livre docência, Faculdade de Economia, Administração e Contabilidade, Universidade de São Paulo. São Paulo, Brazil.

Pedroso, M. C. (2017). Modelo de negócios: análise, concepção e inovação [Notas de aula da disciplina]. Faculdade de Economia, Administração e Contabilidade, Universidade de São Paulo. São Paulo, Brazil.

Pedroso, M. C. (2018). Laboratório de Inovação [Notas de aula da disciplina]. Faculdade de Economia, Administração e Contabilidade, Universidade de São Paulo. São Paulo, Brazil.

Pisano, G. P. (2006). Can Science Be a Business? Lessons from Biotech. Harvard Business Review, 10, 1-12.

Ravishankar, D. (2014). IVD TRENDS - In Vitro Diagnostics Players Go Global as US \& Europe Markets Slow Down. Recuperado em 01 de julho, 2017, de http://www.drugdev.com/Uploads/Public/Nov\%20Dec\%202014\%20WEB\%20FRIENDLY.pdf.

Reason, P., \& Bradbury, H. (2001). Handbook of action research: Participative inquiry and practice. Thousand Oaks: Sage Publishing.

Rhyne, L. C. (2009). Business model design for biotechnology firms. International Journal of Business Innovation and Research, 3 (3), 298-310.

Sabatier, V, Mangematin, V, \& Rousselle, T. (2010). From Recipe to Dinner: Business Model Portfolios in the European Biopharmaceutical Industry. Long Range Planning 43, 431-447. 
Shani, A. B., \& Pasmore, W. A. (1985). Organization inquiry: Towards a new model of the action research process. In Warrick, D. D., Contemporary Organization development: Current Thinking and Aplications, Glenview: Scott Foresman, 438-448.

Shields, D., \& Dhabale, S. (2014). World DNA Diagnostics Market - Opportunities and Forecasts, 2013-2020. Recuperado em 01 de julho, 2016, de www.alliedmarketresearch.com/DNA-diagnostics-market.

Tölle, J., \& Kappfjell Herbst, F. (2016). The Business Model of Biotech SMEs: How do biotech SMEs cope with the industry's challenges? Dissertação (Mestrado), Faculdade de Ciências Sociais, Umeå University, Umeå, Suécia.

Tsai, W., \& Erickson, S. (2006). Early-stage biotech companies: Strategies for survival and growth. Biotechnology healthcare, 3 (3), 49-53.

Zikmund, W. G., Babin, B. J., Carr, J. C., \& Griffin, M. (2013). Business research methods. South-Western: Cengage Learning. 